Portland State University

PDXScholar

$1-1-1984$

\title{
An investigation of the relationship between biographical characteristics and job satisfaction among middle school teachers in four suburban school districts
}

Susan Scott-Miller

Portland State University

Follow this and additional works at: https://pdxscholar.library.pdx.edu/open_access_etds Let us know how access to this document benefits you.

\section{Recommended Citation}

Scott-Miller, Susan, "An investigation of the relationship between biographical characteristics and job satisfaction among middle school teachers in four suburban school districts" (1984). Dissertations and Theses. Paper 405.

https://doi.org/10.15760/etd.405

This Dissertation is brought to you for free and open access. It has been accepted for inclusion in Dissertations and Theses by an authorized administrator of PDXScholar. Please contact us if we can make this document more accessible: pdxscholar@pdx.edu. 


\title{
AN INVESTIGATION OF THE RELATIONSHIP BETWEEN BIOGRAPHICAL CHARACTERISTICS AND JOB SATISFACTION AMONG MIDDLE SCHOOL TEACHERS IN FOUR SUBURBAN SCHOOL DISTRICTS
}

\author{
By \\ SUSAN SCOTT-MILLER
}

A dissertation submitted in partial fulfiliment of the requirements for the degree of

\author{
DOCTOR OF EDUCATION \\ in
}

PUBLIC SCHOOL ADMINISTRATION AND SUPERVISION

Portland State University

The University of Oregon

- 1984 Susan Scott-Miller 
TO THE OFFICE OF GRADUATE STUDIES AND RESEARCH:

The members of the Committee approve the dissertation of Susan Scott-Miller presented November 15, 1984.

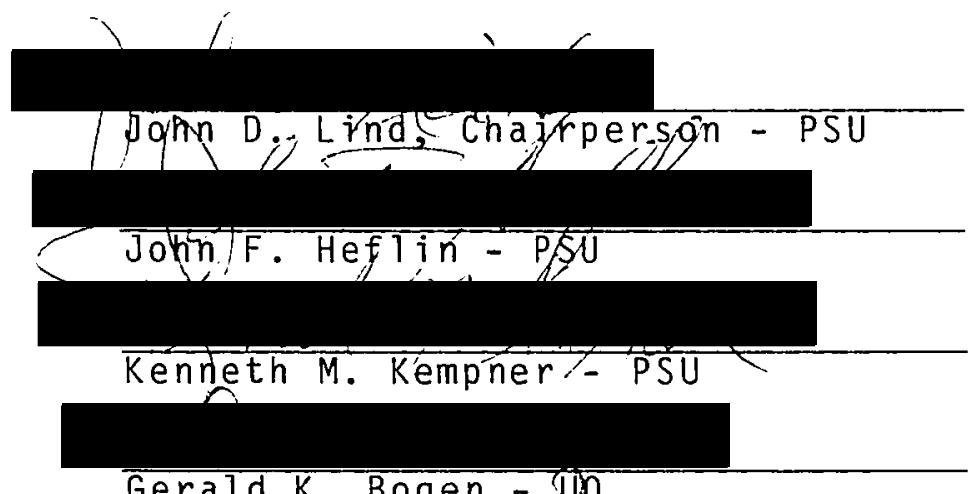

Gerald K. Bogen - Uto

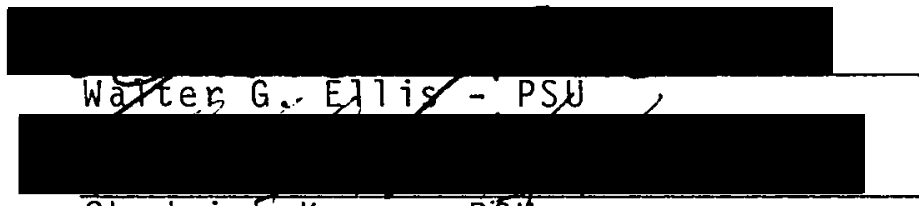

Chadwick Karr - PSD

APPROMEQ:

George V. Guy, Bi-Univergity Program Coordinator (Portiand State University)

Richard A. Schmuck, Bi-University Program Coordinator (University of Oregon)

Donald J. Leu sean? $8 f$ the School of Education (Portland State unjyersityd

Jim F. He (éath, Dean of Graduate Studies and Research (Portladd State University) 
AN ABSTRACT OF THE DISSERTATION OF Susan Scott-Miller for the Doctor of Education in Public School Administration and Supervision presented November 15, 1984.

Title: An Investigation of the Relationship Between Biographical Characteristics and Job Satisfaction Among Middle School Teachers in Four Suburban School Districts APPROVED BY MEMBERS OF THE DISSERTATION COMMITTEE:
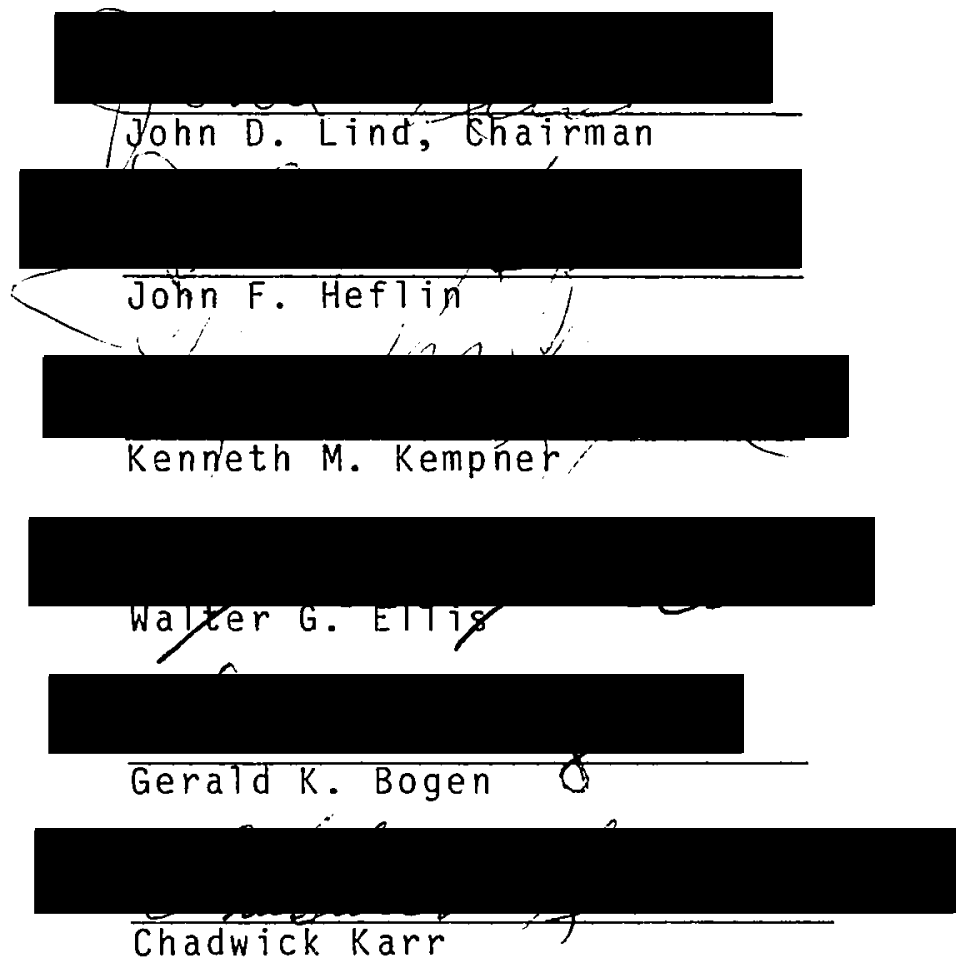

A descriptive study was conducted to examine the status of middle school teachers in four suburban school districts. The dependent variables that were studied included the extent of satisfaction with teaching demonstrated by the 
teachers, the rapport that the teachers demonstrated with their principals and other staff members, and the selfperceived feelings of status felt by the teachers.

Eight hypotheses were formulated and centered around changes in job satisfaction based upon biographical descriptors such as age, career stage, certification level, and gender. In addition to the questionnaire (The Purdue Teacher opinionaire) completed by the teachers, an interview was conducted with the principal of each school in the study. These data were also compared to the levels of satisfaction with teaching that were measured in the teachers. Two areas of inquiry in the interview were a self-perceived management style and the level of implementation of middle school characteristics as delineated by Riegle (1971).

It was concluded that gender was significantly related to the extent of satisfaction with teaching reported by the middle school teachers. In support of the work done by Greenfield and Blase (1981), it was found that the middle school teachers, like the secondary teacher in the 1981 study, manifested a unique pattern of satisfaction with their jobs over the career stages as outlined by Gould (1979). This pattern differs from the patterns demonstrated by research for other professions and supports the findings of Greenfield and Blase (1981) and Lortie (1975). Greater dissatisfaction with teaching was indicated in the first three years than at any other time during the teaching career. 


\section{ACKNOWLEDGEMENTS}

There are many people who have provided support to me throughout the process that has lead to this achievement on my part. It is to many of these people that a part of this belongs. To Dealous Cox goes the credit for mentorship and professional support, to Earl Anderson the acknowledgement for good-humored encouragement and honest, straight forward advice when needed. To my academic advisors John Lind, John Heflin, Ken Kempner, Walter Ellis, and Jerry Bogen my thanks for support and advice in their areas of expertise. To Pati Sluys thanks for work above and beyond the call of duty.

To my family and a few close friends goes acknowledgement of their loving tolerance of the pressures and deprivations that have been the product of my obsession. My thanks to Dorothea Scott Kucera, Billie G. Miller, Charlotte and Mike Morris, and Tom, ickey, and Michael Cocks.

Finally, I acknowledge the silent fortitude of my husband Russ Miller who has maintained his sanity and my own and continued to take pride in my achievements while quietiy sacrificing his own needs so that I might meet my goals. I hope someday to be able to achieve what he already possesses. 
TABLE OF CONTENTS

PAGE

ACKNOWLEDGEMENTS . . . . . . . . . . . . . . . . . . . . .

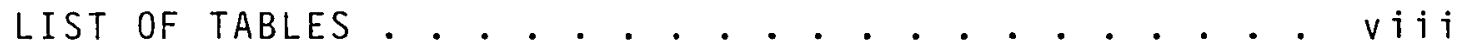

LIST OF FIGURES. • . . . . . . . . . . . . . . . . . xii

CHAPTER

I INTRODUCTION

Statement of the Problem. . . . . . . 5

Hypotheses. . . . . . . . . . . 8

Importance of the Study . . . . . . . 11

Delimitations of the Study. . . . . . . 12

Definition of Terms . . . . . . . . 12

Summary . • . . . . . . . . . . . 14

I I REVIEW OF THE LITERATURE. . . . . . . . . . . 16

Job Satisfaction. . . . . . . . . 16

Hierarchies of Needs . . . . . . . . . 17

From Need Fulfillment to Social

Information Theory. . . . . . . . . . 19

Nature of the Job and Job Satisfaction. . 28

Job Satisfaction and Supervision. . . . 30

other Related Factors and Job

Satisfaction... . . . . . . . . 30

Morale and Job Satisfaction... . . . 34

Job Satisfaction and Teaching . . . . . 35 
Career Stages... . . . . . . . . .

Job Satisfaction and Training for Middle Middle School Teachers. . . . . . . 43

Job Satisfaction and the Middle School. . 48

Middle School Characteristics... . . 50

II I GENERAL METHODOLOGICAL DESIGN . . . . . . . . 56

Introduction. . . . . . . . . . . 56

Design of the Investigation . . . . . 57

Instrumentation . . . . . . . . 59

Data Gathering Procedures . . . . . 65

Statistical Mithodology . . . . . . 67

Classification of Management Styles.. . 68

Summary . . . . . . . . . . . . 68

iV PRESENTATION OF THE FINDINGS. . . . . . . . . . . 70

Sample. . . . . . . . . . . . . 70

Size

Respondents

Descriptions

Results of the PTO............

Scoring of the PTO

Summary of the Results for the Total

Sample... . . . . . . . . . .

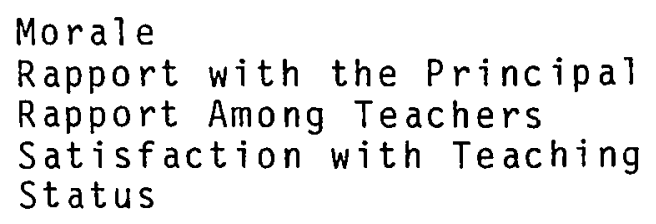


School 2

School 3

School 4

School 5

School 6

School 7

School 8

School 9

Summary of Results by School and

District for Satisfaction with

Teaching and Morale

Relationship of PTO Subscales and

Biographical Data......... 104

Satisfaction with Teaching

Rapport with the Principal. . . . . . 118

Relationship to Gender

Relationship to Each School

Relationship to Age

Rapport Among Teachers. . . . . . . . 132

Relationship with Gender

Relationship to District of the Respondent

Relationship to School of the Respondent

Comparison to PTO Norms

Relationship to Teacher Status Subscale. 135

Certification

Morale. . . . . . . . . . . . 137

Gender

Age

Administrators' Questionnaire... . . 141

Further Findings of the Adminisstrators' Questionnaire

Summary

$\checkmark$ SUMMARY, CONCLUSIONS, AND RECOMMENDATIONS • $\quad 147$

Summary . . . . . . . . . . . . 147 
Conclusion. . . . . . . . . . . . . .

Satisfaction with Teaching

Rapport with the Principal

Rapport Among Teachers

Teacher Status

Morale

Age

Limitations of the Study. . . . . . . .

160

Geographic Locations

Historical Events

Subjectivity of Administrators' Questionnaire

Additional Contributing Independent. . .

Variable

Implications of the Study . . . . . . 161

Recommendations for Further Research. . . 163

BIBLIOGRAPHY . . . . . . . . . . . . . . . . . . . . 165

APPENDIX A

APPENDIX B . . . . . . . . . . . . . . . . . . . . . 196 


\section{LIST OF TABLES}

TABLE

PAGE

I Percent of Institutions offering

Selected Courses/Experiences.....

I Dependent and Independent Variables...

II Coefficients Alpha for PTO. . . . . .

IV Inter-factor Correlations of the PTO. . .

$V$ Percentile Distribution of Faculty Score Medians by Factors........... . . 62

VI Numbering of Schools and Districts. . . 67

VII Characteristics of Sample Schools and Number of Respondents.......

VIII Distribution of Respondents by School..

IX Distribution of Respondents by District.

$x$ Distribution of Respondents by Grade Level Taught.............

XI Frequency Distribution by Gender. . . .

XII Distribution of Respondents by Age. . .

XIII Distribution of Respondents by

Subject Area Taught. . . . . . . . .

XIV Frequency Distribution by Number of Years Taught. . . . . . . . .

XV Frequency Distribution by Years in

Present Position . . . . . . . . . .

XVI Frequency Distribution by Certification. . 
TABLE

PAGE

XVIII Frequency of Respondents Who Are

Graduate of Oregon Institutions. . . .

XIX Frequency Distribution by Middle School Training. . . . . . . . . . 84

$X X$ Assignment of PTO Items to Subscales... . 86

XXI Results for the Total Sample on the Scales of the PTO........... . 89

XXII Results for School 1 on Select Scale of the PTO . . . . . . . . . . . 91

XXIII Results for School 2 on select Scales of the PTO .............. . . 92

XXIV Results for Schoo? 3 on Select Scales of the PTO . . . . . . . . . . . 93

XXV Results for School 4 on Select Scales of the PTO . . . . . . . . . . . . 94

XXVI Results for School 5 on Select Scales of the PTO . . . . . . . . . . . . 95

XXVII Results for School 6 on Select Scales of the PTO . . . . . . . . . . . 96

XXVIII Results for School 7 on Select Scales of the PTO...............

XXIX Results for School 8 on select Scales of the PTO . . . . . . . . . . . . 98

XXX Results for School 9 on Select Scales of the PTO . . . . . . . . . . . .

XXXI Satisfaction with Teaching Scores by District. . . . . . . . . . . . 100

XXXII Satisfaction with Teaching Scores by School............... 100

XXXII Morale Scores by District. . . . . . . . 103 XXXIV Morale Scores by Schools......... 104 XXXV Distribution of Gender by School . . . . . 107 
TABLE

PAGE

XXXVI Levels of Satisfaction by Gender..... . 108

XXXVII ANOVA for Satisfaction with Teaching and Gender............ . . 110

XXXVIII The Level of Satisfaction with

Teaching by the Age. . . . . . . . 111

XXXIX Level of Satisfaction with Teaching

by Years Taught. . . . . . . . . . 114

XL Level of Satisfaction with Teaching

by Certification......... . 114

XLI Level of Satisfaction with Teaching Medians................ . . 116

XLII Level of Rapport with the Principal by the Gender of the Respondent. . . . 118

XLII ANOVA of the Subscale Rapport with the Principal and the Gender of the Respondent . . . . . . . . . . 119

XLIV Mean Scores for Rapport with the Principal by School. . . . . . . . . 121

XLV ANOVA of the Subscale Rapport with Principal with the School of the Respondent . . . . . . . . . . . . .

XLVI Management Style and Mean Rapport with Principal Score............ 128

XLVII ANOVA of the Subscale Rapport with the Principal Selected by the Age of the Respondent . . . . . . . . . . . 129

XLVIII Rapport with Principal . . . . . . . . . 130

LXIX ANOVA of the Subscale Rapport Among Teachers with the District of the Respondent . . . . . . . . . . . .

$L$ ANOVA of the Subscale Rapport Among Teachers with the School of the Respondent . . . . . . . . . . . 133

LI Rapport Among Teachers . . . . . . . . 135 
LII Teacher Status . . . . . . . . . . 137

LIII Total PTO Scale Scores for Morale by Gender............... 138

LIV ANOVA for Morale and Gender of Respondent by School........ . 138

LV Morale by District............. 139

LVI ANOVA for Morale and Gender of Respondent by District. . . . . . . 139

LVII Mean Morale Score for Gould's Career Stages............ . 140

LVIII ANOVA of Morale Scale with the
District of the Respondent . . . . . 140

LVIX ANOVA of Morale Scale with the School of the Respondents....... 140

LX Rankings by Principals of Middle School Characteristics........ 143

LXI Mean Levels of School Implementation of Middle School Characteristics... .

LXII Means and Standard Deviations for Test and Retest Aciiiinistration of the PTO . . 195

LXII Inter-factor Correlations. . . . . . . . 198

LXIV Scores of Schools on Remaining Subscales of $\mathrm{PTO}$. . . . . . . . . . . . . . 199

LXV Means for Each School by Factor. . . . . . 200

LXVI Medians for Each School by Factor. . . . . 201

LXVII Percentage Distribution of Faculty Medians by Factors in the Normative Sample.. . 202

LXVIII Faculty Medians for the Sample by Factors. . 203

LXIX Teacher Salary Medians in Relation to Normat ive Sample........ . . 204 
LXX Teacher Load Medians in Relation to Normative Sample......... 206

LXXI Curriculum Issues Medians in Relation to Normative Sample... . . . . . . 208

LXXII Community Support for Education Medians in Relation to Normative Sample... . . 210

LXXIII School Facilities and Services Medians

in Relation to Normative Sample. . . . 212

LXXIV Community Pressures Medians in Relation to Normative Sample... . . . . . 214 


\section{LIST OF FIGURES}

F I GURE

PAGE

1. Hierarchies of Needs . . . . . . . . . . 18

2. The Relationship of Extrinsic and Intrinsic

Rewards to Job Satisfaction and Perceived

Equitability............... . . 26

3. Mean Satisfaction with Teaching by District. . . 101

4. Mean Satisfaction with Teaching by School. . . 102

5. Mean Morale by District. . . . . . . . 105

6. Mean Morale Score by School. . . . . . . . 106

7. Level of Satisfaction with Teaching by Gender. . 109

8. Mean Satisfaction with Teaching by Age of the Respondent . . . . . . . . . . . . 112

9. Mean Satisfaction with Teaching by Years

Taught by Respondents............. 115

10. Median Satisfaction with Teaching Responses

by Item. . . . . . . . . . . . . . . 117

11. Mean Rapport with the Principal by Gender
of the Respondent. . . . . . . . . . 120

12. Median Rapport with Principal Scores by Item . 131

13. Median Rapport Among Teachers Scores by Item . 134

14. Median Teacher Status Scores by Item . . . . 136

15. Study Calendar . . . . . . . . . . . . 194

16. Median Teacher Salary Responses by Item. . . . 205

17. Median Teacher Load Responses by Item. . . . . 207 
18. Median Curriculum Issues Responses by Item. . . 209

19. Median Community Support for Education

$$
\text { Responses by Item. . . . . . . . . . . . . } 211
$$

20. Median School Facilities and Services

Responses by Item. . . . . . . . . . . 213

21. Median Community Pressure Responses by Item. . 215 
CHAPTER I

\section{INTRODUCTION}

The last twenty five years have given rise to an educational trend called the middle school movement. Involved in this movement is the revival of the historical basis of the development of the junior high school; namely provision for a specialized program for the education of middle grade students. Although the initial reasons for the roots of the two movements differ, both have similar aims. Specifically, the middle school movement is concerned with ". . providing effective educational experiences for youth in the middle years" (Lounsbury \& Vars, 1980, pp. xi-xii).

Some states have recognized this movement by requiring teacher certification aimed specifically at this level of education. Florida is one such state. The state of oregon presentiy requires that middle school teachers be certified to teach either at the secondary level or at the elementary level with endorsements to qualify for specific subject areas at the middle school level. There is no middle school certification per se in oregon. This means that there may be teachers employed at the middle school level who have been prepared to teach in grade levels from kindergarten through the twe lfth grade. 
The last two decades have seen enormous growth in the number of middle schools, and further growth of the concept of the middle school, as opposed to the more traditional format of elementary, junior high, and/or senior high. In the fall of 1976 there were approximately 5,000 middle schools established nationwide (George \& McEwin, 1978), while by 1983 this number had grown to approximately 12,000 (McEwin, 1983). Such rapid growtr outstrips the development attributed to junior high schools in the 1920's (1925 - 254 junior highs; 1934 - 1,948 junior highs) (Lounsbury \& Vars, 1980). Professional organizations have grown up around the movement with the most successful being the National Middle School Association which was formed in 1974. This association publishes a quarterly journal, provides an annual national conference, and has state and regional affiliates (Lounsbury \& Vars, 1980).

There has been a general lack of institutional recognition of the middle school movement. Throughout the increasing proliferation of schools claiming the title of middle school, there has been an attendant push to devise a middle school teacher training and certification requirement. Some educators have seen this as a necessity, "For more than twenty five years the literature..." has been full of articles which decry the lack of training for teachers in middle school education (George \& McEwin, 1978, p. 13). Others have advocated the balance between those 
teachers with an elementary and a secondary certification. It would seem that there are as many philosophical positions as there are "experts" in the field of middle school education. The question, however, has always focused on the needs of students. This focus is based on the assumption that meeting the needs of students is done through training teachers in a specific way. Little attention has been paid to the effect that this lack of professional certification and training has had on the perceived status, satisfaction and morale of the teachers at this middle level of education. There may be a significant negative impact on the fulfillment of educational goals at the middle school level because of ". . . the absence of middle level certification and resulting lack of status associated with a career at the middle level" (MCEwin, 1983, p. 80). In addition, it may be assumed that there are some unique characteristics about these teachers and the skills they have which are not being addressed through the institutional preparation that they receive. Such lack of preparation may influence their levels of morale and job satisfaction. This decreased status and lowered levels of satisfaction and morale may influence negatively the quality of education for middle school students.

Dealing with the reality of this situation in the State of Oregon forces the middle school level teacher to be certified at either the elementary level, and carry 
endorsements to teach specific subject areas, or be certified at the secondary level. The teacher must then make a choice to teach at the middle school level without any or the scantiest of training. This leads to the possibility that job satisfaction may be connected to the training, experiential background and/or career stage of the middle school teachers. This study attempts to look at that possibility. Specifically, this study relates the levels of morale, job satisfaction, status and other factors measured by the Purdue Teaching Opinionaire (PTO) to the levels of certification, experiential background, career stages, and other biographical data for the teachers who are presently employed as middle school teachers in the state of oregon. The study is limited to those teachers who are employed by districts that fit into defined parameters including location, attending population, and size.

In a study done by DeMedio (1980) it was found that middle school teachers saw a real need for specific certification for teaching at the middle level. Secondary teachers simultaneously saw a need for the certification. Those professionals who are actively involved in middle school educational programs saw a significant reason for the existence of certification for that level while the need has been ignored by many of the certifying agencies in the United States. In a 1968 study done by Pumerantz, there was no alteration in state department attitudes about middle school 
education, but a similar study in 1975 showed some trend toward the development of middle school certification requirements (George, MCMillan, Malinka, \& Pumerantz, 1975).

The problem has one more complicating factor that must be addressed. The simple application of the name "middle school" to a school may not be theoretically valid. Many districts have used the term middle school since the late 1960's while actively employing what has come to be called a junior high curricular program. By definition a junior high program would be one that is just that; a junior, high school. The programs would include departmentalized structure with department heads, interscholastic sports and all of the support systems for those sports, little or no interdisciplinary teaming, and specific Carnegie unit requirements that must be filled by every student regardless of that student's individual needs.

Since the name does not a middle school make, it has been necessary for this study to determine the extent of implementation of middle school principles in the schools which participate in the study. The degree of implementation may also influence levels of satisfaction, morale, and status of the teachers (Pook, 1981).

\section{Statement of the Problem}

This study investigated the relationship between the levels of various factors including job satisfaction, 
rapport, status, and morale of teachers at the middle school level and the experiential background, certification, specific job characteristics, and other biographical data of the teachers.

Three separate instruments have been used to collect the data for analysis of the teachers and schools:

1. The PTO was the primary instrument to be used with the teachers. This instrument was administered to all teacher participants;

2. A biographical questionnaire that consisted of no more than one page of questions pertaining to the individual teacher's work and educational experience, level of certification and personal data;

3. An interview of each administrator of the schools included in the sample determined the extent of implementation of middle school concepts, administrative philosphy as self-perceived, and other descriptive data.

The collected data were analyzed by comparing the scales as obtained from the PTO to the information obtained from the other two instruments.

1. Comparison of the biographical characteristics of the teachers to the levels of morale, job satisfaction, and other subscales about the teachers as measured by the PTO. 
2. Analysis of the levels of implementation of middle school principles as compared to the levels of the various factors measured by the PTO.

3. An analysis of the relationship of the subscales of the PTO for this sample.

When comparing the biographical data of the teachers to their scores on the PTO it was necessary to look at a number of areas:

1. Is there a relationship between the gender of teacher and the levels of satisfaction?

2. Is there a relationship between the level of certification of the teacher and the levels of satisfaction and morale obtained?

3. Is there a relationship between the career stage of the teacher and the level of job satisfaction and morale?

4. Is there a relationship between the first three years of teaching and the levels of job satisfaction?

5. Is there a relationship between gender of the teacher and scores on the subscales of Rapport with Administrator and Rapport with other Teachers?

6. Is there a relationship between the scores on the subscale of Rapport with Administrator and the self-perceived management style of the administrator? 
7. Is there a relationship between the certification level of the teacher and the perceived level of stati:s as measured by the PTO?

8. Is there a relationship between the occurrence of teacher labor problems in the last five years and the levels of job satisfaction and morale among teachers?

9. Is there a relationship between the existence of major budgetary problems in the district and the levels of satisfaction with the job and salary as measured by the PTO?

\section{Hypotheses}

It was hypothesized that there would be a relationship between the levels of satisfaction and the number of years of experience in teaching at the middle school level. This relationship was based on the same relationship that has been found to exist among teachers at the secondary level. Hypothesis 1: Those teachers in the first three years of teaching will have a lower score on the subscale score Satisfaction with Teaching than teachers in other experiential levels. Specifically, the experiential levels addressed are:

1. $1-3$ years;

2. 4-14 years; and

3. 16-highest years. 
It was further hypothesized that there would be a relationship between the level of certification of the teacher and the score for morale and the subscale score for Job satisfaction.

Hypothesis 2: Those teachers possessing certification at the elementary level will have higher subscale scores in Satisfaction with Teaching at schools having higher levels of implementation of the eighteen characteristics of middle schools. Hypothesis 3: In the initial years of their careers, middle school teachers will have lowered scores on the subscale Satisfaction with Teaching (ages 22 to 30 years) followed by increased scores through the next career stage (ages 31 to 44 years), and, finally, lowered scores during the remaining years of their careers (ages 45 to 65 years).

This pattern reflected the findings among secondary teachers (Greenfield \& Blase, 1981).

Based on the work of Charters (1970) and Lortie (1975) it was hypothesized that there would be a relationship between the gender of the respondents and the levels of job satisfaction.

Hypothesis 4: Females in the sample will have higher scores on the subscale Satisfaction with Teaching than males. 
In addition, other of the subscales were assumed to have a relationship to the gender of the respondents.

Hypothesis 5: Females will have higher scores on the subscales relating to levels of rapport (Rapport with the Principal and Rapport Among Teachers).

In part, this relationship is based on the postulate that the higher levels of satisfaction are related to these levels of rapport.

It was also postulated that the closer the principal's management style was to a participatory management style the higher would be the levels of teacher satisfaction and morale in the school. If the principal indicated a greater tendency toward a high task and low relationship style of management, the lower the levels of Satisfaction with Teaching and Rapport with the Principal demonstrated by the teachers in that particular building.

Hypothesis 6: The levels of Satisfaction with Teaching, as determined by the scores on the PTO, will be lower in buildings where the principal has indicated a higher task orientation and less relationship orientation in his/her self-perceived management style analysis.

Hypothesis 7: Middle school teachers will demonstrate scores below the 50 th percentile of the norming sample on the subscale Teacher Status.

Hypothesis 8: Districts which have suffered labor 
relations problems over the past five years will demonstrate lower scores on the Morale scale and the subscale for Satisfaction with Teaching.

\section{Importance of the study}

Since there is a call by some experts for recognition of the difference between the middle school and other organizational structures for students in the middle years and, along with this, recognition of the need to train and hire teachers specifically for middle schools, it is important to study whether these differences can be supported by looking at the status of the individuals who are, at present, successfully participating as teachers at this level.

This study is an investigation of the status of middle school teachers and a description of the characteristics of middle school teachers in middle schools suburban to a large metropolitan area in the Northwestern United States:. The additional information gathered through this study will provide a fuller picture of the individuals who are presently members of the teaching profession at the middle school level. It is important to note that the information that is available which relates specifically to middle school teachers is somewhat limited in scope and quantity. It is hoped that this study will add to this knowledge base about those special individuals who have chosen to teach the tranescent child. 
Delimitations of the Study

This study possesses some important delimiters that must be remembered. The school districts involved in this study were suburban to a large metropolitan area in the Northwestern United States. The districts were chosen for a number of commonalities that all possessed:

1. Predominantly white student populations;

2. No more than three but no less than two middle schools in the district as a whole;

3. School populations that did not exceed 1,000 students; and

4. All schools were termed "middle schooi" in the school name.

\section{Definition of Terms}

The PTO inciudes several factors which are defined below:

Satisfaction

With Teaching: (Job Satisfaction) Feelings of
satisfaction with teaching. The
satisfied teacher loves to
teach, feels competent in his/
her job, enjoys his/her stu-
dents, and believes in the fu-
ture of teaching as an occupa-
tion.


Rapport with the

Principal:

Rapport Among

Teachers:

Teacher Status:

Morale:
Teacher's feelings about the principal -- his/her professional competency, interest in teachers and their work, ability to communicate, and skill in human relations.

The teacher's relationship with other teachers. The teacher's opinions about the cooperation, preparation, ethics, influence, interests, and competency of his/her peers.

The teacher's feelings about the prestige, security, and benefits afforded teaching.

The extent to which an individual's needs are satisfied and he/she perceives the satisfaction as stemming from the total job situation. High morale is evident when there is interest in and enthusiasm for the job. The important element here is what the person believes and 
feels, not the conditions that may exist as perceived by

others.

Task Style: A management style that centers on the attainment of goals that center around results, not the needs of the people in the school environemnt.

Relationship Style: A management style that is extensively concerned with the relationships that exist in the school environment including mutual trust, respect for ideas, and consideration of teachers' feelings.

Iask-relationship Style:

A balance between the styles (Task and Relationship) that considers goal attainment important, but considers the needs of the subordinates in the school environment simultaneously.

\section{Summary}

This was a descriptive study which examined the status of teachers on a number of factors that are measured by the 
PTO. Among these factors were Satisfaction with Teaching, Rapport with the Principal, Rapport with Other Teachers, Load, Self-perceived Status, and a total score for Teacher Morale. These subscales and the Teacher Morale score were related to various biographical data including the experiential background, training, certification level, age and career stage of teachers. In addition, there was an integration of information drawn from a questionnaire administered in the form of an interview to the principals of each building. This interview included information on the levels of implementation on Riegle's (1971) eighteen middle school characteristics and the self-perceived managerial style of the principal.

The underlying assumption of this study, as immerging experts have indicated, was that, if there were training at the undergraduate level and state required certification for middle school teachers, they would be better prepared and aware of the job requirements that exist at this level. The prior awareness of such conditions might lead to greater initial levels of job satisfaction for middle school teachers, increased feelings of status for middle school teachers, and more effective processes for students at the middle school level. 
CHAPTER I I

\section{REVIEW OF THE LITERATURE}

\section{Job Satisfaction}

Upon reviewing the literature in this area, the first concern was to search more thoroughly for the definition of the term job satisfaction. This term has been studied since the thirties and the developments that followed the now famous Western Electric Studies. These studies, published in 1939 and commonly referred to as the Hawthorne Studies for the name of the plant where the studies were conducted, indicated that the production of the individuals in the plant increased not as a result of changes in the physical environment in which they worked but because of the increased attention that was being given to them as experimental subjects (Roethlisberger \& Dickson, 1939).

The Hawthorne experiment, under the direction of Elton Mayo, concluded, in this and subsequent studies, that the human factor has had a distinct impact on the levels of productivity that the workers were able to attain and maintain. In later writings, satisfaction has been viewed as highly subjective and associated with intrinsic rewards and the interaction between what the individual wants from the 
job and meastirement of how well the job meets desires (Greenfield \& Blase, 1981; Locke, 1969).

The intrinsic rewards of a job might include task variety, task uncertainty, social interaction that occurs on the job, the significance of the task to the individual, task identity, responsibility for results, and knowledge of those results (Sergiovanni, 1980).

\section{Hierarchies of Needs}

It may be assumed that job satisfaction is related to meeting the needs of individuals as they move through a hierarchy such as that postulated in the classic work of Maslow (1943, 1954) and the reappraisal of that work done by Aldefer (1969) and Porter (1981). Maslow (1943, 1954) proposed five levels of need that motivated people and formed a hierarchy consisting of physiological needs at the base, progressively moving through security and safety needs, social affiliation needs, esteem, and on up to the need to become s elf-actualizated. Moreover, there has been some speculation that since satisfaction is associated with intrinsic rewards, individuals have to fulfill their lower order physiological and safety needs before they can progress to the higher need levels. If individuals are fearful for their own existence, the concern with what satisfactions the job is bringing will be non-existent outside of the provision for basic survival needs. Porter (1981), acting on the 
assumption that the professional does not face the threat to his/her basic needs, reformulated Maslow's need hierarchy in an attempt to better match the 1 ife of the professional.

The base of the hierarchy becomes security followed in order by affiliation, self-esteem, autonomy, and self-actualiza-

tion (Porter, 1961). These universal human needs were looked at again by Aldefer in his work.

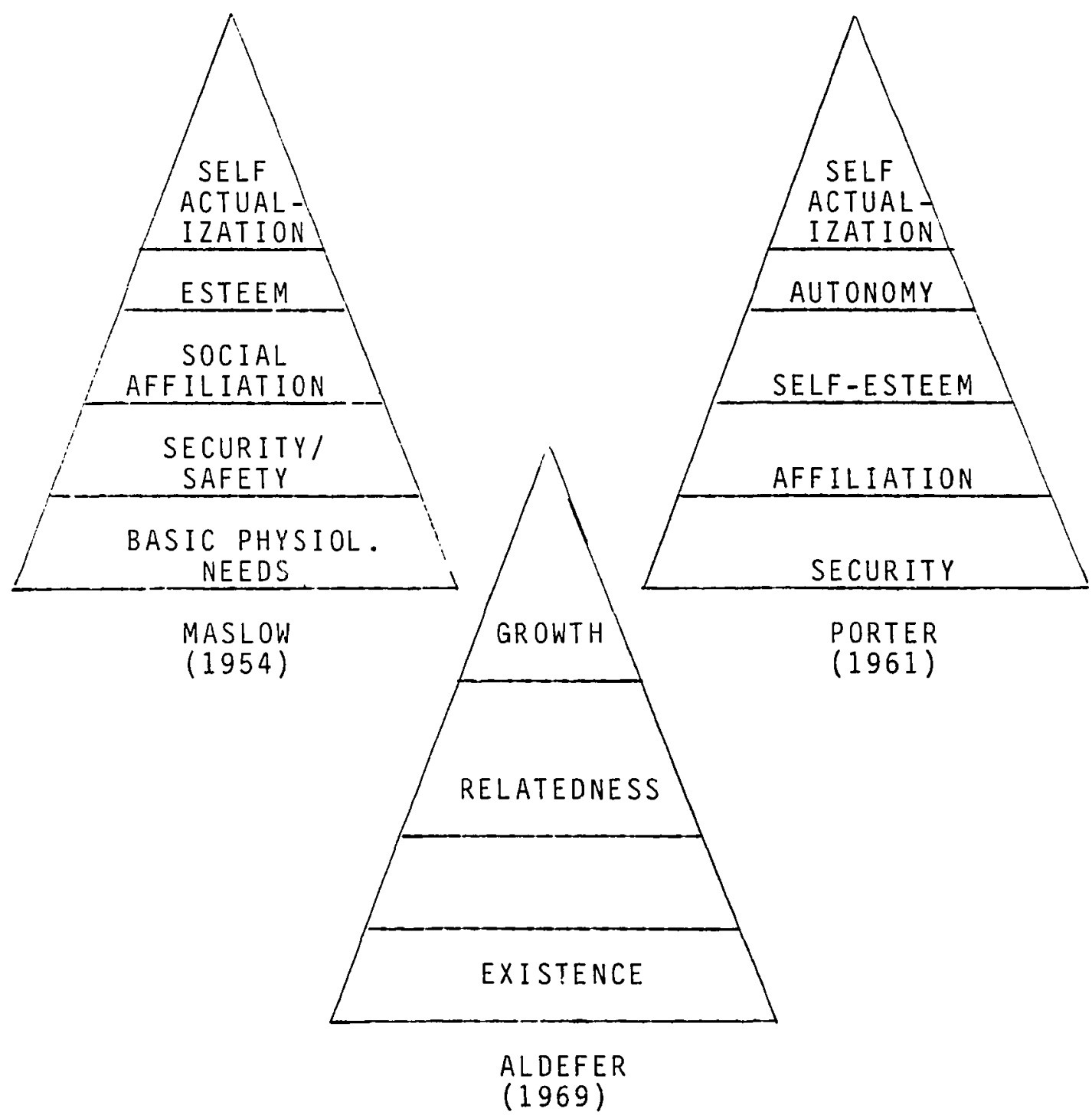

Figure 1. Hierarchies of needs. 
Aldefer (1969) redefined the five levels of Maslow's hierarchy into three levels: existence, relatedness, and growth. It could then be said that satisfaction would exist to greater or lesser degrees at all the levels of Aldefer's hierarchy. More broadly, job satisfaction, at a theoretical level, exists as a function of all the levels in the hierarchial schemes presented because each level is a function of the one that precedes it. For the purposes of this paper, Porter's (1981) terms will be used.

\section{From Need Fulfillment to Social Information Theory}

The most important impact of relating job satisfaction to the higher need levels within tre three hierarchies, is that it moves the focus on employee behavior out of the passive, submissive, dependent role which demands immature conformity (Argyris, 1964), into a more positive realm of behavior. Herzberg $(1959,1976)$ identifies two sets of $f a c-$ tors that affect the needs and behavior of individuals in organizations. In this bi-polar model, Herzberg labels one set of needs as Maintenance Factors (Hygiene Factors) such as organizational policy, supervision, salary, and security. These factors can lead only to dissatisfaction or the absence of dissatisfaction for an individual. The second set of needs referred to as Motivators, includes growth, recognition, advancement, and responsibility. It is these factors, according to Herzberg, which result in job 
satisfaction, or the absence thereof. The essence of this bi-polar model is that maintenance factors do not lead to job satisfaction, and the motivators do not result in dissatisfaction. The conclusion derived by Herzberg from this line of reasoning is that organizations need to simultaneously attend to both the maintenance and motivator factors, in order to eliminate the causes of dissatisfaction, while, at the same time, they promote opportunities for satisfaction.

Herzberg's work can be related to the writings of Maslow and others mentioned above if his maintenance factors are equated to the lower order needs set out in the three hierarchies. There is, however, a distinct difference in that Maslow, Aldefer, and Porter consider every level of the hierarchy as presenting a need that can become a potential motivator. In contrast, Herzberg considers the maintenance factors incapable of providing motivation.

From this it might be said that the fulfillment needs of the individual become the basis of satisfaction. The individual, in essence, must define these needs subjectively. Needs, as defined by the individual, may or may not be congruent with those of the organization. To address the concept of need-satisfaction a number of different models have been proposed by theorists. Historically, the assumption seems to have been that job satisfaction is linked with better performance on the job. There has been some 
questioning of this theory by Lawler and Porter (1968). Both men, however, support the concept that job satisfaction does lead to lower rates of turnover and absenteeism as well as the fact that there appears to be a low but consistent association of satisfaction with job performance (Lawler \& Porter, 1967). In reviewing Vroom's citations, Lawler and Porter found that 20 out of 23 studies that Vroom reviewed indicated a positive relationship between job satisfaction and performance. They point out that this is statistically possible no more than one time out of one hundred. In a study designed by Lawler and Porter to probe the relationship between the two areas, it was found that among professionals there is a statistically significant link between job satisfaction and performance. This link was much stronger among professionals than among blue-collar workers. Lawler and Porter conclude that ". . it becomes appropriate to be more concerned about which people and what kinds of needs are satisfied in the organization, rather than about how to maximize satisfaction generally" (Lawler \& Porter, 1967, p. 216).

Beyond this linkage found by Lawler and Porter many researchers and theorists have supported the concept of a linkage between job satisfaction and performance. Each of the need satisfaction models have made some basic assumptions: 
1. Persons have basic, stable relatively unchanging, and indentifiable attributes; e.g., needs and personality; and

2. Jobs have stable and identifiable characteristics that are relevant to those needs of individuals (Salancik \& Pfeffer, 1978).

Thus it is assumed that, if the job characteristics and the individual's characteristics are matched, the match will create more satisfied employees and higher levels of production. "Jobs that fulfill a person's need are satisfying; those that do not are not satisfying" (Salancik \& Pfeffer, 1977, . 4 428).

It appears, therefore, that the individual defines what he/she considers to be desirable. An individual may carry role expectations into a job, but this is not the whole story. The individual brings to the job a set of expectations for fulfillment and this may vary from individual to individual. Kuhlin (1963) found that the expectancies of needs fulfillment that were brought to the job by male teachers were far greater than the expectancies that were brought by female teachers. Kuhlin also uncovered information that indicated the level of job satisfaction of males was more closely related to need fulfillment than it was for women. It could be said that the extent to which a job fulfills the needs of the individual is the determinant of the level of job satisfaction. 
The work of Vroom (1964) is most closely associated with the need fulfillment theorists. Vroom's theory is often associated with the term expectancy model. The theory makes behavior the focus and assumes that it is rational behavior. In addition, it is assumed that the individual will anticipate the likely outcomes of the alternative ways of dealing with a problem, hence expectation of outcomes. If the expectation is met, the need is fulfilled. If the expectation is not met, it might either exceed the expectancy or fall short of that expectancy. In either case, the result is demotivating; the level of job satisfaction will fall; however, Vroom looked further at the model of expectancy fulfillment and addressed the problem that needs may have a relatively greater or lesser degree of importance to the individual. Thus Vroom adopted the valence-expectancy theory. In his application of the valence-expectancy theory Vroom (1964) addresses the concept that each need may have a differing level of importance, and failure to meet some needs of lower valence may be offset by success in fulfilling needs of greater value or valence. Therefore, rather than a simple subtractive model (job satisfaction = individual needs - job's ability to meet needs), it moves to a multiplicative model (job satisfaction = perceived amount of need fulfiliment $x$ the importance of the need to the individual) (Gruneberg, 1976). There still appears to be a link missing in this concept and Locke (1969) alludes to this 
when he notes that there is no consideration of how much the individual wants something and how much of something one wants (Locke, 1969).

Locke directly argues that the failures of job satisfaction theory to meet all the necessary challenges to the theories is the failure of the researchers to address the causality of the linkage (Locke, 1969). Job satisfaction cannot be measured without having some basic understanding of the process of emotions that are the root of the question. Remember that Locke defines job satisfaction as ". . the pleasurable emotional state resulting from appraisal of one's job as achieving or facilitating the achievement of one's job values" (Locke, 1969, p. 316). Therefore, Locke assumes that it is impossible to proceed with any study of job satisfaction until there is a common understanding of what emotions are and the difference between needing something and valuing something. Locke (1969) perceives that the individual may need something without any consciousness of its value; it will, nonetheless, have value; but one may value something while not needing it at a11. To value something is simply to wish it or desire it, not need it. One establishes or learns a value system but does not have to learn a system of needs. Needs simply exist and are there; they are not learned. It is more proper to consider job satisfaction the product of a value system and not a system of need fulfillment. An individual 
will first be cognizan: of something in the environment then will evaluate that item and place it in a value system which is learned. It is this process that will lead to the regulation of action for the individual or the level of job satisfaction that exists at that time (Locke, 1969).

Job satisfaction is the end product of a process that calls for the individual to enter the environment of the job with a set of values that are learned. The individual judges the job and the intrinsics about that job based upon a values system that has been learned and comes with that individual to the job. If the outcome is to be valued, it is judged or evaluated relative to the person's desires. The extent to which it fulfilis the desire is the regulation of the level of job satisfaction.

Lawler and Porter (1967) have extended the expectancy theories into a more complex format. The basis of their theory is that ". . . rather than being a cause of performance, satisfaction is caused by it" (p. 216). This could account, according to Lawler and Porter, for the low level of relationship between productivity and job satisfaction. In other words, the individual brings a set of values to the job that make it important to be productive. If there is a high output while on the job, the result is satisfaction. Lawler and Porter (1967) found that professionals tend to have a higher degree of relationship between job satisfaction and performance than do blue-collar workers. 
Rewards are important to the maintenance of high levels of job satisfaction, but the rewards must be perceived by the individual to be appropriate and equitable in terms of the effort that is expended for the production (Gruneberg, 1979; Lawler \& Porter, 1969;). Intrinsic rewards are, then, often more appropriate and are more directly related to the levels of satisfaction than are the extrinsic rewards such as pay and benefits. The most direct relationship is, however, between the perceived equitability of the reward, whether the reward be extrinsic or intrinsic in nature, and the performance.

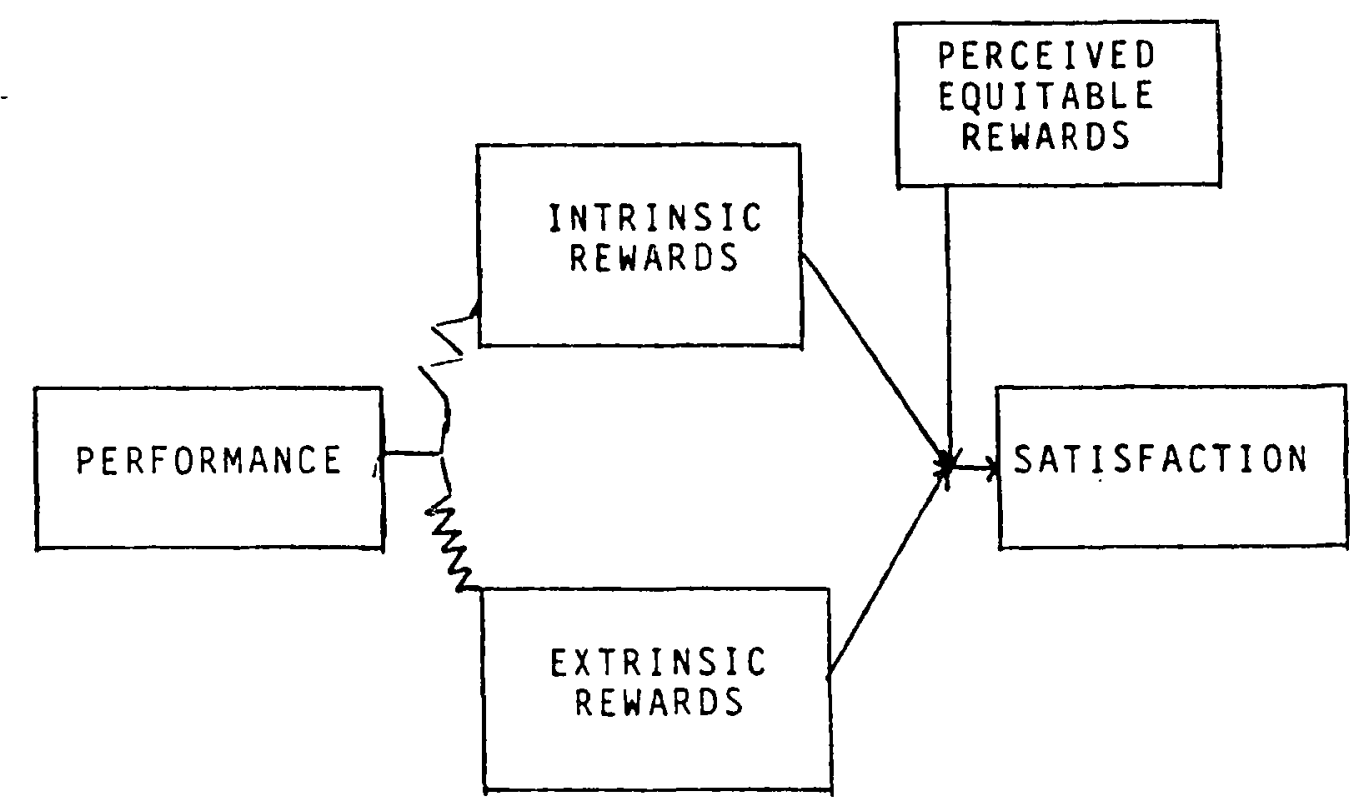

Figure 2. The relationship of extrinsic and intrinsic rewards to job satisfaction and perceived equitability; source: Lawler \& Porter (1969). 
Salancik has contributed support to the theory that the individual is perceiving the importance of the reward and its equitability. Salancik offers the social information perspective in his work with Pfeffer (1978). "The social information perspective holds that workers possess the ability to construct their own satisfaction by selectively perceiving and interpreting their social environment and their own past actions" (Salancik \& Pfeffer, 1978, p. 249). The extension made by Salancik and Pfeffer is also evident in this statement. They believe that there is a level of social interaction that affects the satisfaction levels of the individual. These theorists go so far as to indicate that the social pressures brought to bear on individuals may influence their individual predispositions. Salancik and Pfeffer postulate that ". . multiple social influences on attitudes are more consequential for predicting attitudes at work than are individual needs or other characteristics" (Salancik \& Pfeffer, 1978, p. 248). There is then the postulation that the job itself has little or no connection with the levels of job satisfaction except to the extent that the individual's desires and the characteristics of the job are matched to one another. It is at this juncture, then, that the characteristics of the job itself begin to have some significance if job satisfaction is to be understood. 
Nature of the Job and Job Satisfaction

Herzberg and Lawler have spent considerable time evolving theories of job design. In addition, Aldefer (1969) has looked at the area of job enlargement. Although there has been considerable questioning of the basic theories of Herzberg on Motivators and Hygienic Factors (Smith, Kendall, \& Hulin, 1969) on the basis that the research of Herzberg is impossible to replicate, Herzberg has produced some interesting postulates on the changes that should be made in jobs in order to increase the levels of satisfaction and possibly production. Job enlargement by itself is too broad

a concept to deal with because it can lead to what Herzberg calls job loading. This means that the number of duties are increased but there is no vertical growth of the job or job enrichment (Herzberg, 1966). Job enlargement does have some generalized attitudes associated with it that bear mentioning. First, overall job satisfaction tends to be higher. Herzberg would disagree and find that the levels of satisfaction are increased with the increase in the enrichment of the job, not the loading of the job. Meaningfulness of the job tends to increase in jobs that are enlarged. Again, Herzberg would indicate that this is associated with the enrichment of the job not the loading of it. Finally, enlargement is said to have ambiguous effects on interpersonal relations on the job. So, what then is the importance of 
job design on the levels of satisfaction that may affect job performance?

It is necessary for jobs to arouse higher order needs or desires and create conditions such that the people who perform the jobs will come to expect that better performance will lead to intrinsic rewards. Intrinsic rewards are those that are pursued by Herzberg when he speaks of job enrichment. Lawler (1969) indicates that there are three characteristics of jobs that arouse higher order needs:

1. The individual must receive meaningful feedback about his performance;

2. The job must be perceived by the individual as requiring him to use abilities that he values in order for him to perform the job effectively; and

3. The individual must feel he has a high degree of self-control over setting $h$ is own goals and over defining the paths to these goals.

In short, the job must contain characteristics that the individual perceives as providing meaning and challenge to the job. This is the process of enriching and is highly dependent on the perception of the employee, although Herzberg recommends that the employee $\mathrm{him} / \mathrm{herself}$ not be involved in the actual design of the job (Herzberg, 1966). Such changes in jobs may actually lead to the necessity to change the style of leadership and supervision that is practiced. 


\section{Job Satisfaction and Supervision}

Foa (1957) looked at the types of supervision styles and the effects of these styles on the workers. Foa determined that there were some basic premises that could be stated about the types of relationships that made for good working situations and those which would not be workable. Primary to the analysis was the consideration of the expectation of the employee as to what the attitude of the supervisor should be. This comes back again to the desires of the employee determining the level of satisfaction. If the satisfaction of the employee is to be increased it will be necessary to match the expectations of the employee with those of the supervisor particularly where the supervisor is authoritarian. It is destructive to place an authoritarian leader in charge of employees whose expectations are permissive. It is, however, acceptable and has little effect on satisfaction to place a permissive supervisor over an authoritarian employee (Foa, 1957).

\section{Other Related Factors and Job Satisfaction}

In general, research has shown that there are some other factors that are related to the levels of job satisfaction in employees. Most of these factors have to do with the individual differences between employees. 
First is the question of job satisfaction and the age of the employee. The results of research in this area leave much to be desired when it comes to females. Some studies (Hunt \& Saur, 1975) indicate that the same relationship exists between the age level and the satisfaction levels of females as that of males; i.e. a U-shaped curve with job satisfaction beginning high, declining and then rising again as age increases. It will be shown later that this is not true of the satisfaction levels in teachers, but that it is generally true of studies of male working populations. Saleh, Shoukry, and otis (1964) found that managerial employees indicated that their level of job satisfaction increases from the start of their employment, continues to increase until their 59 th year and then declines during the ages 60 to 65 .

Herzberg has postulated that the increasing level of satisfaction up to retirement is a product of the individual's increasing knowledge of the job, adjustment to the job and to his/her life situation in general (Herzberg, 1966). The midcareer decline that has been described by many studies may be associated with the failure to meet expectations. The subsequent increase in satisfaction levels is due to the readjustment of the individual to his/her lot in life. The relationship between the type of job and job satisfaction is affected by individual characteristics. 
England and Stein (1961) indicate that this difference between reference groups may be so significant that it calls for the development of instruments that measure levels of satisfaction only in specific employment groups.

This need for specificity is further borne out by the findings, again contradictory, on the levels of satisfaction as related to the levels of tenure of the employee. In studying blue-collar workers Gibson and Klein (1970) found a decrease in satisfaction with an increased tenure. Smith and Hulin (1969) reported an increase in satisfaction with increased tenure.

In addition to individual desires contributing to the levels of satisfaction, it is important to remember that reference group may have an influence on those levels. One such important reference group may be the gender of the individual. There is a high level of inconsistency in the findings relating to gender and the levels of job satisfaction. In their 1964 study of "Sex Differences in Job Satisfaction," Hulin and Smith found that female workers were less satisfied than male workers in three out of four group studies. This does not hold for all studies. Lortie (1975) found that women tended to be satisfied with teaching because they had somewhat lower job aspirations than males and found their satisfaction outside of the job.

It may, therefore, be assumed that the failure to find in the literature a singuiar response on the relationship of 
gender and job satisfaction may be associated with a number of factors. Part of the problem may be closely related to the postulations of England and klein (1961) that reference group may make a distinct difference. Females until recent years have been relegated to different levels of jobs than males; therefore, the female perspective on satisfaction and job level, promotion, prospects, pay, and other factors may differ greatly enough to influence their perspective on what is required to create satisfaction (Gruneberg, 1976). This result is again a strong affirmation of the concept that individuals bring to jobs a perspective that determines the level of satisfaction that will be perceived.

One final factor that is of importance is the relationship of the level of education of individuals and their job satisfaction. Again, there are somewhat mixed results from the studies of the association between the level of education of the individual and the level of job satisfaction that exists; however, it is possible to say that the results of Klein and Maher (1966) on the relation of pay satisfaction to educational level indicate that the college educated individuals tend to have lower levels of satisfaction than the high school educated individuals at the same pay level. This study was borne out in the results of a study by volimer and Kinney (1955) who found that college educated individuals were less satisfied than high school educated, and they, in turn, were less satisfied than 
elementary educated individuals. It is important to note, however, that Herzberg's investigations did not indicate that this is consistentiy true. Some of Herzberg's work indicates that there is a positive relationship between the level of education and the level of satisfaction (Gruneberg, 1979).

\section{Morale and Job Satisfaction}

For this study it is necessary to look not only at job satisfaction but the question of the relationship of job satisfaction and morale. Morale, like job satisfaction, probably consists of components that contribute to its total measurement. First, morale is related to "perceived productivity and progress toward the achievement of tasks that are significant to the organization (task achievement);" and, secondly, morale is the "perceived job satisfaction of individual needs through the interaction of the participant in his role within the work group and the total organization (needs-satisfaction)" (Guba \& Lonsdale as quoted in Bentley \& Rempel, 1980, p. 1).

Brayfield and Crockett (1955) went further in relating morale and job satisfaction. Using the terms interchangeably they indicate that "morale is not an abstraction; rather it is concrete in the sense that it directly affects the quality and quantity of an individual's output" ( $p$. 415). Further there is a relationship between the morale of 
the employee and the quality of the production of that same employee, because "employee morale - reduces turnover - cuts down absenteeism and tardiness; lifts production" (Brayfield \& Crockett, 1955, p. 398).

It would appear, then, that there is a close affinity between what is defined as job satisfaction and what is called morale. The PTO is a measurement of morale which is defined by Bentley and Rumpel as:

satisfaction as stemming from the total job situa-
tion. High morale is evident when there is interest
in and enthusiasm for the job. What is important in
morale is what the person believes and feels, rather
than the conditions that may exist as perceived by
others. (p. 1)

Specifically, given a certain job task:

- morale pertains to the factors in the individual's life that bring about a hopeful and energetic participation on his part so that his efforts enhance the effectiveness of the group in accomplishing the task at hand. (Bentley \& Rempel, 1980, p. 2)

The definitions and the literature seem to treat morale and job satisfaction as somewhat synonymous terms. In spite of this apparent similarity, morale will be maintained as a separate element from job satisfaction in reporting the study results.

\section{Job Satisfaction and Teaching}

Specific factors have been found to relate to the perception of job satisfaction are: structural variables of 
the job (Cummings \& Berger, 1976), supervisory style (Foa, 1957; Stogdil1, 1981), work group size and co-worker relationships (Porter \& Lawler, 1968), demographic factors (Gibson \& Klein, 1970; Herman, Dunham, \& Hulin, 1975; Herzberg, 1966; Hulin \& Smith, 1964; Klein \& Maher, 1966; Lortie, 1975; Vollmer \& Kinney, 1955;), and individual personality needs (O'Reily \& Braunstein, 1976). Some of these factors would suggest that the individual's goals and desires contribute to the perception of job satisfaction while others would suggest that the structure of the job itself affects the level of satisfaction.

In particular for this study, it is important to look at the structure and characteristics of the teaching job at the intermediate level and the types of individuals who choose to stay in the environment. In descending order, the characteristics of sociability, artistry, and enterprising nature have been attributed to successful teachers (Holland, 1973). It could, therefore, be presumed that teachers should be good at explaining things to others, supervising others, organizing, and getting people to do things (Hol1and, 1973). In addition, teachers tend to assign greater importance to intrinsic rewards than extrinsic (Chapman \& Hutcheson, 1982). Chapman and Hutcheson (1982) found significant differences in the self-rated skills and abilities of teachers and the criteria they used to judge the success, when comparing teachers who chose to stay in the profession 
with those who chose to leave. There was no correlation between the choice to leave and the sex, race, current age, or institutional training of the individual teachers. In the self-rating system, the teachers who chose to stay in the profession tended to have greater organizational skills and placed greater value on the recognition and approval of their superiors, family and friends. The teachers who chose to leave the profession assessed themselves as possessing greater analytical skills and placed more value on salary increases, job challenge and autonomy (Chapman \& Hutcheson, 1982).

Teacher satisfaction was found to be related to their perceived achievement in learning new things, leadership activities, and the recognition and approval received from supervisors and administrators, family and friends (Chapman \& Hutcheson, 1982). In a supporting study, it was found that, when assessing the needs of teachers, teachers have a perponderance of higher order needs (Erlandson \& Pastor, 1981). This may indicate that the job structure of teaching should be established around the meeting of higher order needs such as freedom to take responsibility for one's own goals and see these to completion. In the same study, it was found that there was a desire for close collegial relationships that seemed to be lacking (Erlandson \& Pastor, 1981). It is interesting that this would match the findings of Chapman and Hutcheson (1982) that indicated those 
teachers leaving education tended to place more importance on recognition of peers. It is possible that situations which provide for team teaching, team organization, or with potential for regular, varied teacher interaction may assist teachers in achieving fulfillment of this need.

Erlandson and Pastor (1981) suggest that it might be well to aspire to employ teachers who do not possess higher order needs. They reach this conclusion through reasoning that includes the fact that most of the results of their study indicate that the unfulfilled desires of teachers are those of a higher order. This would, in turn, lead to dissatisfaction if the teachers who were hired had higher order needs that would go unsatisfied. Therefore, the teacher who would be most satisfied is the teacher that assigns little importance to activities and accomplishments that, given the structure of the school, may be difficult to achieve. It is interesting to note that while the teachers should not hold these needs as part of their satisfaction set, they will be more highly satisfied if there are actual accomplishments in these areas (Chapman \& Lowther, 1982). In addition, the highly satisfied teacher is one who needs and subsequently receives, recognition from his/her supervisor or administrator, as well as family and friends.

Several of the researchers indicate that women tend to be more satisfied with the teaching profession than men (Chapman, 1982; Charters, 1970; Lortie, 1975). Tnis may be 
a cultural manifestation but there is no research to indicate the exact reason for its occurrence. Women's satisfaction may be related to ". . . the time teaching allows for home and family which, in turn, may help to offset specific working conditions in school" (Charters, 1970, p. 18).

In a study conducted on secondary teachers in Iowa in 1981 , Sweeney found that the greatest change in teacherperceived needs over the ten year period between 1970 and 1980 was in the area of security and was closely followed by shifts in teachers' feelings of self-esteem and selfactualization. If teachers are functioning at the level of maintaining and feeling security, Herzberg would indicate that there is no way to achieve satisfaction for these individuals since they are working mainly in the area of maintenance factors. If, however, they are feeling deficiencies in the area of self-esteem and self-actualization, these are areas that, in a need-satisfaction model, could be addressed by the organizational structures as well as the attitude of the teachers.

An interesting corollary to this study is the finding that there is a strong relationship between age and level of satisfaction of teachers. Teachers in the age category of 25-34 indicated the greatest need deficiency in the areas of esteem and self-actualization (Sweeney, 1981). 


\section{Career Stages}

The question then becomes whether the literature indicates any relationship between job satisfaction and the age of the respondent. There has been considerable work accomplished on career stages and the impact of age on satisfaction levels. Career stages are defined on age groupings that may vary from study to study but, generally, one could accept the classifications that are presented by Gould (1979):

1. Trial Stage (ages 22-30)

2. Stabilization Stage (ages 31-44)

3. Maintenance Stage (ages 45-65)

Vroom (1964) postulated that performance is a function of an individual's effort to achieve desired outcomes while satisfaction is a function of how we 11 those outcomes are realized. There appears to be at least a moderate relationship between the age of individuals and the level of satisfaction they will experience. The results of studies in the area of age and satisfaction levels appear to conflict with one another. In the case of public employees (employees of a public agency in the state of New York) there is a strong positive relationship between the more complex job with greater demands on the individual and the Trial Stage of the individual's career (Gould, 1979). In turn, there was a positive relationship between the complexity of the job and 
the level of satisfaction of the employees. As the employees moved into the Maintenance Stage there was a negative relationship occurring (Gould, 1979). On the other hand a study of secondary teachers, done in communities suburban to New York City, indicated that there was a negative relationship between the Trial Stage; i.e., the first three years of teaching and the level of job satisfaction. In particular, teachers in the first three years found that they were deficient in the skills that ultimately lead to satisfaction in what might be termed the stabilization Stage:

1. Learning the subject matter;

2. Developing classroom management and student control skills; and

3. Negotiating a proper social relationship with students (Greenfield \& Blase, 1981).

These inadequacies lead to feelings of fear, apprehension, and self-doubt. As the teachers moved into the years that Gould calls the Stabilization Stage, the major concerns shift from learning skills to eliminate dissatisfaction (Herzberg's maintenance or hygiene factors) to providing moral guidance for students, helping students solve their personal problems and a more holistic view of achieving outcomes with students academically, morally, and personally (Greenfield \& Blase, 1981). 
It is important to keep in mind the basic theories that call for the filling of the lower order needs (physiological, security) prior to the reaching of satisfaction of higher order needs. Herzberg would point to the maintenance or hygiene factors as those of work environment, type of supervisor, salary and fringe benefits, job security, attitudes and policies of administration, and status. It is the lack of these that can create dissatisfaction because of their absence. So when teachers were asked about those factors which created the greatest amount of dissatisfaction they related:

1. Paperwork and preparation;

2. Student absences;

3. Interference from other teachers, parents, supervisors;

4. Emotional fatigue; stagnation and boredom; and 5. Loss of enthusiasm for work (Greenfield \& Blase, $1981)$.

Using these general titles it is possible to bring these findings into congruence with the theory that Herzberg postulated. These would also fit into the theories of Maslow as interpreted by Porter since Maslow believed that needs existed at every level and could, therefore, be satisfied at every level.

There is a major threat to the teaching profession that manifests itself in the material on career stages. If 
there is a high job challenge perceived early in the career there is a greater chance that there will be higher job satisfaction (Gould, 1979), and resultant lower turnover and greater involvement. The exception to this is if the job complexity reaches a point that threatens the person's feeling of self-esteem. If there is a threat to self-esteem, there is no longer satisfaction and the discord may lead to the abandonment of the job (Gould, 1979).

Teachers who are feeling failure during the first few years as reported in Greenfield and Blase (1981) may be subject to these threats to self-esteem. It is this threat that may lead to the loss of potentially good teachers to an illusion of failure that will disappear when the teacher attains specific skills that have yet to be mastered.

\section{Job Satisfaction and Training for Middle School Teachers}

What do the results of the previously reported studies foretell for the measurement of job satisfaction as related to the middle level teacher? The state of oregon provides specialized training for teachers who are preparing to teach at either the elementary level or the secondary level. This means that if one is a graduate of a liberal arts institution in the State of Oregon, one will have taken methods classes and completed student teaching in what is defined as either the elementary or secondary level. Traditionally, this means that the methods courses are either aimed at the 
kindergarten though grades five or six, or grades nine through twelve in a specialized area such as social science, mathematics, or the pure sciences. The middle grades, especially the seventh and eighth grades, ended up with what is left over from both ends of the field.

The specific certifications in the state of oregon are K-9 and 5-12 meaning that the teachers who are chosen for grades 5-9 actually can be certified either way; elementary or secondary. This overlap accommodates all the possible combinations of grades for the middle school level. This historical choice of organization had been split between two options: elementary or secondary schools $K$ (1)-8 and 9-12, and the elementary $K$ (1)-6, junior high 7-9, and the secondary 10-12. With this division, the junior high was, theoretically, a transition school between the elementary of self-contained classrooms and the secondary school with subject matter orientation. In the course of years since the turn of the twentieth century, when the junior high school was first introduced, to the 1960's and the 1970's, the junior high school had turned into just that: mini high school. The curriculum covered the same sorts of areas down to classes that had the same titles. The activities were those of a high school including rally squads and interscholastic sports (Pook, 1981). The 1960's saw the inception of a new idea that rang similar to the initial thoughts about junior high schools at the turn of the century: the 
middle school concept. The junior high purpose ". . was to provide an educational organization specifically designed for early adolescents" (Pook, 1981, p. 102). The middle school was, again, an ". . attempt to provide the early adolescent with a unique educational program" (Pook, 1981, p. 102). For the last twenty five years the literature has reflected the lack of training of teachers for these students in the middle and these schools in the middle (George \& McEwin, 1978). What we had were not only students and schools in the middle, but teachers in the middle as well. Guidelines for this training have been laid out including:

1. A special knowledge of the needs and characteristics of tranescent (middle) level students;

2. Training in the types of goals and programs fitted to these students;

3. A broad academic background that includes specialization in at least two allied areas of the curriculum;

4. Special methods of teaching emerging adolescent children;

5. Courses in the teaching of reading;

6. Training in affective education and techniques of guidance;

7. Learning theory;

8. Skills in classroom group management; 
9. Continuing seminars which help the prospective teacher integrate what has been learned; and

10. An early and sustained series of clinical experiences in middle school beginning with observation and progressing to the level of full responsibility for the learning process (George and McEwin, $1978)$.

The concern then becomes one of implementation, but regardless of the enthusiasm of the middle level educator for his/her training for the middle level, if the states fail to require the existence of such a program (DeMedio, 1980) there will be little necessity for such a program (McEwin, 1983). In a study published in the Fall, 1982, McEwin and Alexander studied the status of such university programs. Of the 538 institutions that responded to the questionnaire that was distributed nationwide to all members of the American Association of Colleges of Teacher Education, only 162 of the institutions provided programs that directly addressed teacher preparation for the middle school level. Only 147 of these programs were provided at the undergraduate level. Eighteen of the programs were at the doctoral level only.

When analyzing the program requirements that are recommended for this training, it was found that only 72 of the institutions offered field experience at the undergraduate level. Other findings are shown in Table I. 
TABLE I

PERCENT OF INSTITUTIONS OFFERING

SELECTED COURSES/EXPERIENCES

(MCEWIN AND GEORGE, 1982)

\begin{tabular}{lcc}
\hline COURSES/EXPERIENCE & UNDERGRADUATE & GRADUATE \\
\hline Field Experience & 72 & 17 \\
Middle Level Curriculum & 63 & 44 \\
and Instruction & 63 & 33 \\
Reading & 49 & 34 \\
Middle School Concept & 49 & 33 \\
Middle Level Learner & 37 & 17 \\
Academic Concentrations: & 33 & 13 \\
One & 5 & 0 \\
Two & 1 & 1 \\
Three & 9 & 9 \\
Four or More & & \\
\hline
\end{tabular}

of the states providing such training the greatest participation was by Alabama (13 programs), Georgia (14 programs), Indiana (14 programs), Missouri (10 programs), North Carolina (12 programs), and West Virginia (11 programs). The State of Oregon had seven reporting institutions, but none of them provided any specialized middle school training at any level (McEwin \& Alexander, 1982). Florida is an example of a state that is developing programs to meet the requirements created by the State of Florida. There are presently four programs in the State of Florida for middle school preparation. The University of Florida at Gainesville provides one of those programs in response to the certification process of the state (George \& McEwin, 1978; McEwin, 1983; McEwin \& Alexander, 1982). 
Returning to DeMedio's (1980) findings in Ohio, middle school teachers and principals responded that there was a need for special certification for the middle school level as outlined by George and McEwin (1978). This may be connected to the need for skills at the middle level of teaching that do not overlap with the skills at either the elementary or secondary levels. The failure of teachers and principals at other levels to see the need for specialized training in DeMedio's study would bear out such a conclusion. In addition to this, McEwin (1983) has postulated that there may be a lack of status associated with being a middle level educator. Since the states frequentiy fail to recognize the need for a special certification there is a loss of status by middle school teachers to those educators that are formally recognized by the state; the elementary and secondary educators (McEwin, 1983).

\section{Job Satisfaction and the Middle School}

What, then, is the tie to job satisfaction for the middle school teacher? Maslow, Porter, and Herzberg give some hints. Recall that there are lower order and higher order need fulfillments. If this is true, there is a loss of self-esteem that may be postulated for teachers at the middle school level who are not professionally recognized as having unique skills and training. If this lack of status is a factor, it could affect negatively the satisfaction 
levels of such teachers as this level. Since the study of Greenfield and $B I$ ase was done among secondary teachers who were trained as secondary teachers, it could be assumed that their preparation was more directly aimed at preparation for the job they would face than is the middle school teacher's preparation. Middle school teachers would receive no training aimed at the level at which they are teaching. Even with the more exacting training, the secondary teachers studied by Greenfield and Blase (1981) faced problems of adjusting to the organizational climate and the demands of the job. This adjustment problem leads to diminished satisfaction. The study did find that, at the end of the third year of experience, these conditions tended to mitigate themselvas, The study does not address itself to the idea of attrition of the teachers who failed to adjust, but points out that the teachers had learned to:

1. Schedule tests and writing assignments so as not to burden themselves;

2. Develop a sense of continuity among the lessons;

3. Use preparation time more efficiently;

4. Learn to develop long range plans; and

5. Have gained more personal freedom (Greenfield \& B1 ase, 1981).

What appears to have happened is that the teachers are learning the job. These are teachers who have been trained 
for the specific job they are functioning in on a day-to-day basis. Even with this training Lortie (1975) found that:

One of the features of teaching is the abruptness with which responsiblity is assumed. In fact, a young man or woman typically is a student in June and a fully responsible teacher in september. ( $p$. 73)

Unlike other professions where there is an apprenticeship, teaching provides only a short period of student teaching. This experience, usually lasting no more than one university term, ends and the new teacher is thrown into full responsibility for teaching.

Tasks are not added sequentially to allow for gradual increase in skill and knowledge; the beginner learns while performing the full-complement of teaching duties. The anxiety so induced is exacerbated by his probationary status.. . (Lortie, 1975, p. 72)

Middle level teachers are faced with lowered status and compounding lack of training. The training may be insufficient for the secondary level but it it totally inadequate for the middle level.

\section{Middle School Characteristics}

There is a repetition of the same basic characteristics for a middle school throughout much of the literature in this area. Most of the studies that have looked at levels of implementation of middle school characteristics have been based on the work of Georgiady, Reigle, and Romano (1973). Beckman (1981) used these same characteristics in a 
replicative study completed in Missouri. Those characteristics are part of a questionnaire produced by Georgiady, Reigle, and Romano and used by Beckman in his study. The characterisitics are:

1. Continuous progress non-graded organization that allows students to progress at their own individual rate regardless of chronological age;

2. Multi-material approach to instruction;

3. Flexible schedules;

4. Social experiences appropriate for tranescent youth;

5. Physical and intramural activities based solely on the needs of students;

6. Team teaching;

7. Planned gradualism to ease the transition from childhood dependence to adult independence;

8. Exploratory and enrichment studies;

9. Guidance services;

10. Independent study;

11. Basic skills repair and extension;

12. Creative experiences;

13. A security factor that meets students needs for a security group;

14. Evaluation that is personal, positive, nonthreatening, anci individualized;

15. Community relations program that is two-way; 
16. Broad spectrum of student services; and

17. Auxiliary staffing to provide individual help.

The origin of this list of characteristics is the 1971 study done by Reigle in which he surveyed 136 Michigan middle schools to determine the levels of implementation that existed at that time. Historically, many of the transitions to middle schools have been for purposes of population adjustment within district, desegregation adjustments, or on the grounds that the district is making the choice to appear to be innovative (Lounsbury, 1980). These phenomena have been observed by a number or researchers who have looked at the area of middle schools:

This current period of controversy - middle school versus junior high school - gives schoolmen an excellent opportunity to play the "numbers" game: fitting organization to facilities while pretending to make such decisions on psychological, sociological and educational principles. (Brimm, 1969, p. 5)

In truth, the only difference between most junior highs and middle schools is in name and grade organization. Founded more upon grounds of administrative expedience than of educational improvement, most middle schools have simply moved the junior high structure, program, and schedule down a grade or two. Or, the programs of grades 5 and/or 6 from the prior elementary school and that of grades 7 and/or 8 from the junior high are maintained so that in reality, two very different schools are housed in the same building. Most research on the topic reports that middle schools tend to have the same high school-type of program of studies, departmental organization, Carnegie units, interscholastic athletics, and early socialization activities that have long characterized and plagued junior highs.

Based upon these findings, it should come as no surprise that several studies have found a significant gap between the main tenets of the theoretical 
middle school concept proposed by leading middle school authorities and actual educational practices

in most middle schools (Gatewood, 1973, p. 223).

In an effort to gain some better understanding and data on the levels of implementation, there have been a number of studies devised to discover whether middle schools are middle schools in name only or are to a greater degree implementing the programs that are listed by Reigle as distinguishing the middle school from the junior high (Beckman, 1981; Billings, 1973; Bloom, 1974; Bohlinger, 1981; Cummings, 1975; Danie1, 1973; Flynn, 1971; Frank1in, 1973; Kramer, 1974; Phelps, 1975; Pook, 1981; Raymer, 1974). of these studies the most current will suffice to demonstrate the levels of implementation that were found. Bolinger (1981) conducted a study of 166 middle schools in Ohio using the Reigle instrument. Of the 168 schools that responded to the survey (grade level organizations were 6-8 and 5-8) the composite implementation level of the scores was. $50.5 \%$. This ". . indicates that, in generai, the eighteen middle school characteristics have not been implemented to a great degree" (Bohlinger, 1981, p. 93). Only multi-material approach, physical experience appropriate to the level, and student services received scores that were in the $65 \%$ to $80 \%$ range. Continuous progress, flexible schedules, team teaching, and exploratory and enrichment activities received composite scores of $33 \%$ or less indicating extremely low implementation levels. 
Beckman (1981) studied the levels of implementation using the same eighteen characteristics. The sample that Beckman studied was drawn from Missouri schools and consisted of 101 respondent schools. Of the respondent schools 50 were middle schools which were compared to elementary and junior high schools to see if the levels of implementation of the characteristics desired in middle schools were statistically higher for the middle schools. Beckman found that the mean implementation of level of the middle schools was $54.4 \%$ while that of the elementary and junior high schools were $49.6 \%$ and $51.0 \%$ respectively. From this Beckman concluded that "a review of the Missouri middle schools studied revealed that the schools with the titles of elementary school, middle school, and junior high school were more similar than different in terms of implementation of the basic middle school principles" (Beckman, 1981, p. 75). Finally, in a striking statement that reflects the concerns of many middle school researchers, Beckman states that "The Missouri middle schools have not implemented to a great degree the basic middle school principles and thus exist more in theory than in reality" (Beckman, 1981, p. 76).

Finally, Pook (1981) looked at the levels of implementation and the effects that this level has on the job satisfaction of teachers in the schools. Pook modified the instrument (the Middle School Practices Index or MSPI) to fit her study and to eliminate certain problems. The instrument 
did, however, still address the eighteen characteristics of the middle school. Using the modified instrument in combination with the PTO, Pook tried to correlate the levels of implementatation with the levels of satisfaction that existed in the middle schools in the state of Colorado. The questionnaires were mailed to a total of 340 middle school teachers and the final sample consisted of 252 respondents. Pook grouped the responses into those which represented schools with high, low, and medium levels of implementation. She found that overall job satisfaction of middle school faculty does not vary significantly in low, medium, or high implementation schools (Pook, 1981). However, Pook did find that the level of satisfaction with the curriculum did increase as the level of implementation increased. In addition, high levels of implementation did correlate with higher levels of satisfaction with the levels of community support and school facilities. There was greater dissatisfaction with the teaching load in the more highly implemented schools.

It would appear then that there is a reason to bring together the concepts of job satisfaction, morale, rapport, and middle school principles. The cited studies indicate there may be a relationship between these elements that may be connected to characteristics of middle school teachers. Middle school teachers may possess measurably different characteristics which will lead to greater understanding of this segment of the teaching profession. 
CHAPTER II I

GENERAL METHODOLOGICAL DESIGN

\section{Introduction}

Three sets of data were gathered from middle school personnel from four separate districts that are suburban to a large metropolitan area in the Northwestern United States. The personnel involved were from middle schools in these four districts and included the principal of each school and the teachers of the school. In order to look at the levels of morale and job satisfaction (among the other factors), the Purdue Teacher Opinionaire (PTO) was given to the teachers of the middle schools in the sample. Simultaneously, an instrument to report biographical data on each of the teachers was included. Finally, an Administrators' Questionnaire was given to each of the principals in interviews that lasted from an hour and a half to two hours each. The data gathered from the application of the PTO were analyzed to determine the levels of morale, job statisfaction, and other factors that were present among the middle school teachers in the sample. These levels were then analyzed in relation to the independent variables of biographical nature that were obtained from the biographical 
instrument. Specifically, these data included the gender, teaching level, years of experience, years in present position, and certification levels of the individual teachers. The Administrators' Questionnaire provided information about the levels of implementation on Riegle's eighteen principles of middle schools as well as communication levels in the schools. In addition, the principals were asked to describe their own philosophies of middle schools and management practices. These qualitative items were gathered to add to the description of the status of the schools that were studied.

\section{Design of the Investigation}

This study was designed as a descriptive study to look at the levels of morale and various factors among middle school teachers in buildings that were described by their districts as middle schools. The sample was limited to districts that were suburban to a large metropolitan area and that had no more than three but no less than two schools that were titled "middle schools." The districts had other common characteristics. The student populations were predominantly white, the socio-economic level ranged from lower middle to upper middle class, and the school populations were under 650 students. This meant that teacher populations did not surpass forty in any school so that 
communications were still feasible among members of the teaching staffs.

The time frame of the study was restricted as much as possible so that the sampling was done at approximately the same period of the school year for all of the schools in the sample. The month of April was chosen since it fell outside of the holiday period but before the end of the year pressures that can increase levels of dissatisfaction and stress among teaching personnel. At the same time, this period of the year does not falsely provide a high satisfaction and morale level due to a lack of stress that might be created by a summer survey or an early fall survey. All of the schools were originally planned for sampling during a three week period at the beginning of April 1984, however, an unforeseen event delayed the participation of one of the schools until the final week of April 1984 (the fourth week). The principal of each building was interviewed on the same day as the teacher instruments were distributed in each of the buildings. All of these interviews were completed in one sitting with the exception of the delayed building. In that building the interview was completed in two sittings, one week apart, due to time constraints. (For a schedule, see Appendix A.)

For purposes of this study the independent and dependent variables were determined to be those identified in the following table: 
TABLE II

DEPENDENT AND INDEPENDENT VARIABLES

\begin{tabular}{|c|c|}
\hline INDEPENDENT VARIABLES & DEPENDENT VARIABLES \\
\hline $\begin{array}{l}\text { Biographical Data } \\
\text { Gender } \\
\text { Years in Present Position } \\
\text { Years of Teaching } \\
\text { Certification } \\
\text { Oregon Institution Graduate } \\
\text { Grade Levels Taught } \\
\text { Subject Areas Taught } \\
\text { Training for Middle School } \\
\text { Teaching } \\
\text { Principal's Instrument } \\
\text { Levels of Implementation of } \\
\text { Middle School Principles } \\
\text { Self-perceived management Style }\end{array}$ & $\begin{array}{l}\text { The PTO } \\
\text { Measurement of Morale } \\
\text { 1. Teacher Rapport } \\
\text { 2. With Principal } \\
\text { 2. Tatisfaction with } \\
\text { 3. Raching } \\
\text { 4. Teachers } \\
\text { 5. Teacher Salary } \\
\text { 6. Curriculum Issues } \\
\text { 7. Teacher Status } \\
\text { 8. Community Support } \\
\text { 9. Sor Education } \\
\text { 9. School Facilities } \\
\text { 10. Cond Services } \\
\text { Community Pres- } \\
\text { sures }\end{array}$ \\
\hline
\end{tabular}

Although the PTO provides an overabundance of information for this study, the stress is the independent factors of Teacher Rapport with the Principal, Satisfaction with Teaching, Rapport Among Teachers, and Teacher Status. Other factors are mentioned but are not major components of this descriptive study.

\section{Instrumentation}

The PTO provides a total score that is descriptive of the level of teacher morale. In addition to this total measurement, the instrument provides subscale scores in ten factors that break morale into components. Rempel and 
Bentley (1964) defend this multi-dimensional approach to the measurement of morale and used a factor-analysis approach (". . a principal components analysis of the image-covariance matrix followed by an oblique rotation of the extracted factors" [Rempel \& Bentiey, 1964, p. 3]) to determine the component questions for each of the factors.

The PTO, as mentioned, has ten subscale scores from the following factors (definition provided in Appendix A):

$\begin{array}{lr}\text { Teacher Rapport with Principal } & \text { Factor } 1 \\ \text { Satisfaction with Teaching } & \text { Factor } 2 \\ \text { Rapport Among Teachers } & \text { Factor } 3 \\ \text { Teacher Salary } & \text { Factor } 4 \\ \text { Teacher Load } & \text { Factor } 5 \\ \text { Curriculum Issues } & \text { Factor } 6 \\ \text { Teacher Status } & \text { Factor } 7 \\ \text { Community Support for Education } & \text { Factor } 8 \\ \text { School Facilities and Services } & \text { Factor } 9 \\ \text { Community Pressures } & \text { Factor } 10 \\ \text { The reliability of the instrument was determined by } & \\ 1 \text { and Bentley through a test-retest situation in which } \\ \text { ollowing correlational data were obtained for a sample } \\ \text { sting of } 3,023 \text { teachers in 16 oregon schools and } 60 \\ \text { na schools: }\end{array}$


TABLE III

COEFFICIENTS ALPHA FOR PTO

FACTOR

\begin{tabular}{ll}
\hline 1. Teacher Rapport with Administrator & .88 \\
2. Satisfaction with Teaching & .84 \\
3. Rapport Among Teachers & .80 \\
4. Teacher Salary & .81 \\
5. Teacher Load & .77 \\
6. Curriculum Issues & .76 \\
7. Teacher Status & .81 \\
8. Community Support for Education & .78 \\
9. School Facilities and Services & .80 \\
10. Community pressures & .62 \\
\hline
\end{tabular}

(Bentley \& Rempel, 1980, p. 5)

The following table provides the inter-factor correlations for the PTO - decimals omitted (Bentley \& Rempel, 1980, p. 6):

TABLE IV

INTER-FACTOR CORRELATIONS

OF THE PTO

\begin{tabular}{|c|c|c|c|c|c|c|c|c|c|c|}
\hline FACTOR & 1 & 2 & 3 & 4 & 5 & 6 & 7 & 8 & 9 & 10 \\
\hline $\begin{array}{r}1 \\
2 \\
3 \\
4 \\
5 \\
6 \\
7 \\
8 \\
9 \\
10\end{array}$ & -- & 35 & $\begin{array}{l}48 \\
39\end{array}$ & $\begin{array}{l}25 \\
18 \\
34\end{array}$ & $\begin{array}{l}32 \\
40 \\
33 \\
18\end{array}$ & $\begin{array}{l}37 \\
30 \\
44 \\
24 \\
38\end{array}$ & $\begin{array}{l}37 \\
54 \\
42 \\
38 \\
43 \\
40\end{array}$ & $\begin{array}{l}40 \\
42 \\
47 \\
36 \\
35 \\
44 \\
61\end{array}$ & $\begin{array}{c}32 \\
29 \\
37 \\
31 \\
39 \\
51 \\
40 \\
44\end{array}$ & $\begin{array}{l}31 \\
39 \\
36 \\
18 \\
55 \\
37 \\
47 \\
47 \\
55 \\
--\end{array}$ \\
\hline
\end{tabular}


In addition to the original work done by Bentley and Rempel (1963) on the PTO, follow-up work has been done to provide median distribution for elementary and junior/senior high faculties in this study. In the original normative testing, it was determined that there was not a significant difference between the scores of the elementary level and those of junior/senior high schools; however, subsequent research by the Purdue Measurement and Research Center in 1970-72 and 1972-74 determined that "elementary school faculties scored consistently higher on all PTO factors and on most PTO items than did junior high and senior high school faculties" (Bentley \& Rempel, 1980).

Based on these more recent results, new norms were established for junior and senior high faculties as well as elementary faculties. These norms are based on median scores for items with a response range of four. These norms are listed in Table V:

\section{TABLE V}

PERCENTILE DISTRIBUTION OF FACULTY SCORE MEDIANS BY FACTORS

\begin{tabular}{lcccccccccc}
\hline \% ILE & 1 & 2 & 3 & 4 & 5 & 6 & 7 & 8 & 9 & 10 \\
\hline 90 & 3.64 & 3.72 & 3.60 & 3.23 & 3.68 & 3.39 & 3.18 & 3.42 & 3.56 & 3.72 \\
75 & 3.36 & 3.64 & 3.35 & 2.91 & 3.58 & 3.13 & 2.97 & 3.08 & 3.19 & 3.59 \\
50 & 3.17 & 3.56 & 3.21 & 2.53 & 3.39 & 2.90 & 2.78 & 2.83 & 2.86 & 3.44 \\
25 & 2.86 & 3.43 & 3.09 & 2.12 & 3.18 & 2.64 & 2.62 & 2.52 & 2.44 & 3.24 \\
10 & 2.54 & 3.31 & 2.90 & 1.82 & 3.02 & 2.28 & 2.43 & 2.14 & 1.96 & 3.07 \\
\hline
\end{tabular}


Test-retest means from the norming sample are provided in Appendix A. These norms are based on 174 junior and senior high school faculties that submitted completed PTO forms to the Research Center (Bentley \& Rempel, 1980).

The validation of the PTO was a peer judgement procedure. A rating form was used which asked the responding teachers to rate a number of the teachers on their staff by the level of morale (high and low). The means of these groups were calculated, and these means were grouped in such a way that "high," "low," and "middle" levels of morale were established. The differences between the three groups of teachers were in the directions expected, and the level of significance was beyond the.05 level (Bentley \& Rempel, 1980). It must be noted, however, the specific validity data cited for the PTO is meager (Buros, 1972).

The questionnaire (see Appendix A) used to collect information on the levels of implementation of middle school principles and provide a self-perceived management style analysis for the principal of each school was designed around the eighteen principles of middle schools as designed and tested by Riegle (1971) in his doctoral dissertation. These same principles have been used in replicative studies (Beckman, 1981; Bi1lings, 1973; Broom, 1974; Cummings, 1975; Daniel, 1973; Flynn, 1971; Franklin, 1973; Georgiady, Riegle, and Romano, 1973; Pook, 1981).

Although Riegle's instrument was not used, the principles remained identical and only communication factors 
were added. These communication factors included communication by teachers with other teachers between grade levels, within grade levels, and across disciplines within the school. In addition, the questionnaire asked for information on the management style that the administrator used. It is not expected that these data will be considered to be statistically important to the study, rather it is hoped that the instrument will add qualitative data to provide a fuller picture of the climate of the schools in this study. To test the instrument, it was administered to three school administrators to determine if the instrument was easily understood and appropriate for an interview situation. In addition, time schedules were established so that appropriate appointments could be made with the principals of the schools involved in the study.

Finally, the biographical data instrument was patterned after one used in other doctoral studies in recent years at Portland State University including those of Waggoner (1983) and Wax (1983). Since both of these dissertations were based on data collected from school administrators, alterations had to be made to make it better fit the needs of a study with teachers. Once these alterations were made the instrument was administered, in conjunction with the PTO, to twelve junior high school teachers to determine the clarity of the instrument and the time involved in administrations of the two instruments. Several changes were 
made in the final form of the biographical data sheet that was used. (See Appendix A for copies of all instruments used.)

\section{Data Gathering Procedures}

The PTO and biographical instruments were distributed to the teachers personally by the researcher. In all cases the principal of the school was asked to make this a part of the regularly scheduled faculty meeting so that the teachers would not be required to attend a special meeting to obtain the instruments. At the time of the meeting, the researcher explained the purpose of the study to the faculties, responded to any questions the teachers had, and explained to the teachers how they could obtain copies of a summary of the findings.

Al1 questionnaires were completed no later than May 15, 1984, and were returned to the main office of each building where the secretaries maintained an envelope in which the questionnaires were collected. Two weeks after the surveys were handed out in each building, the researcher returned to the building and distributed a flyer in the boxes of all faculty members to remind them to complete the questionnaire and return it to their school office. Extra questionnaires were left at the school at that time in case any teacher had misplaced his/her questionnaire. The separate numbering of these replacement questionnaires allowed 
tracing of any such replacements. (Note: only two such replacements were employed by the teachers.)

The researcher returned to the schools on an agreed to ending date and picked up all of the completed instruments. Four of the respondents had made a choice to send the questionnaire directly to the researcher's home address which was provided on the cover letter that accompanied each questionnaire.

The questionnaire used with the principals of the middle schools who participated in the study was completed on the same day that the teacher questionnaires were distributed in all but school number eight's case. At school number eight the principal was under time constraints so the final half of the questionnaire was completed one week following the first half of the interview. In all cases, the questionnaire was presented in the form of an interview and the same format for the questions was followed. (See Appendix A.)

District office permission to work in the schools was obtained in all districts except one which, when contacted, said that it was entirely up to the administrator in each building to make that determination.

A11 respondents, and the school districts, were assured that confidentiality would be maintained. All teacher questionnaires were coded only for district, school building, and questionnaire order number. No names were listed 
with any of the questionnaires and no effort was made to identify respondents. Table VI provides a listing of the identification number to be used for each district and school.

TABLE VI

NUMBERING OF SCHOOLS AND DISTRICTS

\begin{tabular}{ccc}
\hline DISTRICT & IDENTIFICATION & OF SCHOOLS IN DISTRICT \\
\hline 1 & 7,8 & \\
2 & 1,4 & \\
3 & 2,9 & \\
4 & $3,5,6$ \\
\hline
\end{tabular}

\section{Statistical Methodology}

The means, medians, and standard deviations for the PTO and all of its subscales were computed and are displayed in tables in the body of Chapter IV or Appendix B. In addition, the means and standard deviations of several of the subscales selected upon biographical, independent variables were computed and reported. The item medians were also computed and are reported to provide a picture of the sample's relation to norming sample percentiles for secondary and junior high school teachers determined by Bentley and Rempel $(1980)$

The responses to the PTO subscales and total score and selected independent variables were analyzed using analysis of variance with alpha set at .05 . These were followed by univariate analysis of variance and Scheffé tests where 
appropriate. Among the independent variables so analyzed were gender, career stage by age, the number of years taught, and the certification level of the respondents. Responses on implementation of middle school characteristics from the Administrators' Questionnaire were statistically analyzed to yield means which are reported. Finally, a correlation matrix was computed for the PTO in order to investigate the relationship of the factors on the PTO to the assessment of morale for this sample.

\section{Classification of Management Styles}

Using the self-perceived statements of management style obtained in the administrator interviews, key words and phrases were used to place the principals into management styles. If the principals talked about resources, goals, time, and generally getting the job done but gave no attention to the people in the environment, the label Task was applied to the principal's style. On the other hand, if the principal spoke of the people (particularly the teachers) and of participatory style, the label Relationship was applied to the self-perceived style. Those principals who spoke about both elements were given the label Taskrelationship.

\section{Summary}

The sample in this study consisted of four disticts suburban to the city of Portland, Oregon. The teachers in 
the middle schools in these districts responded to two instruments; the PTO and a biographical instrument. The principals of each of the buildings were interviewed using a separate questionnaire designed to measure the levels of implementation of the eighteen characteristics of middle schools as put forth in the work of Riegle (1971). In addition, the principals were asked to describe their management styles.

The study was descriptive in nature in that no variables were manipulated. The independent variables were those features about the teachers as reported in the biographical instrument. The dependent variables were the scores on the PTO and its subscales.

Coefficient alphas and inter-factor correlations were provided for the PTO. In addition, medians for specific percentiles derived from the norming sample were provided.

The specific statistical methodology was discussed. This design included the computation of means, medians, and standard deviations for items, subscales, and the total score for the PTO. The scores from the PTO and independent variables were analyzed using analysis of variance, unvariate analysis of variance, and Scheffé tests where appropriate. Means were calculated for portions of the Administrators' Questionnaire as well. A correlational matrix was computed for the PTO subscale scores. 
CHAPTER IV

PRESENTATION OF THE FINDINGS

This chapter presents the results of the research investigating the status of and relationships which exist between middle school teachers and their scores on the scales of the Purdue Teacher Opinionaire (PTO). In addition, the chapter presents the findings from the related administrator interviews and anecdotal information.

\section{Sample}

The sample is described in terms of its size, the schools from which the sample was taken, the distribution of the respondents within those schools and within the districts, levels of training for middle school teaching, grade levels and subject areas taught, age, gender, certification, number of years taught and in present position, and whether or not the respondents are graduates of Oregon institutions of higher education.

\section{$\underline{\text { Size }}$}

Questionnaires were distributed to all 268 members of the teaching staffs of the nine schools in four school districts that were included in the study. These 268 teachers included sixth, seventh, and eighth grade teachers in the 
middle schools that were studied. The enrollment of the school provides further comparative data. All of the districts are classified as suburban districts with largely white populations. Each district had at least two, but no more than three middle schools and all middle schools in the district were included in the study sample. Of the 268 distributed questionnaires, 173 were returned for a return rate of $65 \%$. Table VII indicates the percentages of return for each of the schools in the sample as well as the enrollment, number of certified staff in each school, and grades enrolled in the school. Of the 173 questionnaires returned, 171 of those were usable responses. Two were eliminated because of incomplete data or failure to return a biographical sheet with the PTO. Tables VIII and IX provide the absolute and relative frequencies of the sample first by district and then by school. 
TABLE VII

CHARACTERISTICS OF SAMPLE SCHOOLS

AND NUMBER OF RESPONDENTS

\begin{tabular}{cccccc}
\hline SCHOOL & $\begin{array}{c}\text { GRADES } \\
\text { ENROLLED }\end{array}$ & $\begin{array}{c}\text { APPROXIMATE } \\
\text { ENROLLMENT }\end{array}$ & $\begin{array}{c}\text { FTE/CERT } \\
\text { STAFF }\end{array}$ & $\begin{array}{c}\text { NUMBER OF } \\
\text { RESPONDENTS }\end{array}$ & $\begin{array}{c}\% \\
\text { RETURN }\end{array}$ \\
\hline 1 & 7,8 & 400 & 25 & 23 & 92 \\
$2 *$ & $6,7,8$ & 760 & 45 & 29 & 64 \\
3 & $6,7,8$ & 219 & 16 & 9 & 56 \\
4 & 7,8 & 560 & 32 & 23 & 72 \\
5 & $6,7,8$ & 380 & 22 & 10 & 45 \\
6 & $6,7,8$ & 338 & 18 & 14 & 78 \\
7 & $6,7,8$ & 550 & 31 & 22 & 71 \\
8 & $6,7,8$ & 610 & 37 & 19 & 52 \\
$9 *$ & $6,7,8$ & 970 & 42 & 22 & 52 \\
\hline
\end{tabular}

* Year round schools 
TABLE VIII

DISTRIBUTION OF RESPONDENTS

BY SCHOOL

\begin{tabular}{cccc}
\hline SCHOOL & DISTRICT & $\begin{array}{l}\text { ABSOLUTE } \\
\text { FREQUENCY }\end{array}$ & $\begin{array}{c}\text { RELATIVE } \\
\text { FREQUENCY }\end{array}$ \\
\hline 1 & 2 & 23 & 13.5 \\
2 & 3 & 29 & 17.0 \\
3 & 4 & 9 & 5.3 \\
4 & 2 & 23 & 13.5 \\
5 & 4 & 10 & 5.8 \\
6 & 4 & 14 & 8.2 \\
7 & 1 & 22 & 12.9 \\
8 & 1 & 19 & 11.1 \\
9 & 3 & 22 & 12.9 \\
\hline
\end{tabular}

TABLE IX

DISTRIBUTION OF RESPONDENTS BY DISTRICT

\begin{tabular}{ccc}
\hline DISTRICT & $\begin{array}{l}\text { ABSOLUTE } \\
\text { FREQUENCY }\end{array}$ & $\begin{array}{l}\text { RELATIVE } \\
\text { FREQUENCY }\end{array}$ \\
\hline 1 & 41 & 24.0 \\
2 & 46 & 26.9 \\
3 & 51 & 29.8 \\
4 & 33 & 19.3 \\
\hline
\end{tabular}


Respondents

As noted earlier, the schools include grades six, seven, and eight. Some of the teachers in these schools are involved in teaching more than one of these levels; however, all of the teachers spend some time teaching grade seven or eight. This selection was chosen because of the composition of some of the schools which included only grades seven and eight. Table $x$ provides the frequency of respondents by grade level.

\section{TABLE $X$}

\section{DISTRIBUTION OF RESPONDENTS}

BY GRADE LEVEL

TAUGHT

\begin{tabular}{ccc}
$\begin{array}{l}\text { GRADE } \\
\text { LEVEL }\end{array}$ & $\begin{array}{l}\text { ABSOLUTE } \\
\text { FREQUENCY }\end{array}$ & $\begin{array}{l}\text { RELATIVE } \\
\text { FREQUENCY }\end{array}$ \\
\hline 6 & 72 & 42.1 \\
7 & 147 & 86.0 \\
8 & 146 & 85.4 \\
\hline
\end{tabular}

Description

The distribution of respondents in terms of their age, gender, years of teaching experience, years of experience in the present job, and certification level is pertinent to this study because of the indication of the literature that these elements may influence the levels of the dependent variables. 
Gender. Respondents were asked to indicate their sex. Table XI summarizes the distribution of male and female teachers in the sample.

TABLE XI

FREQUENCY DISTRIBUTION BY GENDER

\begin{tabular}{lcc}
\hline GENDER & $\begin{array}{l}\text { ABSOLUTE } \\
\text { FREQUENCY }\end{array}$ & $\begin{array}{l}\text { RELATIVE } \\
\text { FREQUENCY }\end{array}$ \\
\hline Male & 78 & 45.6 \\
Female & 93 & 54.4 \\
\hline
\end{tabular}

Age. The sample had a mean age of 40.240 years and a median age of 39.958 years. The distribution of the sample was, therefore, close to symmetrical being only slightly skewed to the positive. The mode, or most frequentiy reported age for the respondents, was 40 years. The standard deviation for age in this sample was 8.597 . Table XII provides a summary of the distribution of ages in the sample. 
TABLE XII

DISTRIBUTION OF RESPONDENTS BY AGE

\begin{tabular}{|c|c|c|c|}
\hline $\begin{array}{l}\text { AGE IN } \\
\text { YEARS }\end{array}$ & FREQUENCY & PERCENT & $\begin{array}{c}\text { CUMULATIVE } \\
\text { PERCENT }\end{array}$ \\
\hline $\begin{array}{l}23 \\
24 \\
25 \\
26 \\
27 \\
28 \\
29 \\
30 \\
31 \\
32 \\
33 \\
34 \\
35 \\
36 \\
37 \\
38 \\
39 \\
40 \\
41 \\
42 \\
43 \\
44 \\
45 \\
46 \\
47 \\
48 \\
49 \\
50 \\
51 \\
52 \\
53 \\
54 \\
55 \\
56 \\
57 \\
58 \\
59 \\
64\end{array}$ & $\begin{array}{r}1 \\
2 \\
2 \\
2 \\
3 \\
6 \\
3 \\
5 \\
8 \\
3 \\
5 \\
6 \\
7 \\
6 \\
10 \\
8 \\
3 \\
12 \\
6 \\
8 \\
6 \\
3 \\
12 \\
5 \\
2 \\
7 \\
3 \\
4 \\
4 \\
4 \\
1 \\
1 \\
5 \\
3 \\
1 \\
2 \\
1 \\
1\end{array}$ & $\begin{array}{l}0.6 \\
1.2 \\
1.2 \\
1.2 \\
1.8 \\
3.5 \\
1.8 \\
2.9 \\
4.7 \\
1.8 \\
2.9 \\
3.5 \\
4.1 \\
3.5 \\
5.8 \\
4.7 \\
1.8 \\
7.0 \\
3.5 \\
4.7 \\
3.5 \\
1.8 \\
7.0 \\
2.9 \\
1.2 \\
4.1 \\
1.8 \\
2.3 \\
2.3 \\
2.3 \\
0.6 \\
0.6 \\
2.9 \\
1.8 \\
0.6 \\
1.2 \\
0.6 \\
0.6\end{array}$ & $\begin{array}{r}0.6 \\
1.8 \\
2.9 \\
4.1 \\
5.8 \\
9.4 \\
11.1 \\
14.0 \\
18.7 \\
20.5 \\
23.4 \\
26.9 \\
31.0 \\
34.5 \\
40.4 \\
45.0 \\
46.8 \\
53.8 \\
57.3 \\
62.0 \\
65.5 \\
67.3 \\
74.3 \\
77.2 \\
78.4 \\
82.5 \\
84.2 \\
86.5 \\
88.9 \\
91.2 \\
91.8 \\
92.4 \\
95.3 \\
97.1 \\
97.7 \\
98.8 \\
99.4 \\
100.0\end{array}$ \\
\hline TOTAL & 171 & & \\
\hline
\end{tabular}


Subject Area Taught. Many of the respondents were teaching in more than one of the subject areas that are commonly found at the middle school level. Language Arts proved to be the most common. Home Arts was the least often occurring category with only six teachers involved in teaching this area. Table XIII provides a summary of the results of the data on categories of subjects taught by the respondents.

TABLE XIII

DISTRIBUTION OF RESPONDENTS

BY SUBJECT AREA

TAUGHT

\begin{tabular}{lcc}
\hline $\begin{array}{l}\text { SUBJECT AREA } \\
\text { TAUGHT }\end{array}$ & $\begin{array}{c}\text { ABSOLUTE } \\
\text { FREQUENCY }\end{array}$ & $\begin{array}{c}\text { RELATIVE } \\
\text { FREQUENCY }\end{array}$ \\
\hline Language Arts & 64 & 37.4 \\
Social Studies & 50 & 29.2 \\
Mathematics & 44 & 25.7 \\
Science & 38 & 22.2 \\
Reading & 32 & 18.7 \\
Art and/or Music & 15 & 8.8 \\
PE and/or Health & 33 & 19.3 \\
Industrial Arts & 9 & 5.3 \\
Home Arts & 6 & 3.5 \\
Other & 37 & 21.6 \\
\hline
\end{tabular}


Number of Years Taught. To obtain some of knowledge of the experiential base of the respondents, it is necessary to look at the number of years taught by those surveyed. The mean number of years taught by the respondents was 11.807, while the median was 10.800 years. As with the reported ages of the sample, the number of years taught is fairly symmetrical with only a slight positive skewing. It is sensible that the number of years taught would closely parallel the age of the individual respondents. The mode was 4 years with the maximum number of years taught being 35, while the minimum reported was 1 . The respondents were instructed to report one year even if this was their first year of teaching. The standard deviation was 7.658. Table XIV reports the summary of the years taught by the sample. 
TABLE XIV

FREQUENCY DISTRIBUTION BY NUMBER OF YEARS TAUGHT

\begin{tabular}{lrr}
\hline YEARS & ABSOLUTE FREQUENCY & RELATIVE FREQUENCY \\
\hline 1 & 10 & 5.8 \\
2 & 7 & 4.1 \\
3 & 5 & 2.9 \\
4 & 12 & 7.0 \\
5 & 10 & 5.8 \\
6 & 11 & 6.4 \\
7 & 8 & 4.7 \\
8 & 4 & 2.3 \\
9 & 6 & 3.5 \\
10 & 11 & 6.4 \\
11 & 5 & 2.9 \\
12 & 8 & 4.7 \\
13 & 5 & 2.9 \\
14 & 9 & 5.3 \\
15 & 8 & 4.7 \\
16 & 9 & 5.3 \\
17 & 1.2 \\
18 & 2 & 6.4 \\
19 & 11 & 1.2 \\
20 & 2 & 2.3 \\
21 & 4 & 1.2 \\
22 & 2 & 1.8 \\
23 & 3 & 1.8 \\
24 & 3 & 2.3 \\
25 & 4 & 1.8 \\
26 & 3 & 2.3 \\
29 & 4 & 0.6 \\
30 & 1 & 0.6 \\
31 & 1 & 1.2 \\
35 & 2 & 0.6 \\
\hline
\end{tabular}

Years in Present Position. It was determined that teachers might have changed positions and, therefore, have spent less years in their present position than years teaching. If the number of years in their present position parallels the ages and years taught by the teachers, it might indicate relatively low job turnover. The mean number of 
years in the present position was 9.392 years, while the median was 6.813 years. This resulted in a relationship that was less symmetrical than that reported for either the age or the number of years taught by the respondents. The mode was one year while the standard deviation was 7.621 . Table XV summarizes the distribution of years in the currentiy held position.

TABLE XV

FREQUENCY DISTRIBUTION BY YEARS IN PRESENT POSITION

\begin{tabular}{|c|c|c|}
\hline YEARS & ABSOLUTE FREQUENCY & RELAT IVE FREQUENCY \\
\hline $\begin{array}{l}1 \\
2 \\
3 \\
4 \\
5 \\
6 \\
7 \\
8 \\
9 \\
10 \\
11 \\
12 \\
13 \\
14 \\
15 \\
16 \\
17 \\
18 \\
19 \\
20 \\
21 \\
22 \\
23 \\
24 \\
25 \\
26 \\
30 \\
31\end{array}$ & $\begin{array}{r}22 \\
12 \\
8 \\
21 \\
11 \\
9 \\
8 \\
8 \\
1 \\
6 \\
5 \\
8 \\
2 \\
7 \\
6 \\
6 \\
1 \\
6 \\
3 \\
1 \\
2 \\
3 \\
3 \\
5 \\
2 \\
2 \\
1 \\
2\end{array}$ & $\begin{array}{r}12.9 \\
7.8 \\
4.7 \\
12.3 \\
6.4 \\
5.3 \\
4.7 \\
4.7 \\
0.6 \\
3.5 \\
2.9 \\
4.7 \\
1.2 \\
4.1 \\
3.5 \\
3.5 \\
0.6 \\
3.5 \\
1.8 \\
0.6 \\
1.2 \\
1.8 \\
1.8 \\
2.9 \\
1.2 \\
1.2 \\
0.6 \\
1.2\end{array}$ \\
\hline TOTAL & 171 & \\
\hline
\end{tabular}


Certification. Within the sample, the most frequently held certification was elementary with 72 of the respondents reporting such certification. The second most commonly reported certification was secondary (60) with 22 respondents indicating that they held both an elementary and a secondary certification. Although the sample consisted of only 171 respondents, there were 212 oregon certifications reported. This would indicate that multiple certifications were held by a large number of the respondents. Table XVI summarizes the certification of the sample.

\section{TABLE XVI}

FREQUENCY DISTRIBUTION BY CERTIFICATION

\begin{tabular}{|c|c|c|c|}
\hline CERTIFICATION & ABSOLUTE FREQUENCY & RELAT I VE & FREQUENCY \\
\hline Elementary & 72 & & 41.2 \\
\hline Secondary & 60 & & 35.1 \\
\hline Both & 22 & & 12.9 \\
\hline Specialist & 55 & & 32.2 \\
\hline Administrative & 0 & & 00.0 \\
\hline Other & 3 & & 1.8 \\
\hline
\end{tabular}

Gender and Certification. Table XVII summarizes the relationship between the gender of individuals and the number of certifications possessed, and indicates that secondary certification is slightly more prevalent among females 
than males, while elementary certification is consistent with the gender distribution in the sample.

\section{TABLE XVII}

CERTIFICATION AS RELATED

TO GENDER

\begin{tabular}{|c|c|c|c|c|}
\hline \multirow[t]{2}{*}{ GENDER } & \multicolumn{2}{|c|}{ MALE } & \multicolumn{2}{|c|}{ FEMALE } \\
\hline & $\begin{array}{l}\text { Absolute } \\
\text { Frequency }\end{array}$ & $\begin{array}{l}\text { Relative } \\
\text { Frequency }\end{array}$ & $\begin{array}{l}\text { Absolute } \\
\text { Frequency }\end{array}$ & $\begin{array}{l}\text { Relative } \\
\text { Frequency }\end{array}$ \\
\hline Respondents & 78 & 45.6 & 93 & 54.4 \\
\hline $\begin{array}{l}\text { Elementary } \\
\text { Certification }\end{array}$ & 32 & 44.4 & 40 & 55.6 \\
\hline $\begin{array}{l}\text { Secondary } \\
\text { Certification }\end{array}$ & 24 & 40.0 & 36 & 60.0 \\
\hline $\begin{array}{l}\text { Both Elementary } \\
\text { and Secondary } \\
\text { Certification }\end{array}$ & 14 & 63.6 & 8 & 36.4 \\
\hline Other/Specialist & 21 & 36.2 & 37 & 63.8 \\
\hline TOTAL & 169 & & 214 & \\
\hline
\end{tabular}

Graduates of oregon Institutions. It is logical that since this study was conducted in the Portland metropolitan region that the respondents would tend to be more frequently graduates of universities and colleges located in that geographical area. Specifically, it was found that the greatest number of respondents held degrees from Portland State University. Other frequently reported institutions included Lewis and Clark College, the University of Oregon, and 
Oregon State University. Table XVIII reports the distribution of the responses regarding graduation from oregon institutions of higher learning.

TABLE XVIII

FREQUENCY OF RESPONDENTS WHO ARE GRADUATES

OF OREGON INSTITUTIONS OF

OF HIGHER EDUCATION

\begin{tabular}{lcc}
\hline INSTITUTION & $\begin{array}{c}\text { ABSOLUTE } \\
\text { FREQUENCY }\end{array}$ & $\begin{array}{c}\text { RELATIVE } \\
\text { FREQUENCY }\end{array}$ \\
\hline Portland State & 56 & 32.7 \\
University of oregon & 26 & 15.2 \\
Oregon State & 24 & 14.0 \\
Willamette & 3 & 1.8 \\
Lewis and Clark & 26 & 15.3 \\
University of Portland & 7 & 4.1 \\
WoSC & 18 & 10.6 \\
Other & 12 & 7.1 \\
\hline
\end{tabular}

Middle School Training. Since many of the experts on middle schools supported the trend to provide training for middle school teachers, it was deemed necessary to look at the levels of training that had been obtained by the respondents to the questionnaire. The teachers in this study reported relatively low levels of training specifically designed to prepare them for middle school teaching. Only 60 of the respondents reported any form of training. Some of 
them reported training that consisted of student teaching at the middle school level prior to taking a job as a teacher of that level. Table XIX summarizes the distribution of middle school training among the respondent teachers.

\section{TABLE XIX}

FREQUENCY DISTRIBUTION BY

MIDDLE SCHOOL

TRAINING

\begin{tabular}{lcc}
\hline LEVEL OF & ABSOLUTE & RELATIVE \\
TRAINING & FREQUENCY & FREQUENCY \\
\hline Undergraduate & 35 & 20.6 \\
Graduate & 14 & 8.2 \\
Both & 11 & 6.5 \\
None & 111 & 64.7 \\
\hline
\end{tabular}

Summary. The findings indicate that the sample is rather evenly distributed among males and females and elementary and secondary teaching certifications. More females hold secondary certification than males. Over 25 percent of the sample is within the first three years of their teaching experience. A high number of degrees (172) have been obtained by respondents at Oregon institutions of higher learning, while a low relative frequency (35.3\%) report any training for middle school teaching. 


\section{Results of the PTO}

Scoring of the PTO

The PTO consists of 100 items that are divided among ten subscales. These ten scales are Teacher Rapport with the Principal, Satisfaction with Teaching, Rapport Among Teachers, Teacher Salary, Teacher Load, Curriculum Issues, Teacher Status, Community Support of Education, School Facilities and Services, and Community Pressures (see Appendix A for a definition of each subscale). Table $X X$ indicates the assignment of items to each of the subscales.

Respondents were asked to read each question quickly and respond to the questions on a Likert-type scale consisting of four possible responses: Agree, Probably Agree, Probably Disagree, and Disagree. The items were scored from four to one in value. Agree received a score of four while Disagree received a score of one. There were some items that were negative; i.e., an answer of Agree would be assigned a value of one, while an answer of Disagree would be valued at four. These items were: $1,5,6,8,10,11,14$, $18,25,30,31,34,40,42,45,54,56,60,71,72,76,79$, $81,85,98$, and 99. The scoring is designed to give a higher score to those with higher levels of satisfaction with the areas concerned on each subscale and a higher total score indicating a higher level of morale for the respondent. 
TABLE XX

ASSIGNMENT OF PTO ITEMS TO SUBSCALES

\begin{tabular}{ll}
\hline SUBSCALE & \multicolumn{1}{c}{ ITEM } \\
\hline $\begin{array}{l}\text { Teacher Rapport with } \\
\text { Principal }\end{array}$ & $2,3,5,7,12,33,38,41,43$, \\
& $44,61,62,69,70,72,73,74$, \\
$\begin{array}{l}\text { Satisfaction with } \\
\quad \text { Teaching }\end{array}$ & $19,24,26,27,29,30,46,47$, \\
& $50,51,56,58,60,76,78,82$, \\
Rapport Among Teachers & $83,86,89,100$ \\
& $18,22,23,28,48,52,53,54$, \\
Teacher Salary & $55,77,80,84,87,90$ \\
Teacher Load & $4,9,32,36,39,65,75$ \\
Curriculum Issues & $1,6,8,10,11,14,31,34$, \\
Teacher Status & $40,42,45$ \\
Community Support of & $17,20,25,79,88$ \\
Education & $13,15,35,37,63,64,68,71$ \\
School Facilities and & $66,67,94,96,97$ \\
Services &
\end{tabular}

Summary of the Results for the Total Sample

Table XXI provides the results from the total sample on all of the scores of the PTO. The scores that are of most importance to this study are those of Rapport with the Principal, Satisfaction with Teaching, Rapport Among Teachers, Status, and Morale. Although reported, the other subscale scores will not be discussed in detail. 
Morale

Since there are a total of 100 questions on the PTO, it is possible to obtain a total score for Morale of 400 . The mean sample score was 308.368 with a median of 311.667 which would indicate a relatively symmetrical relationship with only a slight negative skewing. The range of scores for the total sample was 168 with the lowest total score being 226 and the highest 394 . The standard deviation was 35.648 .

Rapport with the Principal

The mean score for the sample on the subscale of Rapport with the Principal was 63.392 while the median was 65.350. This is again relatively symmetrical, however, there is a slight negative skewing in this score, also. The range of scores was 55.000 with the highest score being 80 of a possible 80 while the lowest score was 25 . The standard deviation was 12.383.

\section{Rapport Among Teachers}

The mean score on this subscale was 46.199 while the median was 46.531. Although slightly skewed to the left, this relationship is consistent with the other rapport measurement. The range of the sample response is 29.000 with the lowest score being 27.000 out of a possible 56.000, 
while the hignest score was 56.000. The standard deviation was 6.031 .

Satisfaction with Teaching

The total possible on this subscale was 80.000 , just as it was for Rapport with the Principal. The sample mean for this subscale was 65.503 with a median score of 66.143 . Again there was the slightly negative skewing that occurred with the other subscales as well as the total Morale results. The range on this scale was 43.000 with the high being 80.000 and the lowest reported score being 37.000 . The standard deviation was 9.444 .

Status

With a total possible score of 32.000 on this subscale of the PTO, the mean reported score was 20.123 with a median of 19.615. Unlike the prior subscores, Teacher Status is skewed somewhat to the positive while being relatively symmetrical. The range was 24.000 with a high score of 29.000 and a low of 8.000 . The standard deviation was 5.196 . 
TABLE XXI

RESULTS FOR THE TOTAL SAMPLE ON

THE SCALES OF THE PTO

\begin{tabular}{|c|c|c|c|c|}
\hline $\begin{array}{r}\text { TOT } \\
\text { PC }\end{array}$ & $\begin{array}{l}A L \text { SCORE } \\
\text { OSSIBLE }\end{array}$ & MEDIAN & MEAN & $\begin{array}{l}\text { STANDARD } \\
\text { DEVIATION }\end{array}$ \\
\hline $\begin{array}{l}\text { Rapport with } \\
\text { the Principal }\end{array}$ & 80 & 65.350 & 63.392 & 12.383 \\
\hline $\begin{array}{l}\text { Satisfaction with } \\
\text { Teaching }\end{array}$ & 80 & 66.143 & 65.503 & 9.444 \\
\hline $\begin{array}{l}\text { Rapport Among } \\
\text { Teachers }\end{array}$ & 56 & 46.531 & 46.199 & 6.031 \\
\hline Salary & 28 & 18.667 & 18.544 & 4.019 \\
\hline Teacher Load & 44 & 33.769 & 33.327 & 5.615 \\
\hline Curriculum Issues & 20 & 15.914 & 15.450 & 3.425 \\
\hline $\begin{array}{l}\text { Comunity Support } \\
\text { of Education }\end{array}$ & 20 & 13.179 & 13.117 & 3.462 \\
\hline Teacher Status & 32 & 19.615 & 20.123 & 5.196 \\
\hline $\begin{array}{l}\text { School Facilities } \\
\text { and Services }\end{array}$ & 20 & 16.817 & 16.327 & 2.873 \\
\hline Community Pressures & 20 & 16.659 & 16.386 & 2.416 \\
\hline Morale & 400 & 311.667 & 308.368 & 35.648 \\
\hline
\end{tabular}




\section{Summary of the Results for Each School}

Looking at the sample results on a macro level provides one view of the data, however, it is possible that the results of one school which deviates significantly might be effecting the full sample. In order to provide a picture of the individual school, the obtained data is provided on a school by school basis for four of the factors of the PTO: Rapport with the Principal; Satisfaction with Teaching; Rapport Among Teachers; Teacher Status; and Morale.

School 1

The results on Rapport with the Principal for this school were a mean of 67.478 and a median of 69.000 with considerable negative skewing $(-1.629)$. The range was 45.000 with a high of 80 and a low of 35 . The standard deviation of this subscore was 10.582 . Although also negatively skewed, Satisfaction with Teaching was much more symmetrical with a mean of 64.438 and a median of 65.750 . The standard deviation was 8.584. Rapport Among Teachers was also relatively symmetrical with slight negative skewing. The mean of this subscale for School 1 was 48.913 , and the median was 49.000. Teacher Status, on the other hand, was somewhat positively skewed with a mean of 18.696 and a median of 18.333. The total score for Morale was only 
slightly negatively skewed and the mean was 309.043 , while the median was 314.000 with a standard deviation of 35.037 . (See Appendix B for remaining subscale scores by school.) Table XXII provides these results.

TABLE XXI I

RESULTS FOR SCHOOL 1 ON SELECT SCALE OF THE PTO

\begin{tabular}{lccrr}
\hline $\begin{array}{l}\text { SCALE } \\
\begin{array}{l}\text { Rapport with } \\
\text { the Principal }\end{array}\end{array}$ & $\begin{array}{c}\text { TOTAL SCORE } \\
\text { POSSIBLE }\end{array}$ & MEDIAN & MEAN & $\begin{array}{r}\text { STANDARD } \\
\text { DEVIATION }\end{array}$ \\
$\begin{array}{l}\text { Satisfaction with } \\
\text { Teaching }\end{array}$ & 80 & 69.000 & 67.478 & 10.582 \\
$\begin{array}{l}\text { Rapport Among } \\
\text { Teachers }\end{array}$ & 56 & 65.750 & 64.348 & 8.584 \\
$\begin{array}{l}\text { Teacher Status } \\
\text { Morale }\end{array}$ & 32 & 49.000 & 48.913 & 5.169 \\
\hline
\end{tabular}

\section{School 2}

of these results, the least symmetrical was that of Teacher Status which had a mean of 18.552 and a median of 17.417 and was skewed to the positive. The standard deviation for this subscale was 5.054. The mean of Rapport with the Principal was among the four lowest for any of the schools at 61.750 with a standard deviation of 12.890. Satisfaction was quite symmetrical with a mean of 65.069 , a median of 68.000, and a standard deviation of 10.243. Rapport 
Among Teachers, although skewed slightly to the left, was quite symmetrical with a mean of 45.931 and a median of 46.417. The Morale score for this building was one of the lowest with a mean of 303.345 and a standard deviation of 36.937. The range on this score was 160 with a high of 341 and a low of 226 . These results are presented in Table $X X I I I$.

TABLE XXIII

RESULTS FOR SCHOOL 2 ON

SELECT SCALES OF

THE PTO

\begin{tabular}{lccrr}
\hline $\begin{array}{l}\text { SCALE } \\
\begin{array}{l}\text { Rapport with } \\
\text { the Principal }\end{array}\end{array}$ & $\begin{array}{c}\text { TOTAL SCORE } \\
\text { POSSIBLE }\end{array}$ & MEDIAN & MEAN & $\begin{array}{r}\text { STANDARD } \\
\text { DEVIATION }\end{array}$ \\
$\begin{array}{l}\text { Satisfaction with } \\
\text { Teaching }\end{array}$ & 80 & 61.750 & 59.826 & 12.890 \\
$\begin{array}{l}\text { Rapport Among } \\
\text { Teachers }\end{array}$ & 56 & 68.000 & 65.069 & 10.234 \\
$\begin{array}{l}\text { Teacher Status } \\
\text { Morale }\end{array}$ & 32 & 46.417 & 45.931 & 5.725 \\
\hline
\end{tabular}

School 3

As with several previous results, School 3 seemed to show some negative skewing of some of the scores particularly on the subscales of Rapport with the Principal which had a mean of 65.778 and a median of $71.000(-0.916)$. The subscales of Satisfaction with Teaching (mean $=69.11$ ) 
Rapport Among Teachers (mean $=51.889)$, and Teacher Status $($ mean $=20,000)$, as may be seen in Table XXIV, were all relatively symmetrical and skewed only slightly to the right. The total score of Morale (mean $=320.556$ ) had a standard deviation of 21.518 .

TABLE XXIV

RESULTS FOR SCHOOL 3 ON

SELECT SCALES OF

THE PTO

\begin{tabular}{lcrrr}
\hline SCALE & $\begin{array}{c}\text { TOTAL SCORE } \\
\text { POSSIBLE }\end{array}$ & MEDIAN & MEAN & $\begin{array}{r}\text { STANDARD } \\
\text { DEVIATION }\end{array}$ \\
\hline $\begin{array}{l}\text { Rapport with } \\
\text { the Principal }\end{array}$ & 80 & 71.000 & 65.778 & 11.200 \\
$\begin{array}{l}\text { Satisfaction with } \\
\text { Teaching }\end{array}$ & 80 & 69.000 & 69.111 & 4.649 \\
$\begin{array}{l}\text { Rapport Among } \\
\text { Teachers }\end{array}$ & 56 & 50.250 & 51.889 & 3.257 \\
$\begin{array}{l}\text { Teacher Status } \\
\text { Morale }\end{array}$ & 32 & 19.250 & 20.000 & 2.915 \\
\hline
\end{tabular}

School 4

This school had the highest reported total scale score for the PTO. The Morale score for School 4 had a mean of 322.870 and was relatively symmetrical. The standard deviation of this score was 39.052. The range was 135.00 with a high of 394.00 and a low of 259.000. Although the remainder of the scores were moderately high, it was the consistency 
of the scores that seemed to have resulted in the highest total scale score. The mean for Rapport with the Principal was 65.391 with a standard deviation of 11.723 . The mean of Satisfaction with Teaching was 65.565 with a standard deviation of 10.215. Rapport Among Teachers had a mean of 47.696 and a standard deviation of 5.346, while Teacher Status was among the higher ones for this subscale score with a mean of 21.783. The subscale scores were fairly consistently skewed to the right with the exception of Rapport Among Teachers which was slightly skewed to the negative side. See Table $X X V$ for these results.

TABLE XXV

RESULTS FOR SCHOOL 4 ON

SELECT SCALES OF

THE PTO

\begin{tabular}{lccrr}
\hline $\begin{array}{l}\text { SCALE } \\
\begin{array}{l}\text { Rapport with } \\
\text { the Principal }\end{array}\end{array}$ & $\begin{array}{c}\text { TOTAL SCORE } \\
\text { POSSIBLE }\end{array}$ & MEDIAN & MEAN & $\begin{array}{r}\text { STANDARD } \\
\text { DEVIATION }\end{array}$ \\
$\begin{array}{l}\text { Satisfaction with } \\
\text { Teaching }\end{array}$ & 80 & 65.125 & 65.391 & 11.723 \\
$\begin{array}{l}\text { Rapport Among } \\
\text { Teachers }\end{array}$ & 56 & 64.750 & 65.565 & 10.215 \\
$\begin{array}{l}\text { Teacher Status } \\
\text { Morale }\end{array}$ & 32 & 48.000 & 47.696 & 5.346 \\
\hline
\end{tabular}




\section{School 5}

This school had a high score on Satisfaction with Teaching. The mean of 70.100 and median of 74.500 were the highest results among the nine schools. There was considerable negative skewing $(-1.594)$ in these results and a standard deviation of 8.825. Although this school produced the highest Satisfaction with Teaching score, it was only the third highest Morale score among the schools with a mean of 317.200. Rapport with the Principal had a mean of 58.000 with a standard deviation of 5.944. Rapport Among Teachers had a mean of 49.100 and, like the other Rapport score, was skewed slightly to the negative. Teacher Status had a mean of 21.900 and a standard deviation of 3.071 .

\section{TABLE XXVI}

RESULTS FOR SCHOOL 5 ON

SELECT SCALES OF

THE PTO

\begin{tabular}{lcrrr}
\hline $\begin{array}{l}\text { SCALE } \\
\begin{array}{l}\text { Rapport with } \\
\text { the Principal }\end{array}\end{array}$ & $\begin{array}{c}\text { TOTAL SCORE } \\
\text { POSSIBLE }\end{array}$ & MEDIAN & MEAN & $\begin{array}{c}\text { STANOARD } \\
\text { DEVIATION }\end{array}$ \\
$\begin{array}{l}\text { Satisfaction with } \\
\text { Teaching }\end{array}$ & 80 & 58.500 & 58.000 & 6.944 \\
$\begin{array}{l}\text { Rapport Among } \\
\text { Teachers }\end{array}$ & 56 & 74.500 & 70.100 & 8.825 \\
$\begin{array}{l}\text { Teacher Status } \\
\text { Morale }\end{array}$ & 32 & 21.500 & 21.900 & 3.071 \\
\hline
\end{tabular}


School 6

This school had a mean of 70.357 with a standard deviation of 8.082 , slightly skewed to the left. The total scale score for Morale had a mean of 305.357 with a standard deviation of 40.355 . These results were quite symmetrical. Satisfaction with Teaching was quite symmetrical also with a mean of 66.286 and a median of 45.500 was skewed considerably more to the left $(-1.116)$. These results are provided in Table XXVII.

\section{TABLE XXVII}

RESULTS FOR SCHOOL 6 ON SELECT SCALES OF

THE PTO

\begin{tabular}{lccrr}
\hline SCALE & $\begin{array}{c}\text { TOTAL SCORE } \\
\text { POSSIBLE }\end{array}$ & MEDIAN & MEAN & $\begin{array}{r}\text { STANDARD } \\
\text { DEVIATION }\end{array}$ \\
\hline $\begin{array}{l}\text { Rapport with } \\
\text { the Principal }\end{array}$ & 80 & 70.500 & 70.357 & 8.082 \\
$\begin{array}{l}\text { Satisfaction with } \\
\text { Teaching }\end{array}$ & 80 & 66.500 & 66.286 & 7.600 \\
$\begin{array}{l}\text { Rapport Among } \\
\text { Teachers }\end{array}$ & 56 & 45.500 & 45.929 & 6.403 \\
$\begin{array}{l}\text { Teacher Status } \\
\text { Morale }\end{array}$ & 32 & 18.500 & 18.714 & 6.281 \\
\hline
\end{tabular}

School 7

The teachers in this school perceived their relative status as being higher than any of the teachers in the other 
buildings surveyed. As may be seen in Table XXVIII, the mean for Teacher Status was 23.591 with a standard deviation of 4.284. Although both of the Rapport subscale scores were skewed in a negative direction, the results were relatively symmetrical with the mean for Rapport with the Principal being 59.136 and the mean for Rapport Among Teachers 45.500. The mean for Satisfaction with Teaching was 65.364 with a standard deviation of 9.550. The total scale score for Morale had a mean of 313.864 with a standard deviation of 29.721 .

\section{TABLE XXVIII}

RESULTS FOR SCHOOL 7 ON

SELECT SCALES OF

THE PTO

\begin{tabular}{lccrc}
\hline $\begin{array}{l}\text { SCALE } \\
\begin{array}{l}\text { Rapport with } \\
\text { the Principal }\end{array}\end{array}$ & $\begin{array}{c}\text { TOTAL SCORE } \\
\text { POSSIBLE }\end{array}$ & MEDIAN & MEAN & $\begin{array}{c}\text { STANDARD } \\
\text { DEVIATION }\end{array}$ \\
$\begin{array}{l}\text { Satisfaction with } \\
\text { Teaching }\end{array}$ & 80 & 62.000 & 59.136 & 15.520 \\
$\begin{array}{l}\text { Rapport Among } \\
\text { Teachers }\end{array}$ & 56 & 65.500 & 65.364 & 9.550 \\
$\begin{array}{l}\text { Teacher Status } \\
\text { Morale }\end{array}$ & 32 & 46.500 & 45.500 & 5.680 \\
\hline
\end{tabular}


School 8

Rapport with the Principal had a mean of 64.947 and median of 64.750. The standard deviation of this subscale score was 3.156 and, while negatively skewed, was more symmetrical than the scores for Satisfaction with Teaching with a mean of 64.526 and median of 65.000 . The subscale score for Rapport Among Teachers was a mean of 43.474 with a standard deviation of 5.948. Teacher status was quite symmetrical with a mean of 19.368 and median of 19.083. The Morale score was 302.316 with a standard deviation of 38.041 . The results are presented in Table XXIX.

TABLE XXIX

RESULTS FOR SCHOOL 8 ON SELECT SCALES OF

THE PTO

\begin{tabular}{lccrr}
\hline SCALE & $\begin{array}{c}\text { TOTAL SCORE } \\
\text { POSSIBLE }\end{array}$ & MEDIAN & MEAN & $\begin{array}{r}\text { STANDARD } \\
\text { DEVIATION }\end{array}$ \\
\hline $\begin{array}{l}\text { Rapport with } \\
\text { the Principal }\end{array}$ & 80 & 64.750 & 64.947 & 9.449 \\
$\begin{array}{l}\text { Satisfaction with } \\
\text { Teaching }\end{array}$ & 80 & 65.000 & 64.526 & 11.047 \\
$\begin{array}{l}\text { Rapport Among } \\
\text { Teachers }\end{array}$ & 56 & 43.000 & 43.474 & 5.948 \\
$\begin{array}{l}\text { Teacher Status } \\
\text { Morale }\end{array}$ & 32 & 19.083 & 19.368 & 5.058 \\
\hline
\end{tabular}


School 9

The mean score for Rapport with the Principal for School 9 was 61.682 and with a standard deviation of 3.156 . The mean score for Teacher Status was 19.273 with a standard deviation of 5.382. Morale was the lowest reported among the schools with a mean of 291.773 and standard deviation of 38.386. Satisfaction with Teaching was also the lowest reported with a mean of 64.136 and standard deviation of 10.091 which may be seen in Table $X X X$.

TABLE $X X X$

RESULTS FOR SCHOOL 9 ON

SELECT SCALES OF

THE PTO

\begin{tabular}{lcccc}
\hline SCALE & $\begin{array}{c}\text { TOTAL SCORE } \\
\text { POSSIBLE }\end{array}$ & MEDIAN & MEAN & $\begin{array}{c}\text { STANDARD } \\
\text { DEVIATION }\end{array}$ \\
\hline $\begin{array}{l}\text { Rapport with } \\
\text { the Principal }\end{array}$ & 80 & 65.500 & 61.682 & 3.156 \\
$\begin{array}{l}\text { Satisfaction with } \\
\text { Teaching }\end{array}$ & 80 & 65.250 & 64.136 & 10.091 \\
$\begin{array}{l}\text { Rapport Among } \\
\text { Teachers }\end{array}$ & 56 & 43.167 & 41.727 & 6.112 \\
$\begin{array}{l}\text { Teacher Status } \\
\text { Morale }\end{array}$ & 32 & 18.500 & 19.273 & 5.382 \\
\hline
\end{tabular}

Summary of Results by School and District for Satisfaction with Teaching and Morale

As well as a particular school's results creating an impact on the overall sample, it is possible that a full 
district might have a similar effect on the sample. For this reason, the resultant data on the subscale of Satisfaction with Teaching and the total score for Morale are reported by school and district.

Satisfaction with Teaching. The mean scores by district ranged from 64.67 (District 3) to 68.21 (District 4) with the greatest standard deviation being 10.09 for the lowest mean satisfaction score (District 3 ).

TABLE $X X X I$

SATISFACTION WITH TEACHING SCORES BY DISTRICT

\begin{tabular}{llr}
\hline DISTRICT & MEAN & $\begin{array}{l}\text { STANDARD } \\
\text { DEVIATION }\end{array}$ \\
\hline 1 & 64.98 & 8.58 \\
2 & 64.96 & 9.35 \\
3 & 64.67 & 10.09 \\
4 & 68.21 & 7.33 \\
\hline
\end{tabular}

TABLE XXXII

SATISFACTION WITH TEACHING SCORES BY SCHOOL

\begin{tabular}{llr}
\hline SCHOOL & MEAN & $\begin{array}{c}\text { STANDARD } \\
\text { DEVIATION }\end{array}$ \\
\hline 1 & 64.35 & 8.58 \\
2 & 65.07 & 10.24 \\
3 & 69.11 & 4.65 \\
4 & 65.57 & 10.22 \\
5 & 70.10 & 8.82 \\
6 & 66.29 & 7.60 \\
7 & 65.36 & 9.55 \\
8 & 64.53 & 11.05 \\
9 & 64.14 & 10.09 \\
\hline
\end{tabular}




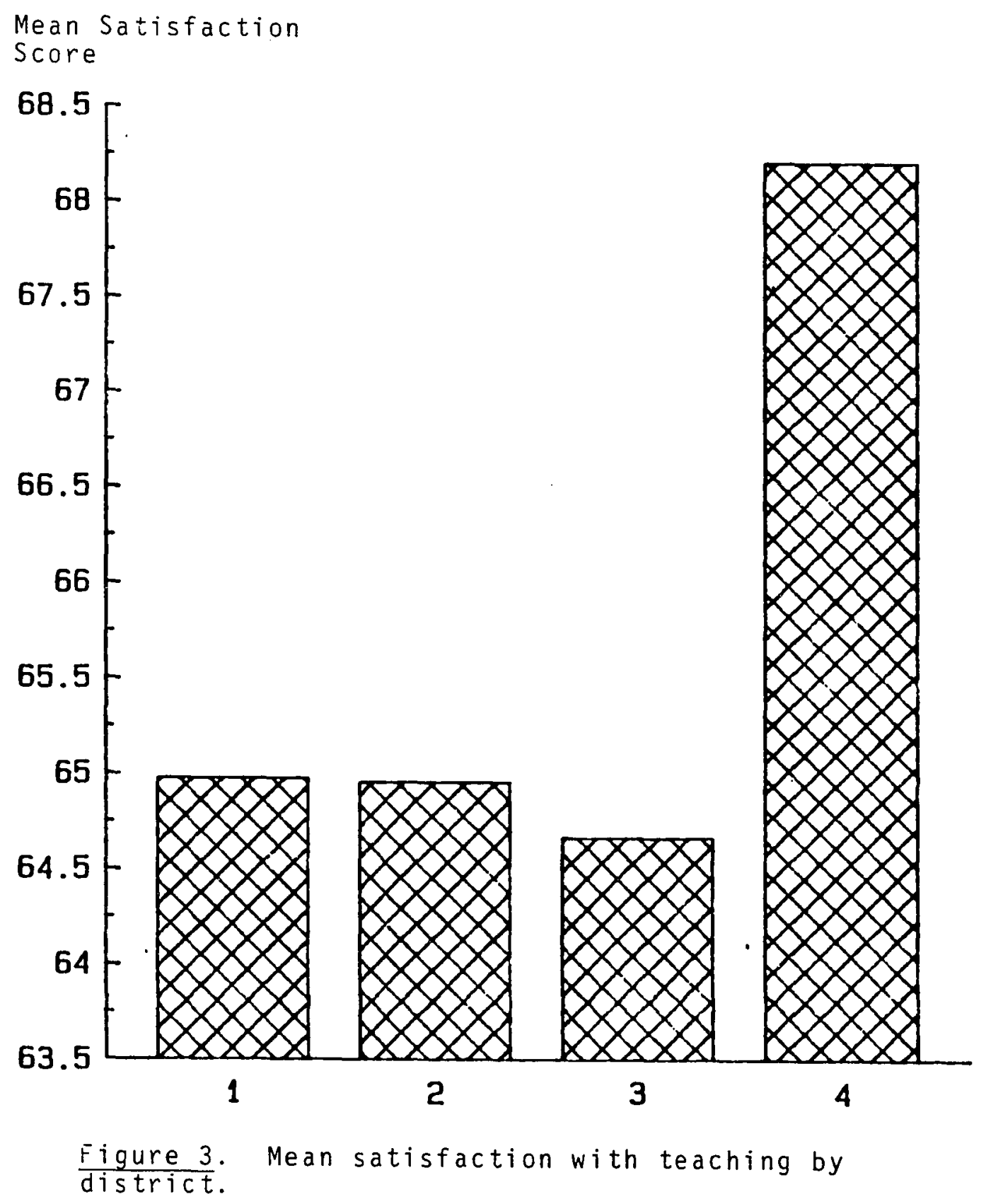




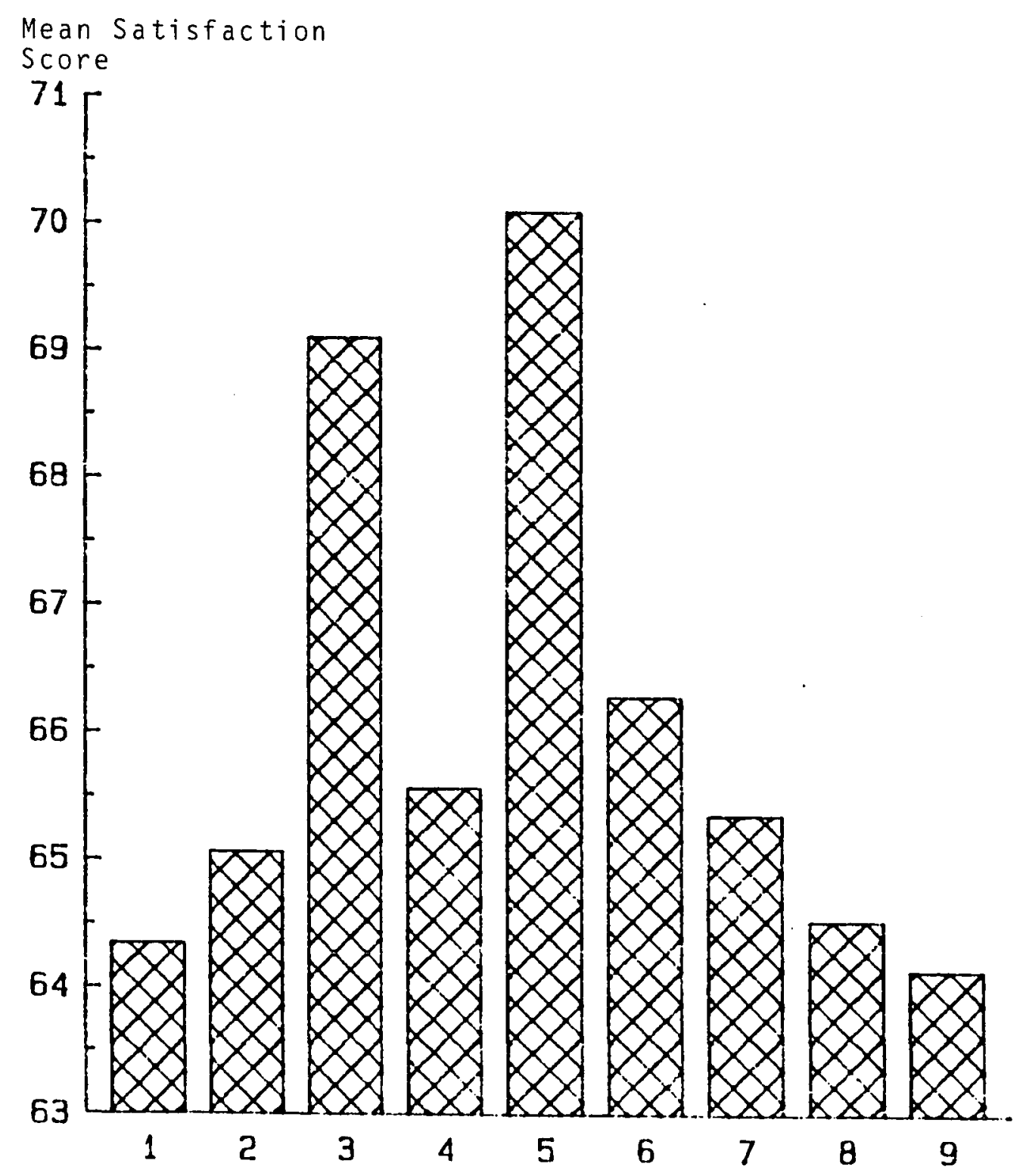

Figure 4. Mean satisfaction with teaching by school. 
Morale. District morale scores indicated that, although the highest mean levels of Satisfaction with Teaching were found in District 4 , the highest mean morale score was for District 2 (315.96). Again, the lowest mean score (298.35) with the highest standard deviation was in District 3.

It is well to review the school assignment by district to assist in interpreting this data:

$$
\begin{aligned}
& \text { District } 1 \text { - Schools: } 7,8 \\
& \text { District } 2 \text { - Schools: } 1,4 \\
& \text { District } 3 \text { - Schools: } 2,9 \\
& \text { District } 4 \text { - Schools: } 3,5,6
\end{aligned}
$$

TABLE XXXIII

MORALE SCORES BY DISTRICT

\begin{tabular}{lcc}
\hline DISTRICT & MEAN & $\begin{array}{c}\text { STANDARD } \\
\text { DEVIATION }\end{array}$ \\
\hline 1 & 308.51 & 33.90 \\
2 & 315.96 & 37.34 \\
3 & 298.35 & 37.63 \\
4 & 313.09 & 29.58 \\
\hline
\end{tabular}


TABLE XXXIV

MORALE SCORES BY

SCHOOLS

\begin{tabular}{lll}
\hline DISTRICT & MEAN & $\begin{array}{c}\text { STANDARD } \\
\text { DEVIATION }\end{array}$ \\
\hline 1 & 309.04 & 35.04 \\
2 & 303.34 & 36.94 \\
3 & 320.56 & 21.52 \\
4 & 322.87 & 39.05 \\
5 & 317.20 & 13.40 \\
6 & 305.36 & 40.36 \\
7 & 313.86 & 29.72 \\
8 & 302.32 & 38.04 \\
9 & 291.77 & 38.39 \\
\hline
\end{tabular}

Summary. In summary, the difference that exists between schools and districts in the area of Satisfaction with Teaching and Morale must be pointed out. It may be seen that there was considerable separation between the high means and low means in these cases.

Relationship of PTO Subscales and Biographical Data

Satisfaction with Teaching

A number of hypotheses in this study addressed relationships of biographical characteristics to the dependent variable Satisfaction with Teaching. 


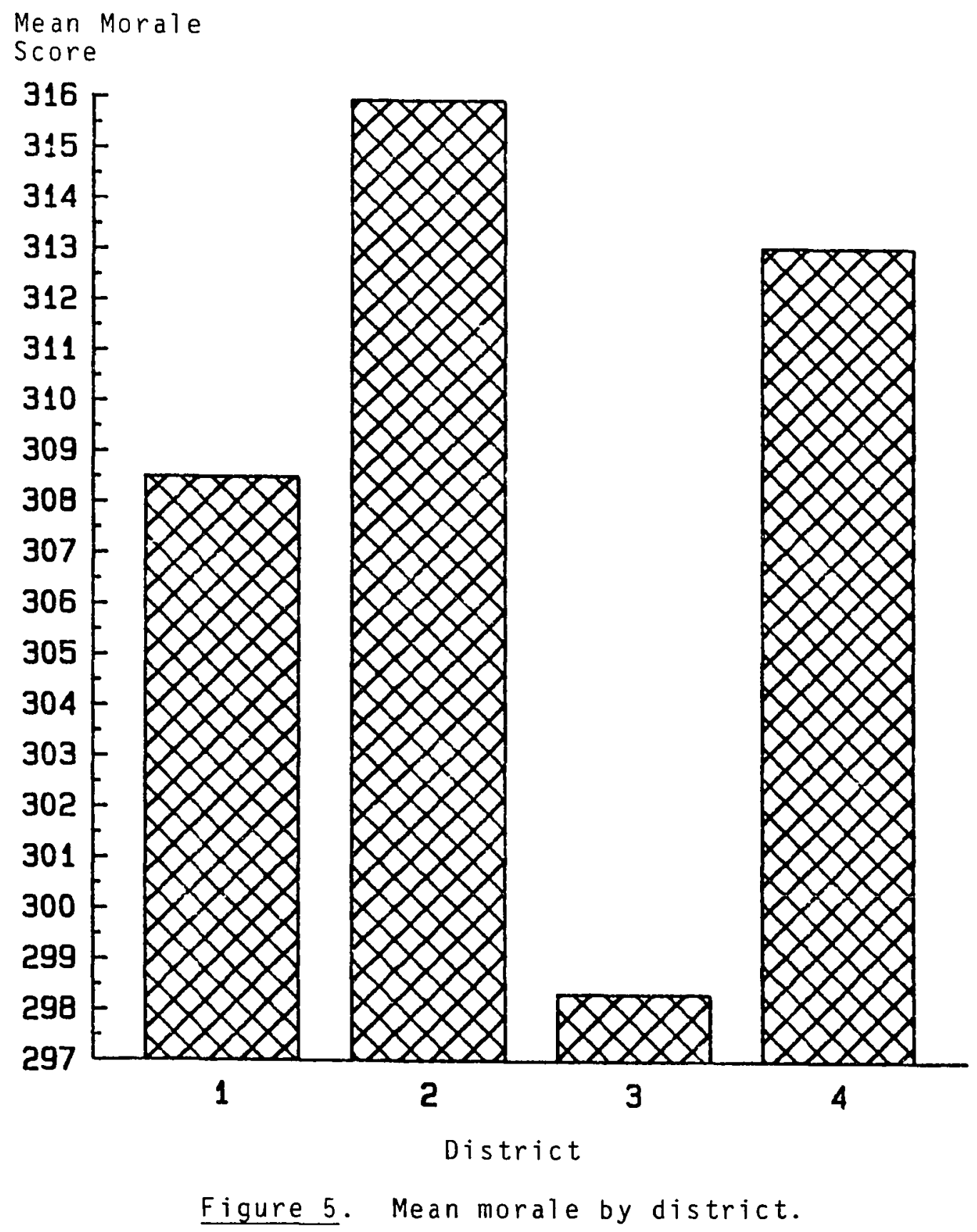




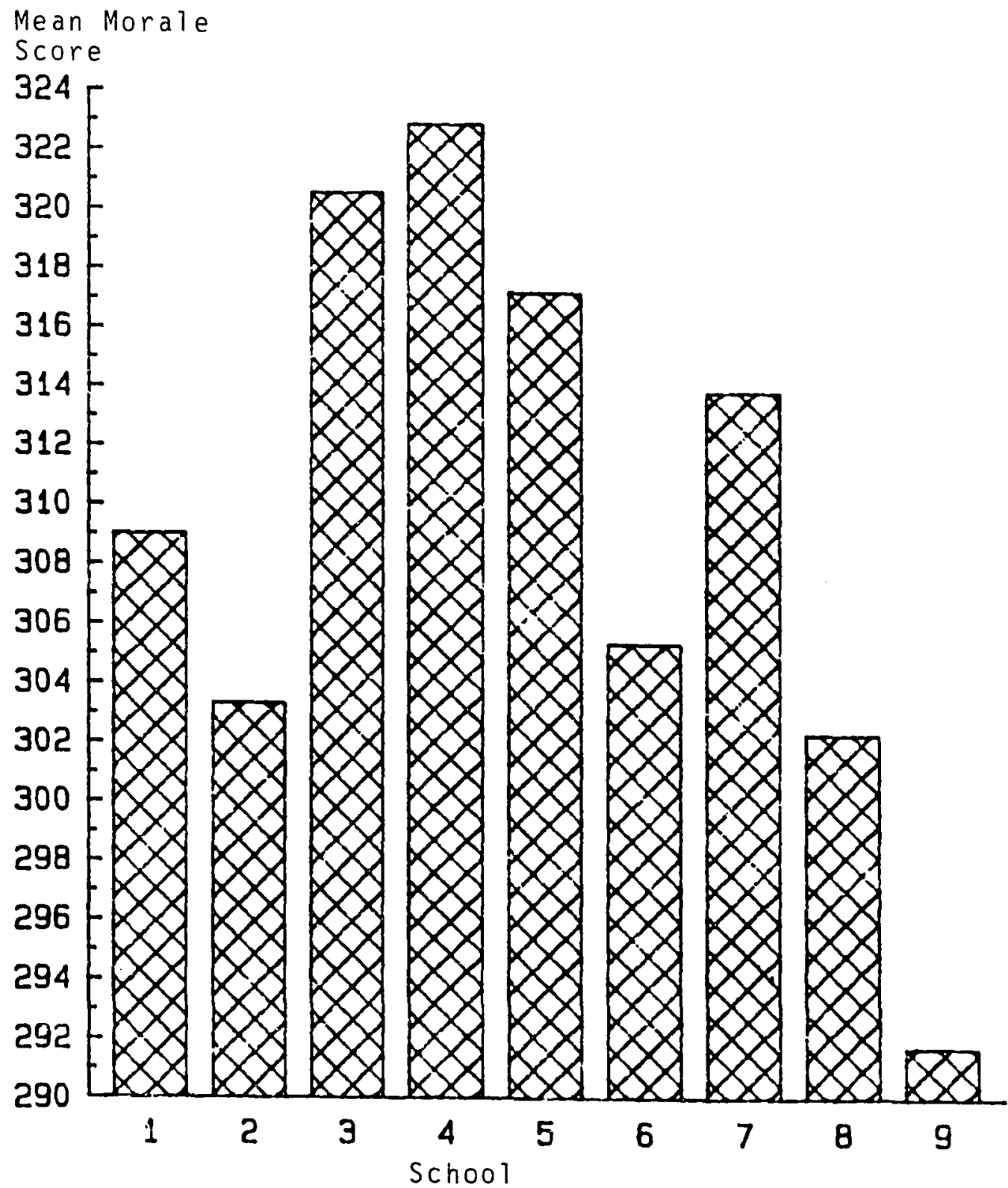

Figure 6. Mean morale score by school. 
Relationship to Gender. It is important to look at the distribution of gender throughout the schools in the sample to see if any one school was predominantly male or female and might have swayed the sample results. Table XXXV summarizes these data and indicates that, although some schools such as number 2 had a greater proportion of females, the overall sample was $46 \%$ male and $54 \%$ female. There was a fairly even distribution of males and females in the sample.

TABLE $X X X V$

DISTRIBUTION OF GENDER

BY SCHOOL

\begin{tabular}{lrc}
\hline SCHOOL & MALE & FEMALE \\
\hline 1 & 11 & 12 \\
2 & 10 & 19 \\
3 & 4 & 5 \\
4 & 12 & 11 \\
5 & 6 & 4 \\
6 & 7 & 7 \\
7 & 11 & 11 \\
8 & 9 & 10 \\
9 & 8 & 14 \\
\hline TOTALS & 78 & 93 \\
\hline
\end{tabular}


Hypothesis 4: Females in the sample will have higher scores on the subscale satisfaction with teaching than males.

The mean levels of Satisfaction with Teaching indicate that females were more satisfied with their profession than were the males in this sample. The mean level of satisfaction score for females may be seen in Table XXXVI. (See Figure 7.)

\section{TABLE XXXVI}

\section{LEVELS OF SATISFACTION \\ BY GENDER}

\begin{tabular}{lccc} 
GENDER & MEAN & $\begin{array}{l}\text { STANDARD } \\
\text { DEVIATION }\end{array}$ & $\frac{n}{78}$ \\
\hline Male & 63.69 & 9.84 & 93 \\
Female & 67.02 & 8.87 & 9 \\
\hline
\end{tabular}

As noted by Charters (1970) and Lortie (1975), there continues to be a relationship between the gender of the teacher and the level of satisfaction. In order to test the significance of this relationship, a univariate analysis of variance was performed with alpha set at .05 . Sex was the independent variable; Satisfaction with Teaching the dependent variable. The relationship was found to be significant at the .03 level. The results of this analysis are seen in Table XXXVII. 


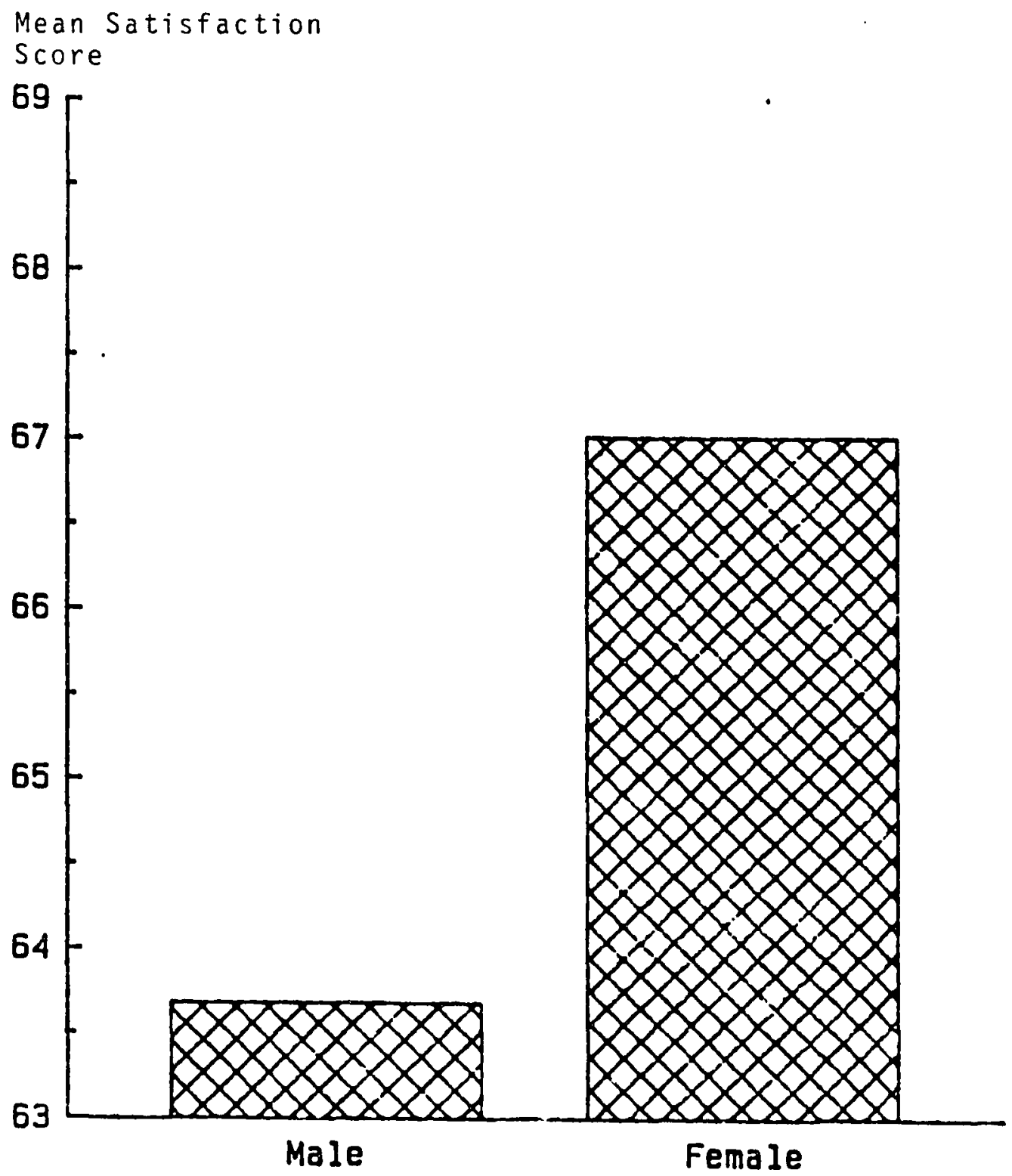

Figure 7. Level of satisfaction with teaching by gender. 
TABLE XXXVII

ANOVA FOR SATISFACTION WITH

TEACHING AND GENDER

\begin{tabular}{lrrr}
\hline SOURCE OF VARIATION & df & MS & $F$ \\
\hline Explained & 1 & 470.176 & $5.408^{*}$ \\
Residual & 169 & 86.938 & \\
\hline
\end{tabular}

$\star p<.03$

Relationship To Career. Based on the research that indicated there would be a relationship between the career stage, as distinguished by the individual's age, and the levels of job satisfaction, the scores for Satisfaction with Teaching were studied in relation to the independent variable Age arranged into three career stage groupings as outlined by Gould (1979):

1. Trial Stage $-22-30$ years

2. Stabilization Stage - 31-44 years

3. Maintenance Stage - 45-65 years

Hypothesis 1: Those teachers in the first three years of teaching will have a lower score on the subscale score Satisfaction with Teaching than teachers in other experiential levels.

Hypothesis 3: In the initial years of their careers, middle school teachers will have lowered scores on the subscale Satisfaction with Teaching (ages 22 to 30 years) followed by increased scores through the next 
career stage (ages 31 to 44 years), and, finally, lowered scores during the remaining years of their careers (ages 45 to 65 years).

Table XXXVIII and Figure 8 present the results of this analysis.

TABLE XXXVIII

THE LEVEL OF SATISFACTION

WITH TEACHING BY

THE AGE

\begin{tabular}{ccc} 
AGE & MEAN & $\begin{array}{c}\text { STANDARD } \\
\text { DEVIATION }\end{array}$ \\
\hline $22-30$ & 63.58 & 10.00 \\
$31-44$ & 66.84 & 8.86 \\
$45-65$ & 64.16 & 9.96 \\
\hline
\end{tabular}

As may be seen in Figure 8 , rather than following the classic pattern outlined by Gould (1975) and others, teachers in this sample appeared to follow more closely the pattern established by Greenfield and Blase (1980) in their study of secondary teachers in suburban New York communities. The first years of career involvement, the Trial State (Gould, 1979), are the lowest level of satisfaction among this sample of middle school teachers. This lower level is then followed by the Stabilization Stage (Gould, 1979) which has the highest level of satisfaction with teaching. Finaliy, the teachers moved into the Maintenance 


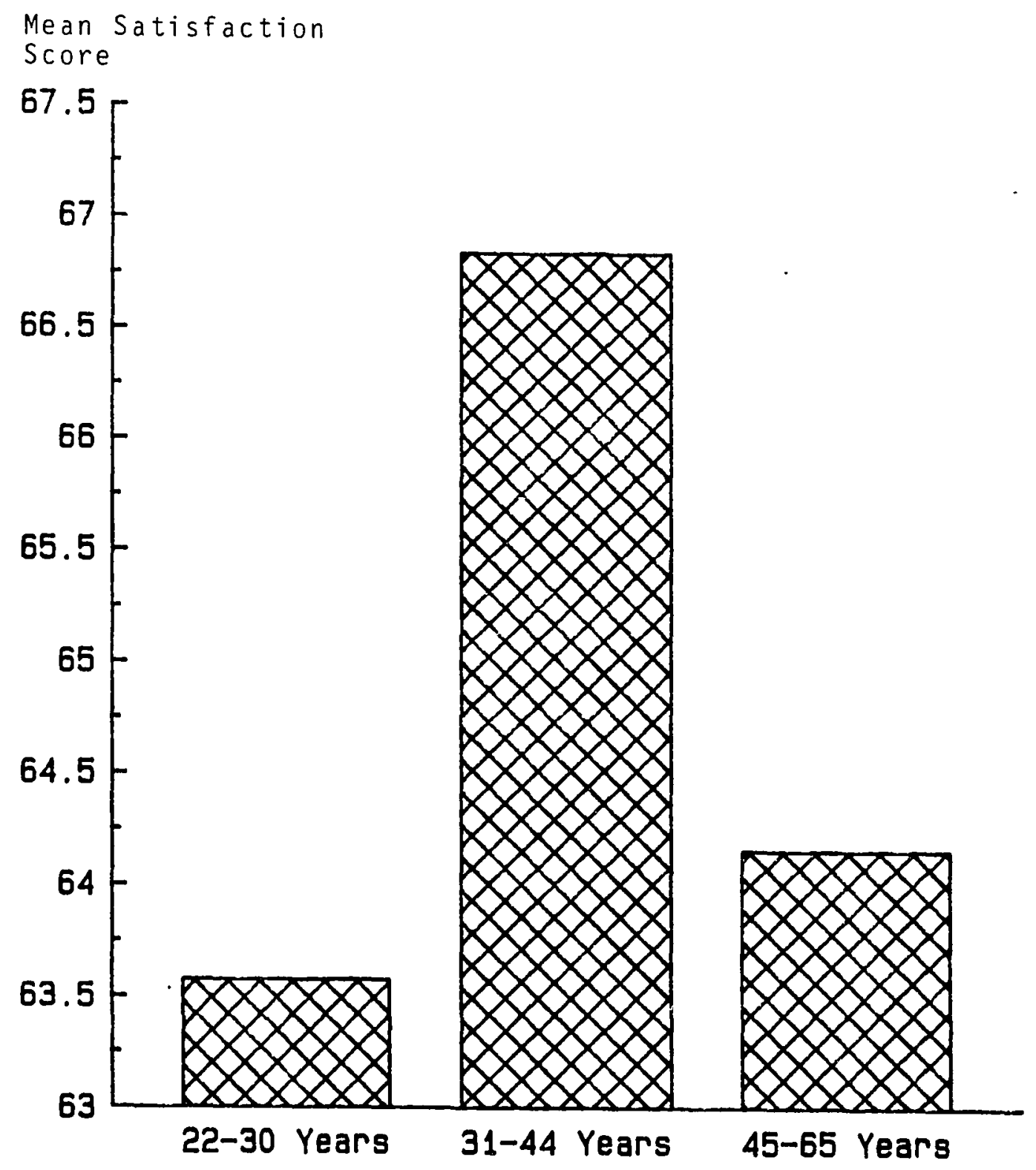

Figure 8 . Mean satisfaction with teaching by age of 
Stage (Gould, 1979) and manifested a lowered level of satisfaction but not as low as that exhibited in the Trial stage.

A univariate analysis of variance on the levels of Satisfaction with Teaching and an independent variable of each of the age groups indicated no significance in the relationship at any of the Career Stages. The pattern, however, described by Greenfield and Blase (1980) is repeated. Relationship To Years Taught. Pursuit of the pattern which Greenfield and Blase established is appropriate based on these results. In this pursuit, the same years of experience outlined by them in their work were looked at:

1 - 3 years experience

4 - 15 years experience

16 - highest years experience

It was found that this further analysis yielded support for the pattern established by Greenfield and Blase (1980), not only among the secondary teachers they studied, but among middle school teachers in this sample. Table XXXIX and Figure 9 further illustrate and summarize this relationship although, in the ANOVA procedures run on these data, no significant relationship was found. 
TABLE XXXIX

\section{LEVEL OF SATISFACTION WITH \\ TEACHING BY YEARS \\ TAUGHT}

\begin{tabular}{lll} 
YEARS TAUGHT & MEAN & STANDARD DEVIATION \\
\hline $1-3$ & 64.45 & 9.99 \\
$4-15$ & 66.14 & 9.38 \\
$16-$ high & 64.75 & 9.42 \\
\hline
\end{tabular}

Relationship to Certification. It was hypothesized as part of this study that elementary certified teachers would have higher scores on the Satisfaction with Teaching subscale than secondary teachers in the sample. This hypothesis was rejected. Although the mean for elementary teachers (66.08) in the sample is higher than that for secondary certified teachers (63.72), it was not significantly higher. Table XL summarizes the results of the scores for the subscale Satisfaction with Teaching for elementary and secondary certified teachers.

TABLE XL

LEVEL OF SATISFACTION

WITH TEACHING BY

CERT IF I CAT I ON

\begin{tabular}{lcc}
\hline CERTIFICAITON LEVEL & MEAN & STANDARD DEVIATION \\
\hline Elementary $(n=72)$ & 66.08 & 7.96 \\
Secondary $(n=60)$ & 63.72 & 10.82 \\
\hline
\end{tabular}




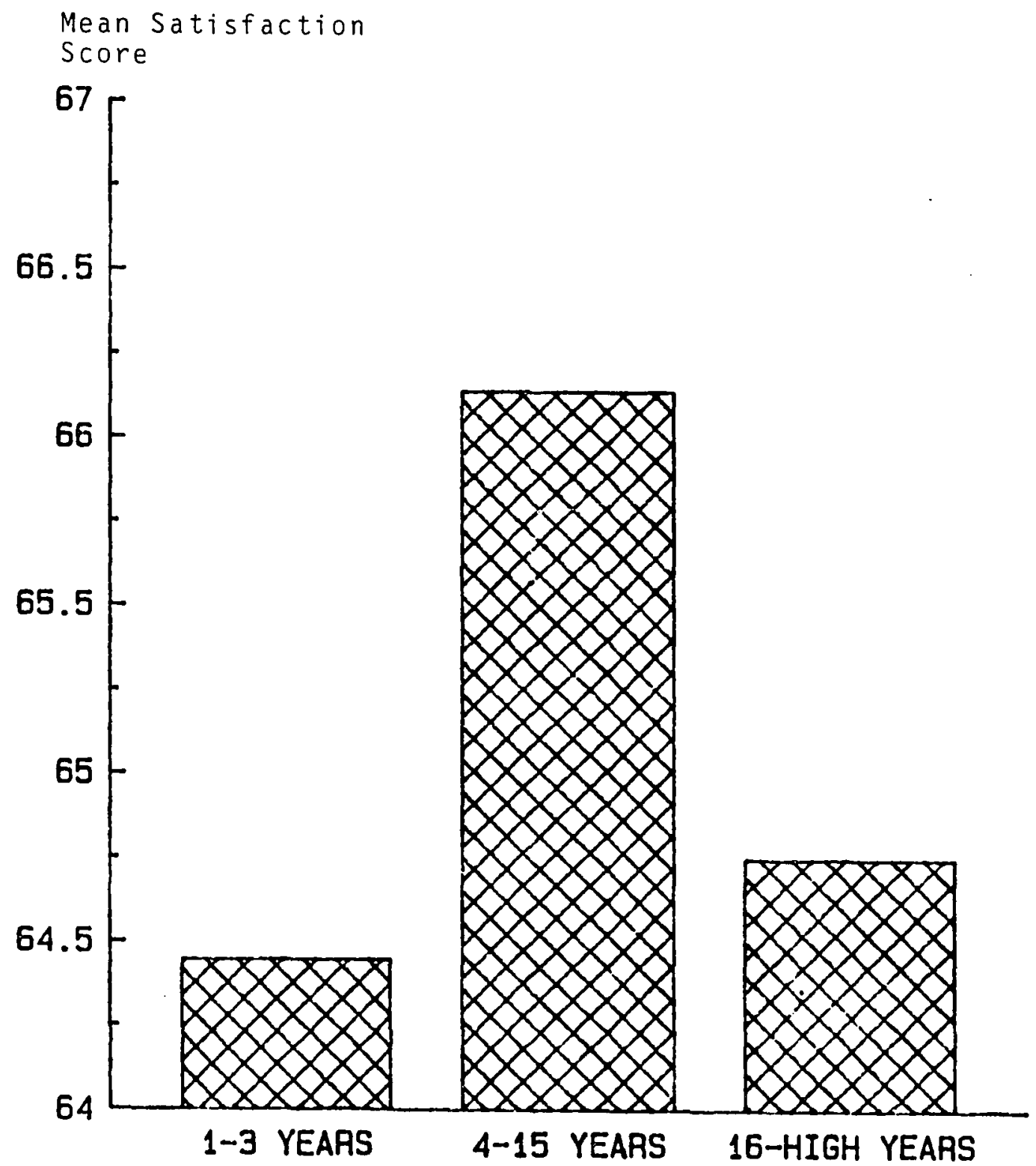

Figure 9. Mean satisfaction with teaching by years taught by respondents. 
Comparison To PTO Norms. The PTO norms for each subscale are provided as a means of comparing this sample to the populations that Bentley and Rempel (1980) have studied. Table XLI provides a summary of the relationship of this sample's scores to the 10th, 50th, and 90th percentiles of the norming sample. Figure 10 provides a look at the relationship of this sample's scores on each of the items to the 50 th percentile of the norming sample on each of the items. In all but six of the items, the middle school sample in this study scored below the 50 th percentile of the norming sample.

TABLE XLI

LEVEL OF SATISFACTION WITH TEACHING - MEDIANS

\begin{tabular}{ccccc}
\hline & \multicolumn{2}{c}{ NORM MEDIANS AT PERCENTILE } & \\
\cline { 2 - 5 } RESPONSE & 10 th & 50 th & 90 th & SAMPLE MEDIAN \\
\hline 19 & 3.3 & 3.7 & 3.8 & 3.571 \\
24 & 2.8 & 3.1 & 3.4 & 3.107 \\
26 & 3.2 & 3.6 & 3.8 & 3.571 \\
27 & 3.0 & 3.4 & 3.7 & 2.967 \\
29 & 2.4 & 2.9 & 3.2 & 2.649 \\
30 & 3.0 & 3.4 & 3.7 & 3.046 \\
46 & 3.3 & 3.7 & 3.8 & 3.609 \\
47 & 3.0 & 3.3 & 3.7 & 3.628 \\
50 & 3.3 & 3.6 & 3.8 & 3.827 \\
51 & 2.9 & 3.2 & 3.6 & 2.914 \\
56 & 3.7 & 3.8 & 3.9 & 3.852 \\
58 & 3.3 & 3.6 & 3.8 & 3.730 \\
60 & 3.2 & 3.6 & 3.8 & 3.055 \\
76 & 3.3 & 3.6 & 3.8 & 3.662 \\
78 & 3.2 & 3.5 & 3.8 & 3.590 \\
82 & 3.1 & 3.3 & 3.6 & 3.250 \\
83 & 2.9 & 3.2 & 3.6 & 3.180 \\
86 & 3.7 & 3.8 & 3.9 & 3.871 \\
89 & 3.5 & 3.7 & 3.9 & 3.708 \\
100 & 2.9 & 3.3 & 3.7 & 3.506 \\
\hline
\end{tabular}




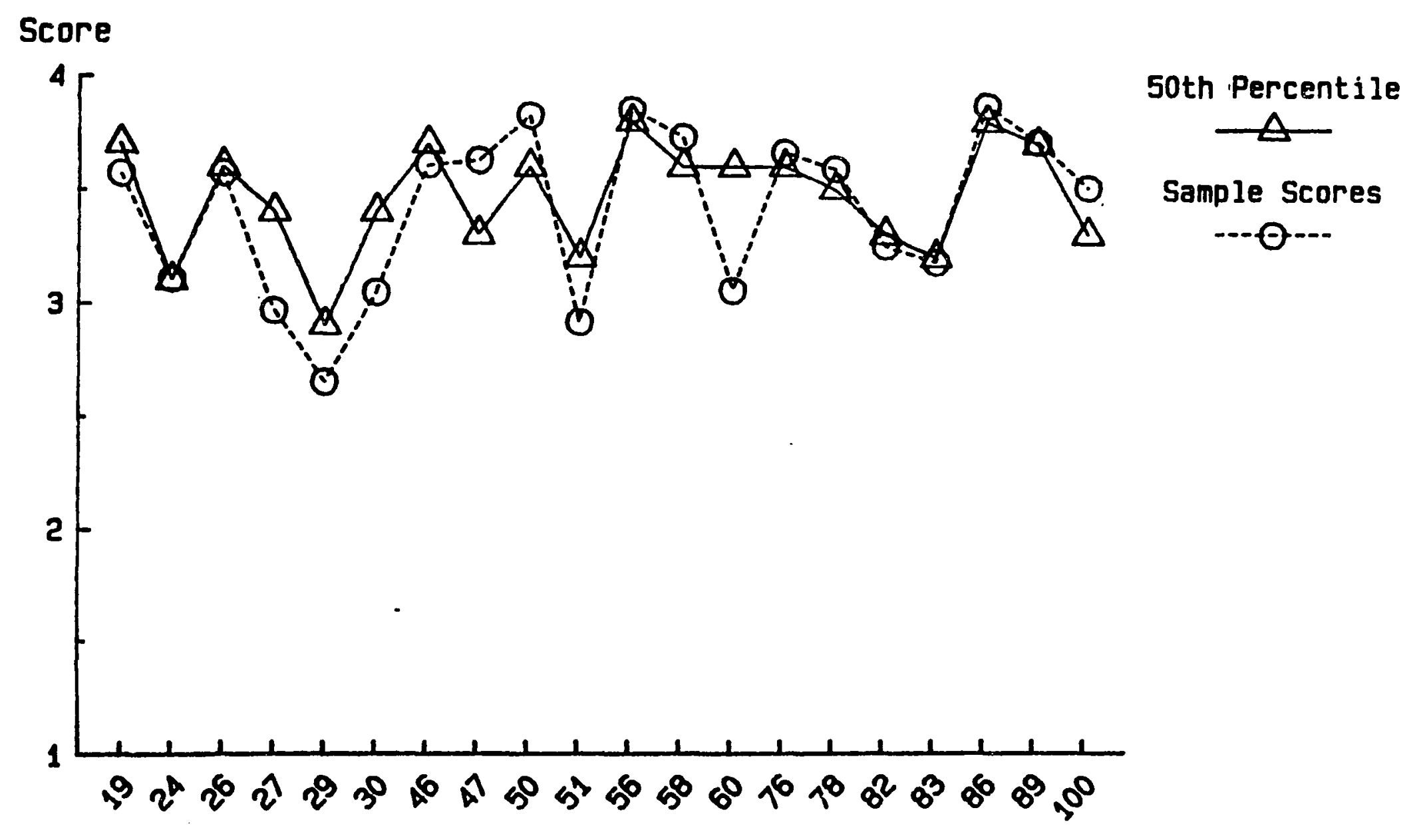

\section{Item Number}

Figure 10. Median satisfaction with teaching responses by item. 


\section{Rapport with the Principal}

Relationship to Gender

It was hypothesized that females would have higher subscale scores in Rapport related areas (i.e., Rapport with the Principal and Rapport Among Teachers). The results from this sample support that hypothesis. The mean score for females was 65.26 while that for males was 61.17 as illustrated by Figure 11. A summary of these results is found in Table XLII.

\section{TABLE XLII}

LEVEL OF RAPPORT WITH THE PRINCIPAL BY THE GENDER OF THE RESPONDENT

\begin{tabular}{llcc}
\hline GENDER & MEAN & STANDARD DEVIATION & $n$ \\
\hline Male & 61.17 & 12.80 & 78 \\
Female & 65.26 & 11.77 & 93 \\
\hline
\end{tabular}

The significance of this relationship was tested using univariate analysis of variance with gender as the independent variable and Rapport with the Principal as the dependent variable. It was found that the relationship was significant at the .05 level. Table XLIII presents the ANOVA for this relationship. 
TABLE XLIII

ANOVA OF THE SUBSCALE RAPPORT WITH

THE PRINCIPAL AND THE GENDER

OF THE RESPONDENT

\begin{tabular}{lccc}
\hline SOURCE & DF & MS & $F$ \\
\hline Between Groups & 1 & 710.1072 & $4.732 *$ \\
Within Groups & 169 & 150.0511 & \\
\hline${ }_{p}<.05$ & &
\end{tabular}

Relationship to Each School

It was further hypothesized (Hypothesis 2) that there would be a relationship of the scores on the subscale Rapport with the Principal and the managerial style of the individual principal. Specifically, the higher the task orientation of the principal, the lower the level of Rapport with the Principal. The mean scores for Rapport with the Principal in each of the schools (reported earlier) is summarized in Table XLIV. 


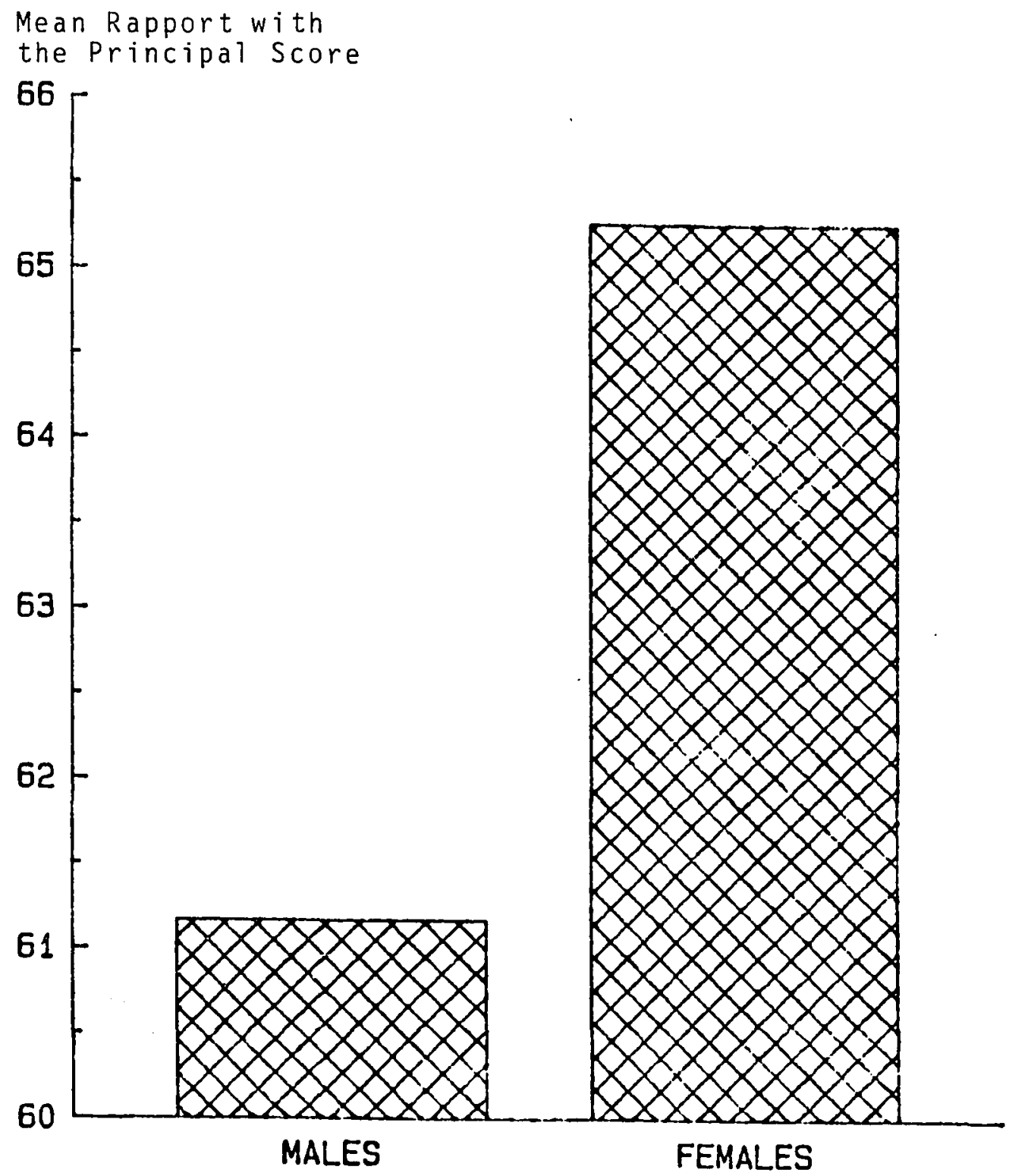

Figure 11. Mean rapport with the principal by gender of the respondent. 
TABLE XLIV

MEAN SCORES FOR RAPPORT WITH THE PRINCIPAL BY SCHOOL

\begin{tabular}{ccc}
\hline SCHOOL & MEAN & STANDARD DEVIATION \\
\hline 1 & 67.478 & 10.582 \\
2 & 59.826 & 12.890 \\
3 & 65.778 & 11.200 \\
4 & 65.391 & 11.273 \\
5 & 58.000 & 6.944 \\
6 & 70.357 & 8.082 \\
7 & 59.136 & 15.520 \\
8 & 64.947 & 9.449 \\
9 & 61.682 & 3.156 \\
\hline
\end{tabular}

Based on the differences observed in the means, an ANOVA was computed which yielded a significance at the .05 level. Table XLV presents this analysis.

TABLE XLV

ANOVA OF THE SUBSCALE RAPPORT WITH

PRINCIPAL WITH THE SCHOOL OF

THE RESPONDENT

\begin{tabular}{lrrr}
\hline SOURCE & df & MS & F \\
\hline Between Groups & 8 & 296.7890 & $2.029 *$ \\
Within Groups & 162 & 146.2620 & \\
\hline
\end{tabular}

$\star p<.05$ 
Further analysis of the hypothesis that there would be a relationship between Rapport with the Principal and managerial style, necessitates looking at the self-perceived management styles of the principals of each of the buildings.

In School 1 the principal indicates possession of a bias that the teaching/learning process is the most important process that occurs in the school. The principal's role is that of managing resources and time to the best of his/her ability. Staff meetings should be held only when they are absolutely necessary (a maximum of once every other week) and every effort should be made to lessen the paperwork demands that are placed on the teachers. There is a need to be open to teachers and to stay in contact with the demands on them by teaching a class a day. It is essential to relate individually to the teachers and understand the demands on time.

In School 2 the principal perceives him/herself as democratic but is able and comfortable with using whatever is necessary to get the job done. The principal is confused by labeling a management style but tries to be humanistic while maintaining realism. At times this principal feels that it is necessary to face conflict. It is essential to be pragmatic about the management approach, and, if it works, it's good. 
In School 3 the principal indicates a belief in participatory leadership and feels that this group of teachers is perfect match for this belief because someone is always picking up on projects, discussing philosophy, and helping each other. This principal feels that the manager must "look for a match" between managerial style and the staff. The style that this principal has chosen will not, according to the principal, work in all schools. Without a match, it could be a failure.

In School 4 the principal tries to listen to all interested teachers but reserves the right to make any decision. There is very little voting in this school but there is a lot of talking. In the end; however, it is the principal that makes the decision. Historically, the present principal indicates that this particular building started out as a collective decision-making management style building when it was under the prior principal. There was chaos as a result of this according to the present principal, and he/she perceives that he/she was brought in to "straighten out" the mess. This principal is most comfortable with this style of management and feels that this is the most effective evaluation tool for the success of a managerial style.

In School 5 the principal believes in participatory management but reserves the right of final decision ("I make the final decision"). "I think issues that affect the staff need to have their input and they ought to have a part." 
This principal sees a danger in this input process because it can be misunderstood by the staff, and there is the "inevitable" member of the staff who feels that he/she was not listened to during the discussion. This principal sets priorities such as academic learning time, discusses the problems with the leadership team in the school, and uses this team as a support group when processing through problem solving situations. The problem is then discussed with the staff in general, but the priority that was set is not forgotten, and the final decision is made with that priority in mind. Understanding the teachers as individuals is important to the style of this administrator. The principal feels that if the teachers perceive that they and their viewpoints are understood, they are more likely to buy into the decision and have ownership.

In School 6 the principal sets priorities that determine the style of leadership that is practiced. This means that as a building principal, this individual has chosen "kids as a number one priority." Parents and the staff of the school are of lower priority. With this as a backdrop for all decision-making, this principal gathers all the data it is possible to collect including the input of all of the staff members. Consensus is desired, but, if that cannot be achieved, an effort is made to modify the decision to solve the problems creating dissension. During all of this the 
priority structure is kept in mind. This principal also indicates a real effort is made to avoid conflict.

School 7 has a principal who perceives him/herself as a leader not a dictator. The thrust is to work with, not through, people that are teachers in the building with the goals of achieving desired tasks. As a manager, this principal indicates that tasks are delegated based on strength and interest level of the individual employees. Decisionmaking is said to be based on effective individual involvement in the process before the decision is made. The style is based on a belief in the ability of all the teachers to complete the task that must be completed. The principal describes this style as "benevolent." This principal believes that it is those you work with that either make or break you.

In School 8, the principal believes that the key is to be "the walking type." That is, the principal should be accessible to the teachers and should not hide in the office. When decisions are made they should involve people who are affected by the decisions. The principal must let these people know that their opinion is valued and must be concerned about them as individuals. Although it is, according to this principal, necessary for the decision to finally be made by the principal, it is necessary to let people know why a decision is being made, and it is important to let teachers know that they are respected and that you know that 
what they are doing is imporiant. He/she feels that allowing them to participate in decision-making indicates these things to teachers. The principal must, according to this individual, provide support to teachers so they have the ability and want to improve the quality of education for the students in the school. It is best to employ risk takers to make a creative atmosphere in the building. As a building leader, the principal must know how to let the teachers try new things "not stay in that square box."

The principal in School 9 indicated a management style that is flexible. This principal indicated that ". . the most unequal treatment is to treat people equally." He/she makes no attempt to be consistent in the treatment of all the teachers. The bottom line is to get the job done - not just to do the job because one feels compelled to do it but to buy into the need for the job to be done. "I operate based on principles that I believe in strongly. I am student and teacher based." This principal has a sense that there are people who want power and advancement but are not aware that the principal's job is not the place to get that. Summary. It is possible to use this mixture of data to provide a picture of the relationship of the levels of Rapport with the Principal as provided by the subscale scores and the self reported administrative style of the principals in the sample schools. This will provide a picture to assist in clarifying the data in relationship to 
Hypothesis 6: The levels of job satisfaction, as determined by the scores on the PTO, will be lower in buildings where the principal has indicated a higher task orientation and less relationship orientation in his/her self-perceived management style analysis. The results are somewhat mixed; however, the lowest Rapport score was matched to a principal who was highly relationship oriented (School 7 ). On the other hand, the highest mean score was from a school where the administrator combines Task and Relationship orientations (School 6). A brief summary of these comparisons is provided by Table XLVI.

\section{Relationship to Age}

ANOVA's were used to determine if there was any relationship between the various age groupings noted under satisfaction with Teaching including Career Stages and Number of Years Taught. None of these yielded a significant relationship, however, except for those individuals in what Gould (1979) termed the Maintenance Stage (45-65). At this Career Stage individual Rapport with the Principal was statistically significant. Table XLVII presents the Scheffé test results of this analysis. 
TABLE XLVI

MANAGEMENT STYLE AND MEAN RAPPORT

WITH PRINCIPAL SCORE

\begin{tabular}{|c|c|c|}
\hline SCHOOL & PRINCIPAL'S STYLE & $\begin{array}{l}\text { SCORE ON RAPPORT } \\
\text { WITH PRINCIPAL }\end{array}$ \\
\hline 1 & $\underbrace{\text { Task }}_{\text {time }}$ - Manage resources and & 67.478 \\
\hline 2 & $\begin{array}{l}\text { Task-Relationship - Democratic } \\
\text { but do what is necessary to } \\
\text { get the job done }\end{array}$ & 59.826 \\
\hline 3 & Relationship - Participatory & 65.778 \\
\hline 4 & $\begin{array}{l}\frac{\text { Task-Relationship }}{\text { all but makes the final }} \\
\text { decision }\end{array}$ & 65.391 \\
\hline 5 & 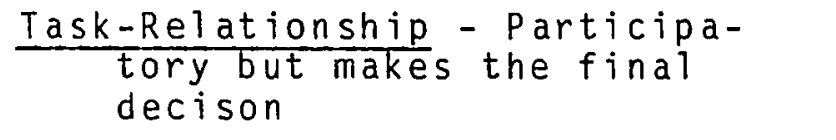 & 58.000 \\
\hline 6 & \multicolumn{2}{|l|}{$\frac{\text { Task-Relationship }}{\text { and teachers are prids, parents, }}$} \\
\hline \multirow[t]{2}{*}{7} & $\begin{array}{l}\text { (in that order) } \\
\frac{\text { Relationship - Leader not a }}{\text { dictator, a "benevolent" }}\end{array}$ & 70.357 \\
\hline & manager & 59.136 \\
\hline 8 & $\begin{array}{l}\frac{\text { Task-Relationship - "Walking }}{\text { type" involve people but }} \\
\text { the decision is finally made } \\
\text { by the principal }\end{array}$ & 64.947 \\
\hline 9 & $\begin{array}{l}\text { Task - Flexible, but no attempt is } \\
\text { made to be consistent in the } \\
\text { treatment of teachers - the } \\
\text { bottom line is to get the job } \\
\text { done }\end{array}$ & 61.682 \\
\hline
\end{tabular}


TABLE XLVII

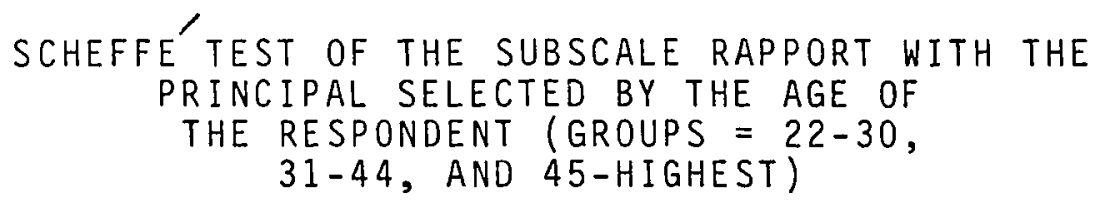

\begin{tabular}{lrrr}
\hline GROUP $=45-65$ & & MS & $F$ \\
SOURCE & $d f$ & 379.0599 & $2.153^{*}$ \\
\hline Between Groups & 8 & 176.0532 & \\
Within Groups & 47 & & \\
\hline
\end{tabular}

$\star_{p}<.05$

Comparison to PTO Norms. The norming sample comparison is again provided to the reader to allow a study of this sample against the norms established by Bentley and Rempel (1980). Unlike the relationship of Satisfaction with Teaching, the medians of the sample for Rapport with the Principal are almost consistently above the 50 th percentile. This analysis is illustrated in Table XLVIII and Figure 12 . 
TABLE XLVIII

RAPPORT WITH PRINCIPAL

\begin{tabular}{|c|c|c|c|c|}
\hline \multirow[b]{2}{*}{ RESPONSE } & \multicolumn{3}{|c|}{ NORM MEDIANS BY PERCENTILES } & \multirow[b]{2}{*}{ SAMPLE MEDIAN } \\
\hline & 10 th & 50 th & $90 \mathrm{th}$ & \\
\hline 2 & 2.5 & 3.2 & 3.7 & 3.476 \\
\hline 3 & 2.0 & 3.0 & 3.6 & 2.792 \\
\hline 5 & 2.3 & 3.2 & 3.7 & 3.219 \\
\hline 7 & 2.2 & 3.1 & 3.7 & 3.473 \\
\hline 12 & 1.4 & 2.6 & 3.1 & 3.038 \\
\hline 23 & 2.3 & 3.0 & 3.5 & 3.352 \\
\hline 38 & 2.9 & 3.4 & 3.8 & 3.619 \\
\hline 41 & 1.9 & 2.8 & 3.6 & 3.254 \\
\hline 43 & 2.4 & 3.0 & 3.5 & 3.277 \\
\hline 44 & 2.1 & 3.0 & 3.6 & 3.194 \\
\hline 61 & 2.2 & 3.0 & 3.6 & 3.160 \\
\hline 62 & 2.4 & 3.4 & 3.7 & 3.517 \\
\hline 69 & 2.7 & 3.2 & 3.7 & 3.414 \\
\hline 70 & 2.8 & 3.5 & 3.8 & 3.686 \\
\hline 72 & 1.9 & 2.8 & 3.5 & 3.063 \\
\hline 74 & 2.9 & 3.4 & 3.7 & 3.686 \\
\hline 92 & 3.0 & 3.4 & 3.8 & 3.693 \\
\hline 93 & 2.5 & 3.0 & 3.5 & 3.331 \\
\hline 95 & 2.4 & 3.2 & 3.7 & 3.299 \\
\hline
\end{tabular}




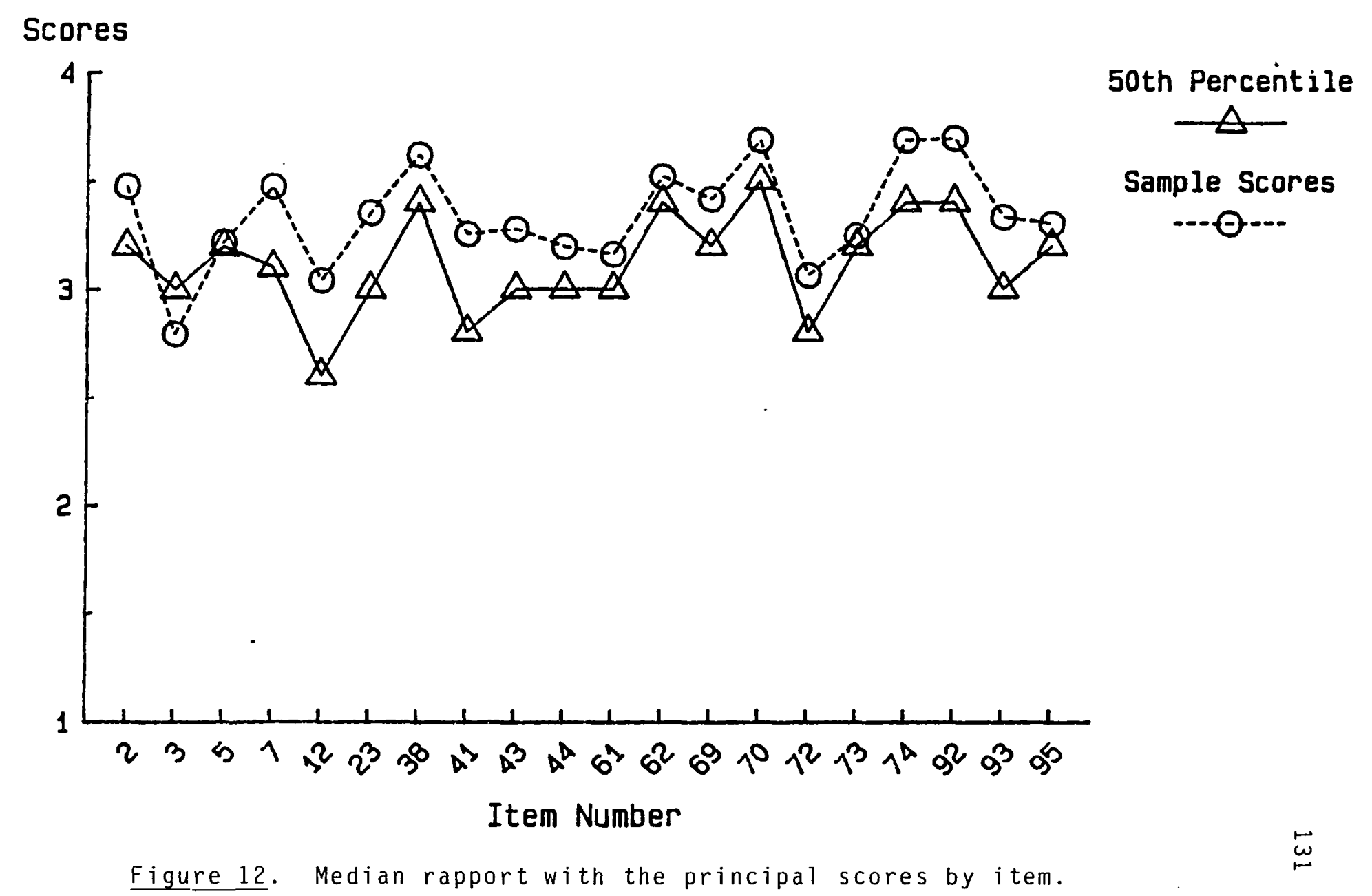




\section{Rapport Among Teachers}

\section{Relationship with Gender}

It was hypothesized that, like Rapport with the Principal, there would be a relationship between the gender of the respondents and the level of Rapport Among Teachers. Specifically, the hypothesis called for females to have higher mean scores than males on this subscale. It was found, however, that there was no significant relationship between the gender of the respondents and the score on this subscale.

Relationship to District of the Respondent

The only significant relationships of this subscale to biographical information pertaining to the respondents had to do with the locale of the teacher by district and by school. In the case of district location there was a significant relationship found using univariate analysis of variance and subsequent use of the scheffé test. Table XLIX presents these findings. 
TABLE XLIX

ANOVA OF THE SUBSCALE RAPPORT AMONG TEACHERS

WITH THE DISTRICT OF THE RESPONDENT

\begin{tabular}{lrrr}
\hline SOURCE & df & \multicolumn{1}{c}{ MS } & F \\
\hline Between Groups & 3 & 237.2885 & $7.243^{*}$ \\
Within Groups & 167 & 32.7627 & \\
\hline
\end{tabular}

$\star_{p}<.001$

Relationship to School of the Respondent

As with the relationship of Rapport Among Teachers

with District there is a statistically significant relationship between the school of the respondents and the levels of Rapport Among Teachers as represented by the scores on the subscale of the PTO. The results of the univariate analysis of variance using the Scheffé test are presented in Table L.

TABLE L

ANOVA OF THE SUBSCALE RAPPORT AMONG TEACHERS

WITH THE SCHOOL OF THE RESPONDENT

\begin{tabular}{lrrr}
\hline SOURCE & $\mathrm{df}$ & $\mathrm{MS}$ & $\mathrm{F}$ \\
\hline Between Groups & 8 & 148.9203 & $4.833^{*}$ \\
Within Groups & 162 & 30.8140 & \\
\hline
\end{tabular}

$\star_{p}<.001$

Comparison to PTO Norms

On this subscale all of the items are above the 50 th percentile of the norming sample. Table LI and Figure 13 present this data. 


\section{Scores}

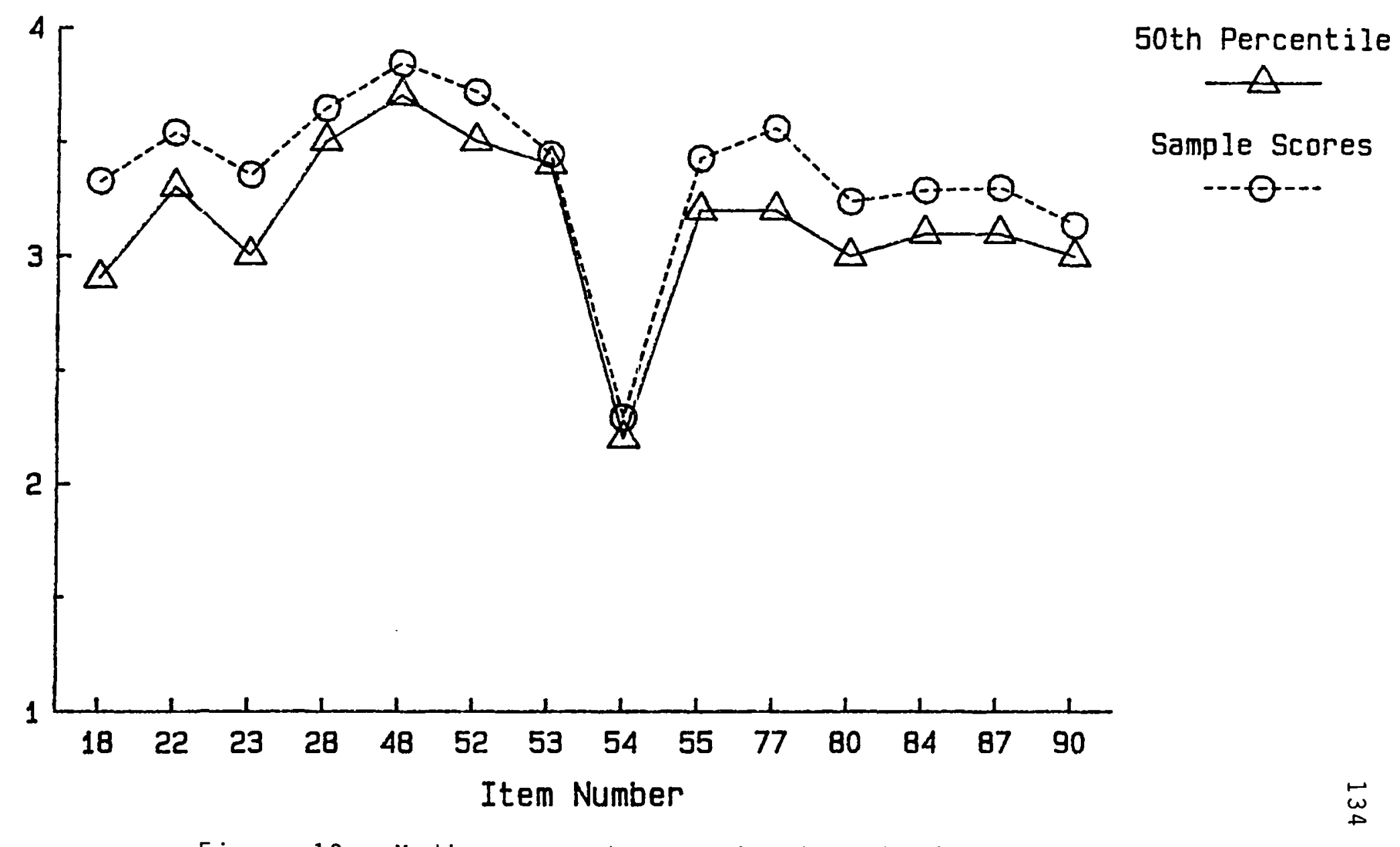

Figure 13. Median rapport among teachers by item. 
TABLE LI

RAPPORT AMONG TEACHERS

\begin{tabular}{|c|c|c|c|c|}
\hline RESPONSE & $\frac{\text { NORM }}{10 t h}$ & $\frac{\text { MEDIANS FOR }}{50 \mathrm{th}}$ & $\frac{\text { PERCENTILES }}{90 t h}$ & SAMPLE MEDIAN \\
\hline $\begin{array}{l}18 \\
22 \\
23 \\
28 \\
48 \\
52 \\
53 \\
54 \\
55 \\
77 \\
80 \\
84 \\
87 \\
90\end{array}$ & $\begin{array}{l}2.0 \\
3.0 \\
2.5 \\
3.1 \\
3.4 \\
3.0 \\
3.1 \\
1.5 \\
2.8 \\
2.8 \\
2.8 \\
2.9 \\
2.8 \\
2.7\end{array}$ & $\begin{array}{l}2.9 \\
3.3 \\
3.0 \\
3.5 \\
3.7 \\
3.5 \\
3.4 \\
2.2 \\
3.2 \\
3.2 \\
3.0 \\
3.1 \\
3.1 \\
3.0\end{array}$ & $\begin{array}{l}3.6 \\
3.7 \\
3.5 \\
3.8 \\
3.9 \\
3.9 \\
3.7 \\
2.9 \\
3.6 \\
3.7 \\
3.3 \\
3.4 \\
3.5 \\
3.3\end{array}$ & $\begin{array}{l}3.326 \\
3.539 \\
3.352 \\
3.645 \\
3.842 \\
3.716 \\
3.444 \\
2.292 \\
3.428 \\
3.560 \\
3.239 \\
3.290 \\
3.301 \\
3.137\end{array}$ \\
\hline
\end{tabular}

Relationship to Teacher Status Subscale

\section{Certification}

The literature would lead to the conclusion that middle school teachers should have lowered status due to their lack of recognition among state institutions and their peers in the teaching profession (McEwin, 1983). The results of this study when comparing the norming sample to the teachers in the present sample tends to support this conclusion. With one exception, the item medians of the sample are below the 50 th percentile of the norming sample of Bentley and Rempel (1980). These results are presented in Table LII and Figure 14 . 


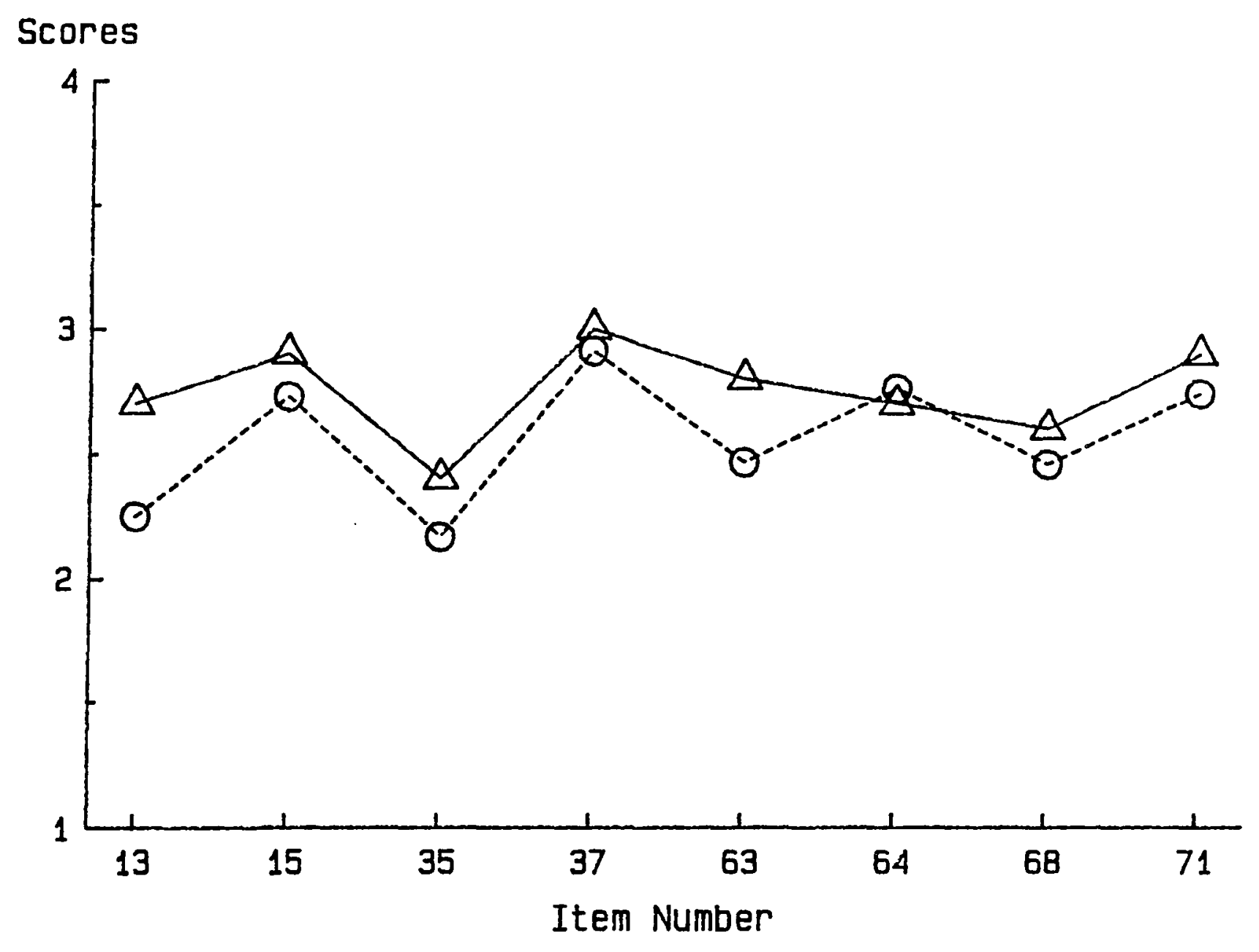

50th Percentile

$\Delta$

Sample Scores

---ध-..

Figure 14. Median teacher status scores by item. 
TABLE LII

TEACHER STATUS

\begin{tabular}{ccccc}
\hline RESPONSE & \multicolumn{2}{c}{ NORM } & MEDIANS BY PERCENTILE & SAMPLE MEDIAN \\
\hline $10 t h$ & $\frac{50 t h}{n}$ & $\frac{9 t h}{n}$ & 171 \\
\hline 15 & 2.1 & 2.7 & 3.2 & 2.250 \\
35 & 2.5 & 2.9 & 3.4 & 2.729 \\
37 & 1.7 & 2.4 & 2.9 & 2.169 \\
63 & 2.7 & 3.0 & 3.4 & 2.913 \\
64 & 2.5 & 2.8 & 3.3 & 2.467 \\
68 & 2.0 & 2.7 & 3.1 & 2.762 \\
71 & 2.0 & 2.6 & 3.2 & 2.459 \\
\hline
\end{tabular}

Morale

The total score of the PTO provides a measurement for Morale of the respondents. This score is related to the biographical characteristics of the respondents in the sample.

\section{Gender}

The gender of the respondent in each district and school indicates a relationship that is significant between being female and having higher levels of Morale as determined by the PTO.

For the total sample the mean Morale score for males was 303.54 while the mean score for females was 312.42 with 
standard deviations of 33.23 and 37.25 respectively. This indicates that the higher levels of morale for females may be a continuation from Satisfaction with Teaching and Rapport with the Principal. These findings are presented in Table LIII.

TABLE LII I

TOTAL PTO SCALE SCORES FOR MORALE BY GENDER

\begin{tabular}{lcc}
\hline GENDER & MEAN & STANDARD DEVIATION \\
\hline Male & 303.54 & 33.23 \\
Female & 312.42 & 37.25 \\
\hline
\end{tabular}

In addition, as mentioned above, there is a continued relationship into the district and school level which is statistically significant and indicates that females are higher on the score which measures the morale of the respondents. ANOVAs are presented in Tables LIV through LVI to illustrate the strength of this relationship.

TABLE LIV

ANOVA FOR MORALE AND GENDER OF RESPONDENT BY SCHOOL

\begin{tabular}{lccc}
\hline DEPENDENT & MORALE & MS & F \\
INDEPENDENT & DF & 1148.417 & 1.045 \\
\hline Males by School & 8 & 3205.516 & $2.640^{*}$ \\
\hline Females by School & 8 & 8 & \\
\hline
\end{tabular}

$\star p<.02$ 
TABLE LV

MORALE BY DISTRICT

\begin{tabular}{cccc}
\hline DISTRICT & MEAN & STANDARD DEVIATION & $n$ \\
\hline 1 & 308.51 & 33.90 & 41 \\
2 & 315.96 & 37.34 & 46 \\
3 & 298.35 & 37.63 & 51 \\
4 & 313.09 & 29.58 & 33 \\
\hline
\end{tabular}

TABLE LVI

ANOVA FOR MORALE AND GENDER OF RESPONDENT BY DISTRICT

\begin{tabular}{llll}
\hline $\begin{array}{l}\text { DEPENDENT I } \\
\text { INDEPENDENT }\end{array}$ & $\begin{array}{l}\text { MORALE } \\
\text { DF }\end{array}$ & MS & F \\
\hline $\begin{array}{l}\text { Main Effects of } \\
\text { District for Males }\end{array}$ & 3 & 1582.618 & 1.458 \\
$\begin{array}{l}\text { Main Effects of } \\
\text { District for Females }\end{array}$ & 3 & 7088.555 & $5.931 *$ \\
\hline
\end{tabular}

$\star_{p}<.002$

$\underline{\text { Age }}$

Only one significant relationship between Morale and the age of the respondent was found to exist. Using Gould's Career Stages (1979), the same univariate analyses of variance followed by the Scheffé test were applied and a significant relationship was found between the Maintenance Stage (45-65 years) and the Morale of the respondents. The mean Morale score for this age group was 309.46 with a standard 
deviation of 39.98. A presentation of the results of this analysis is provided in Tables LVII through LIX.

\section{TABLE LVII}

MEAN MORALE SCORES FOR GOULD'S

CAREER STAGES (1979)

\begin{tabular}{lcc}
\hline CAREER STAGE & MEAN & STANDARD DEVIATION \\
\hline Trial Stage $(21-30)$ & 304.54 & 33.11 \\
Stabilization Stage $(31-44)$ & 308.70 & 33.74 \\
Maintenance Stage $(45-65)$ & 309.46 & 39.98 \\
\hline
\end{tabular}

TABLE LVII I

ANOVA OF MORALE SCALE WITH THE

DISTRICT OF THE RESPONDENT

$A G E=(45-65)$

\begin{tabular}{lccc} 
SOURCE & df & MS & F \\
\hline Between Groups & 3 & 4054.3328 & $2.783^{*}$ \\
Within Groups & 52 & 1457.0562 & \\
\hline
\end{tabular}

$\star p=.05$

TABLE LVIX

ANOVA OF MORALE SCALE WITH THE

SCHOOL OF THE RESPONDENTS

\begin{tabular}{lrrr}
\hline SOURCE & $\mathrm{df}$ & MS & $\mathrm{F}$ \\
\hline Explained & 8 & 1905.260 & $1.537^{\star}$ \\
Residual & 162 & 1239.455 & \\
\hline
\end{tabular}

$\star p>.05$ 


\section{Administrators' Questionnaire}

\section{Further Findings of the Administrators' Questionnaire}

Funding Problems in the Districts. Only one of the districts was reported by the principals questioned to have no funding problems of any proportion over the last five years. The remaining districts (1,2, and 3) were reported to have significant problems including levy failures, the impact of decreased state funding which is not being offset by local funding, and lack of a tax base to support the school district. In the case of District 2 , the funding problems have resulted in the loss of staffing at the school and district levels.

\section{Labor Relations Problems. District 1 and District 3} were reported to have labor problems within the past five years. In the case of District 3 these problems culminated in a strike, while District 1 was able to avert the strike just prior ("We came within three minutes of striking") to its occurrence.

Middle School Characteristics. Frincipals were asked to rate each of their schools on the level of implementation that presently existed for each of the following characteristics:

1. Continuous progress, non-graded organization that allows students to progress at their own individual rate regardless of chronological age; 
2. Multi-material or multi-media approach to instruction;

3. Flexible schedules;

4. Social experiences that are appropriate to the tranescent youth;

5. Physical and intramural activities based solely on the needs of students;

6. Team teaching;

7. Planned gradualism to ease the transition from childhood dependence to adult independence;

8. Exploratory and enrichment studies;

9. Guidance services (including an advisee/advisor program) ;

10. Independent study available to students;

11. Basic skills repair and extension;

12. Creative experiences;

13. A security factor that meets the students' needs for a security group;

14. Student evaluation that is personal, positive, nonthreatening, and individualized;

15. A community relations program that is two-way;

16. A broad spectrum of student services;

17. Auxiliary staffing to provide individual help to students;

18. Effective communication within grade level;

19. Effective communication across grade levels; and 
20. Effective communication across disciplines.

Tables LX and LXI summarize the results of that portion of the administrators' questionnaire. The highest mean score for the schools was 8.3 while the lowest was 4.65 . The maximum rating given was 10 , and it occurred only once. The lowest rating was 0 and it, too, occurred only once.

TABLE LX

RANKINGS BY PRINCIPALS OF MIDDLE

SCHOOL CHARACTERISTICS

\begin{tabular}{|c|c|c|c|c|c|c|c|c|c|c|}
\hline \multirow[b]{2}{*}{ CHARACTERISTIC } & \multicolumn{9}{|c|}{ SCHOOL } & \multirow[b]{2}{*}{ MEAN } \\
\hline & $\overline{1}$ & 2 & 3 & $\overline{4}$ & 5 & 6 & 7 & 8 & $\overline{9}$ & \\
\hline $\begin{array}{l}\text { Cont Progress } \\
\text { Multi-Media } \\
\text { Flexible Schedule } \\
\text { Approp Soc Exp } \\
\text { Approp Phys Exp } \\
\text { Team Teaching } \\
\text { PlannedGradual } \\
\text { Explor/Exrich } \\
\text { Guidance Serv } \\
\text { Indep Study } \\
\text { Basic Skills } \\
\text { Creative Exper } \\
\text { Security Factor } \\
\text { Evaluation } \\
\text { Commun Relat } \\
\text { Student Serv } \\
\text { Aux Staff } \\
\text { Comm w/in Grades } \\
\text { Comm bet Grades } \\
\text { Comm w/in Discip }\end{array}$ & $\begin{array}{l}3 \\
2 \\
1 \\
3 \\
5 \\
2 \\
5 \\
5 \\
8 \\
7 \\
7 \\
7 \\
7 \\
4 \\
8 \\
7 \\
4 \\
8 \\
6 \\
5\end{array}$ & $\begin{array}{r}6 \\
9 \\
6 \\
9 \\
10 \\
7 \\
9 \\
10 \\
9 \\
9 \\
8 \\
9 \\
9 \\
8 \\
8 \\
8 \\
5 \\
9 \\
9 \\
9\end{array}$ & $\begin{array}{l}2 \\
6 \\
2 \\
8 \\
6 \\
2 \\
9 \\
5 \\
9 \\
2 \\
8 \\
6 \\
6 \\
5 \\
5 \\
9 \\
7 \\
6 \\
8 \\
7\end{array}$ & $\begin{array}{l}4 \\
2 \\
2 \\
6 \\
8 \\
5 \\
3 \\
6 \\
2 \\
4 \\
8 \\
5 \\
5 \\
4 \\
6 \\
6 \\
2 \\
5 \\
5 \\
5\end{array}$ & $\begin{array}{l}5 \\
7 \\
0 \\
6 \\
6 \\
4 \\
7 \\
5 \\
7 \\
5 \\
7 \\
6 \\
7 \\
8 \\
5 \\
6 \\
2 \\
4 \\
4 \\
5\end{array}$ & $\begin{array}{c}3 \\
5.5 \\
6 \\
7 \\
6 \\
2 \\
6 \\
7 \\
5 \\
5 \\
6 \\
6 \\
8 \\
3 \\
7 \\
6 \\
4 \\
6 \\
5 \\
6\end{array}$ & $\begin{array}{l}5 \\
5 \\
4 \\
6 \\
7 \\
7 \\
5 \\
7 \\
6 \\
7 \\
8 \\
6 \\
6 \\
7 \\
5 \\
8 \\
6 \\
6 \\
5 \\
5\end{array}$ & $\begin{array}{l}3 \\
7 \\
2 \\
6 \\
6 \\
5 \\
5 \\
4 \\
2 \\
3 \\
7 \\
6 \\
5 \\
5 \\
5 \\
8 \\
2 \\
6 \\
6 \\
5\end{array}$ & $\begin{array}{l}4 \\
7 \\
4 \\
8 \\
7 \\
7 \\
4 \\
8 \\
7 \\
7 \\
7 \\
7 \\
4 \\
7 \\
7 \\
8 \\
7 \\
7 \\
7 \\
7\end{array}$ & $\begin{array}{l}3.89 \\
5.61 \\
3.00 \\
6.56 \\
6.78 \\
4.56 \\
5.89 \\
6.33 \\
6.11 \\
5.44 \\
7.33 \\
6.44 \\
6.33 \\
5.67 \\
6.22 \\
7.33 \\
4.33 \\
6.33 \\
6.11 \\
7.11\end{array}$ \\
\hline
\end{tabular}


TABLE XLI

MEAN LEVELS OF SCHOOL IMPLEMENTATION OF

MIDDLE SCHOOL CHARACTERISTICS

\begin{tabular}{ll}
\hline SCHOOL & MEAN \\
\hline 1 & 5.20 \\
2 & 8.30 \\
3 & 5.90 \\
4 & 4.65 \\
5 & 5.30 \\
6 & 5.48 \\
7 & 6.05 \\
8 & 4.90 \\
9 & 6.55 \\
\hline
\end{tabular}

Summary. With the exception of school 2 the schools in this sample have means indicating implementation levels below the 75 percent level for the characteristics that are associated with the middle school. These results are consistent with the findings of Riegle (1971), Bohlinger (1981), and Beckman (1981).

Further Information from Administrator's Questionnaire and Anecdotes. In District 3 there was considerable concern with the fact that there had been a strike within the last five years. Both administrators and teachers commented on the difficulties that still existed due to this and the split in staff caused by the refusal of some staff members 
to go out on strike. One of the principals indicated that the strike ". . had a dramatic impact." Although this principal indicated that $90 \%$ of the people involved were over it in the first six months, there were still people on the staff who ". . had vendettas." In the other school in District 3 the principal only alluded to any difficulties, but one teacher approached the researcher to state that the feelings were still very high against the administration and that he would not turn his questionnaire into the office but would mail it.

Summary

In this study, nine schools from four suburban school districts were sampled with 171 respondent questionnaires being found to be usable. The data collected from these questionnaires provided direction on the hypotheses that were presented in Chapter I. Areas of interest that were addressed for analysis included the scores on the subscales of the PTO: Satisfaction with Teaching, Rapport with the Principal, Rapport Among Teachers, and the total score from the PTO that represented Morale for the Teachers.

In addition to addressing the sample as a whole, the data was analyzed by district and school to determine any results that might have been outlying and creating misleading results in the total sample. 
Based upon this data it is possible to draw some conclusions about the sample of middle school teachers that were studied. 


\section{CHAPTER V}

SUMMARY, CONCLUSIONS, AND RECOMMENDATIONS

This chapter focuses upon the purpose, procedures, and results of this study, as well as the summary, conclusions, and recommendations that are outgrowths of the study.

\section{Summary}

The purpose of this study was to look at the status of middle school teachers in schools suburban to the city of Portland, Oregon, and to establish some baseline data about middle school teachers in the areas of job satisfaction, levels of morale, and levels of rapport and. status. These results were to be used to establish distinguishing characteristics about the middle school teachers or their similarities when compared to a norming sample provided by the Purdue Teacher Opinionaire (PTO). Specifically, the areas analyzed were:

1. Biographical data of the respondents;

2. The scores on the PTO and its subscales; and

3. The results of the Administrators' Questionnaire.

The teachers from four districts were drawn as part of the sample which consisted of teachers from nine different middle schools. Each school had a population not exceeding 
650 students and was from feeder areas that were predominantly white and lower middle to upper middle in economic level. Of the 268 questionnaires distributed, 173 were returned. Two were discarded due to insufficient information. This made the total sample 171 . Using the biographical data provided by the teachers as the independent variables and the scales of the PTO as the dependent variables, means, medians, and standard deviations were computed for the various scales and the biographical information when appropriate. Further analysis was made using analysis of variance and univariate analysis of variance with Scheffé tests as indicated when comparing means.

Analysis of the biographical data revealed that the most frequent respondent was a seventh or eighth grade teacher with a mean age of 40.240 years who was more likely to be female than male. It was likely that the teacher would be involved in instruction of Language Arts and have taught approximately 11.8 years. Nearly 20 percent of the respondents were in the first four years of teaching with the mode being 4 . Of the respondents, nearly 36.8 percent were in the first four years in their present position. The average respondent was more likely to have elementary certification than any other state certification (42.1\%), while none of the respondents possessed administrative credentials that were still valid. Proportionally more females 
possessed secondary certification, while considerably more males possessed both elementary and secondary certification simultaneously. Not suprisingly, high percentages of the respondents possessed degrees from oregon institutions of higher education and, due to the lack of offerings in these institutions pertaining to middle schools, low numbers of the respondents reported any training aimed at preparing them for jobs as middle school teachers (35.3\%).

The teachers in this sample scored the highest in the subscale scores for Rapport Among Teachers and lowest on Status. The respective means were 46.199 ( $82.5 \%$ of the possible points for the subscale) and $20.123(62.9 \%$ of the available points for the subscale). The sample mean for the total PTO score which measures morale was 308.368 . This is lower than the means obtained on the test/retest sample (312.49 and 311.28); however, the median of the norming sample (310.4) is lower than the median for this sample $(311.667)$.

There appears to be a significant relationship between scores for Satisfaction with Teaching expressed and the gender of the respondents, with the females being more highly satisfied than males (Hypothesis 4: Females in the sample will have higher scores on the subscale Satisfaction with Teaching than males). The same is true of the levels of Rapport with the Principal that were measured by the PTO (Hypothesis 5: Females will have higher scores on the the 
subscales relating to levels of rapport [Rapport with the Principal and Rapport Among Teachers]).

The scores for Rapport with the Principal also appear to have a significant relationship to the age of the respondent if the respondent is in the 45-65 year age range or Maintenance Stage of Gould's Career Stages (1979).

The subscale with the highest average score on a normative basis, Rapport Among Teachers, shows a significant relationship to the locale, or district and school, of the respondent.

As with Satisfaction with Teaching and Rapport with the Principal, the test scores for Morale are related to the gender of the respondent with the females demonstrating a significantly higher average score for Morale at both the school and district levels.

The results of the Administrators' Questionnaire indicated that the level of implementation of the characteristics of the middie schools is consistent with the levels as outlined by Riegle (1971) and Bolinger (1981) among others. In considering Hypothesis 6 (the levels of job satisfaction as determined by the scores on the PTO, will be lower in buildings where the principal has indicated a higher task orientation and less relationship orientation in his/her self-perceived management style analysis), it was difficult to find any relationship between the principals' self-perceived management styles and scores for Morale, 
Satisfaction with Teaching, or Rapport with the Principal. There was some tendency for the high relationship principal to have a low score in Rapport with the Principal, as hypothesized, and the principal with a balance of high task/high relationship to be the highest score on the Rapport with the Principal subscale.

The intercorrelations of the subscales on the PTO were sufficientiy small to provide assurance of meaningful assessment ( see Appendix B).

\section{Conclusion}

Although the literature was confusing on the delineation of job satisfaction and morale, this study indicates that the measurements are distinct from one another. This is best exemplified by the case of District 4 . The mean satisfaction score for District 4 was 68.21 , the highest among all four districts, while the mean score for Morale was 313.51 , the second highest score. The superintendent of this district perhaps went further to explain this dichotomy than any of the literature. He stated that it had been "a rough year," and he would expect morale to be down slightly. Additional support is lent to this by looking at the results from School 4 . School 4 has the highest level of Morale (mean $=322.87$ ) while it has only the fourth highest score on the Satisfaction with Teaching subscale (mean = $65.67)$. 
Satisfaction With Teaching.

Hypothesis 1: Those teachers in the first three years of teaching will have a lower score on the subscale Satisfaction with Teaching than teachers in other experiential levels.

Hypothesis 3: In the initial years of their careers, middle school teachers will have lowered scores on the subscale Satisfaction with Teaching (ages 22 to 30 years) followed by increased scores through the next career stage (ages 31 to 44 years), and, finally, lowered scores during the remaining years of their careers (ages 45 to 65 years). Hypothesis 4: Females in the sample will have higher scores on the subscale Satisfaction with Teaching than males.

Hypothesis 8: Districts which have suffered 1 abor re1 ations problems over the past five years will demonstrate lower scores on the Morale scale and the subscale for Satisfaction with Teaching.

The literature in the area of job satisfaction would indicate that, unlike the profiles for most workers (most are taken on blue collar employees), teachers appear to manifest a different profile with lowered levels of satisfaction in the first three years of employment followed by highly increased levels of satisfaction and lowered levels 
in the final twenty years of their career. That profile was supported by this sample. Although these results were not statistically significant, the pattern is similar to that found by Greenfield and Blase (1980) in their study of suburban New York secondary schools. These supportive findings would indicate that teachers are unique when compared to blue collar workers and even some studies of other professionals (Saleh, Shoukry, and otis, 1976). In support of the occupational uniqueness of teaching, England and Stein (1961) found large occupational differences in terms of item responses and this uniqueness indicates the importance of the occupational variable in attitude research and emphasizes the need for occupational norms. The sample in the present study and that of Greenfield and Blase (1980) have a common pattern indicating that teaching level may not influence the pattern; however, teaching as an occupational choice and the socialization process may differ from other professions.

In addition to this common profile shared by middle school teachers with other teachers, the teachers in the sample for the present study manifested the same tendency reported by Charters (1970) and Lortie (1975) for gender to influence the level of job satisfaction among teachers. In both of these studies (Charters, 1970; Lortie, 1975), there was a tie made to the fact that women, who are more satisfied with teaching, do not bring expectations of receiving their satisfaction from the job to teaching but obtained 
these satisfactions outside of the job. It is possible this is how satisfaction is obtained, but the only conclusion that the present study reached is that there is a significantly greater possibility $(p=0.021)$ of a female teacher obtaining a higher satisfaction score than a male. It is possible that this is connected to the characteristics of the females in this particular level of education, or, as Salancik and Pfeffer (1978) pointed out, it may be connected to the attitude of satisfaction brought to the job by the females. Such speculation is unjustifiable based on the scant information provided by the instrumentation employed in this study.

The levels of Satisfaction with Teaching are lowered by district involvement in a strike. District 3 is the only district in the sample that has actually experienced a strike in the last five years. Along with the anecdotal information that indicates some concern still exists in the minds of employees and administrators, the Satisfaction with Teaching and Morale scores for this district are lower than those obtained for the other districts in the sample (means of 64.67 and 298.35 respectively). The only other district with labor problems came close (". . Within three minutes -. ") (Principal Questionnaire - School 8) of striking, however, did not go to strike. This district had the second lowest Morale score (mean $=308.51$ ) and was only slightly edged out by another district for the same position in 
Satisfaction with Teaching (mean $=64.98)$. These findings would indicate that there may be a distinct relationship between existence of labor problems and teachers' feelings of satisfaction with their job and morale. Rather than mitigating these feelings through going to strike and receiving compensation for demands, it appears that the strike may have reduced positive feelings about their job. These findings would support the hypothesis that labor problems would have an impact on the feelings of job satisfaction and morale of the teachers.

Rapport with the Principal

It can be concluded that the results from this sample of middle school teachers support the hypothesis that female teachers manifest a significantly higher level of Rapport with the Principal than do male $(p=0.0310)$. These findings may be a function of higher levels of satisfaction with teaching manifested by females in this sample, or it may simply be a function of the socialization process for females which may differ from that of males and stress rapport as a more important value. Males may value competition over rapport and so score lower on the Rapport with Principal subscale. The level of Rapport with the Principal is also related in a significant way $(p=0.0461)$ to the locale (specifically to the school) of the respondent. It is possible that the score relationship to locale is linked to the 
managerial style of the principal. The highest level of rapport is from a school where the principal's managerial style was self-reported as a blend of high task and high relationship while the lowest score is from a school where the principal reported a high relationship style. Although somewhat mixed, the results from this comparison seem to indicate that one principal pointed out in the interview: the manager "must look for a match." Rapport with the Principal is one of the subscales where the sample scored consistently above the 50 th percentile when compared to the norming sample. This finding would indicate that middle school teachers in this sample are maintaining acceptable levels of rapport with their administrators. The total sample mean was 63.392 or $79.2 \%$ of the possible points available in this subscale.

Rapport Among Teachers

It is in the Rapport Among Teachers subscale that the sample respondents scored at proportionally the highest level of any of the subscales in the PTO (mean $=46.199,82.5 \%$ of total score possible, and median $=46.531$ as compared to norming sample median at 50 th percentile of 44.1). Again, as with Rapport with the Principal, there is a significant relationship between the locale and the level of Rapport Among Teachers (School, $p=0.0000$; district, $p=0.0001$ ). The subscale questions solicit responses that are related to 
and provide the respondent's opinions about the levels of "cooperation, preparation, ethics, influence, interests, and competency of peers" (Bentley \& Rempel, 1980, p. 4). The high level of the means would indicate that the middle school teachers in this sample have quite high regard for and good relations with their peers. This heightened regard might be the result of a "bunkering effect" since schools are frequently under attack in recent years from the outside; or it might be the result of genuine admiration and collegial feelings among the teachers. Whatever the cause of the result, it is a strength of the middle school teachers surveyed and provides an interesting insight into the nature of the relationship of teachers who are often felt to be isolated by differentiated programs. It is also possible that the isolation reinforced the peer rapport because of lack of contact with other teachers, since the level of team teaching is low in the sample schools with a mean reported implementation level of 4.56 out of a possible high of 10 .

\section{Teacher Status}

Hypothesis 7: Middle school teachers will demonstrate scores below the 50 th percentile of the norming sample on the subscale Teacher status.

Although the Teacher Status subscale was not found to be significantly related to any of the biographical data, it is interesting to note that it is consistently below the 
50 th percentile of the normin sample on all items and the lowest of the scores when proportionally compared to the total score possible (mean $=20.123,62.9 \%$ of possible score for subscale). Such low levels of status would support McEwin's (1980) postulate that the status of middle school teachers is affected by their lack of professional recognition by institutions at the state level including certifying bodies and universities. It is possible that status perception is unimportant to the preparation and maintenance of teachers for the middle school level, but it seems contradictory to the thrust of the middle school that aims for development of positive self-concepts and stresses affective goals for students. It is difficult to make the leap that McEwin did that official recognition for middle school teachers through state certification and university program development will increase levels of status. The assumption is that recognition is the source of status for middle school teachers. It is possible that the community, administrators, peers, family, and others may influence selfperceived status levels.

\section{Morale}

As with the subscales of Rapport with the Principal and Rapport Among Teachers, Morale is related to the locale of the respondent, but it also related to the gender of the respondent. Although this was not hypothesized, when 
separated for gender, the analysis of variance for the Morale scores by District and School of the respondent found a significant relationship for females only (District level, p $=0.0001$; School level, $p=0.012$ ). The increased scores among females may be related to the significantly higher levels of Satisfaction with Teaching and Rapport with the Principal that are associated with the females in this sample. It is possible that higher subscale scores in satisfaction and Rapport with Principal are enough to create. this relationship, but the significance is high and may also reflect a real relationship.

Age

Age is the only other biographical feature that is associated in any way with increased levels of Morale. Those respondents in the Maintenance Stage (Ages $=$ 45-64) (Gould, 1979) have higher levels of Morale. Depending upon the district, the relationship is significant $(p=0.0500)$. Those districts which manifest the highest level of morale for this group, also manifest the highest total scores for Morale among the four districts.

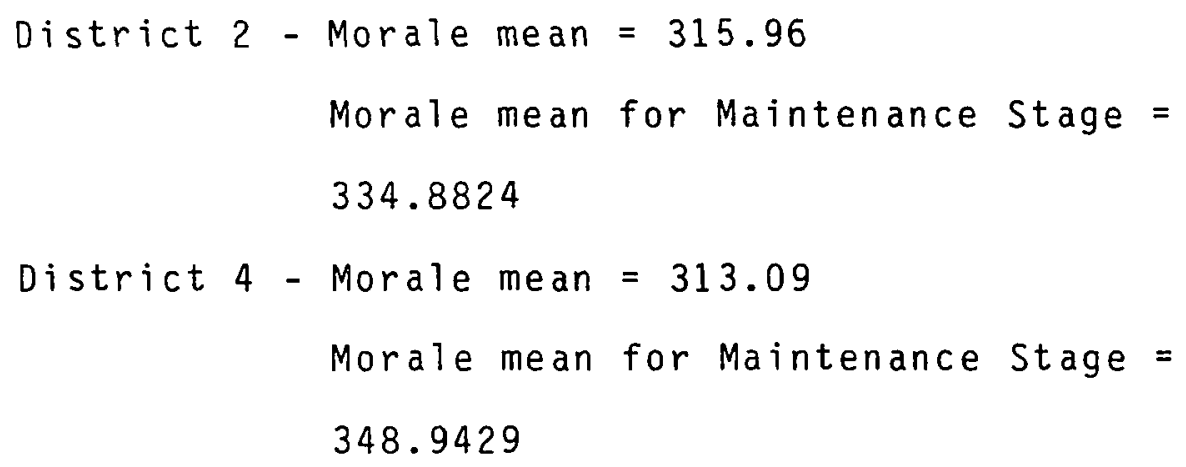


It is possible that the high level of significance is associated with differing policies in the districts as they relate to the employee in the Maintenance Stage, or that there are higher levels of security associated with the districts. The relationship is difficult to analyze and would take a different type of study to determine the causes of such a relationship.

\section{Limitations of the Study}

The present study presented some limitations that must be considered. These limitations include the geographic 10cation, specific historical events, and the subjectivity of the Administrators' Questionnaire.

\section{Geographic Location}

The teachers in nine middle schools in four school districts suburban to the city of Portland, Oregon, were included in the sample. There is no way to know if the same results would be obtained in another part of the country or even in an urban area or rural area.

\section{Historical Events}

In one of the schools (8) the principal of the school died within one month prior to the surveying of the teachers. The death may have had an effect on the validity of the results from that particular school. 
Subjectivity of Administrators' Questionnaire

The Administrators' Questionnaire called for the principals to provide a self-analysis of their managerial style and the levels of implementation of the eighteen middle school characteristics in their schools. Such self-analysis may have threatened the validity of these results, however, the threat would have been consistent throughout the sample.

\section{Additional Contributing Independent Variable}

One factor that may have affected the lowered levels of Morale and Satisfaction in District 3 is the use of year round school in that district. Although no particular comments were made about this variable in either anecdotal form or on the questionnaires, it is possible that the alteration in scheduling from the normal school year could have influenced the scores. Year-round school's effect might be especially influential for teachers in their first few years of teaching in this district, since the adjustment is a considerable change from the school year these teachers would be used to as students or as teachers in other districts.

\section{Implications of the Study}

The purpose of the study was to evaluate the status of middle school teachers in the sample and to establish some baseline data about those teachers. In addition, the data 
was studied to determine the levels of support provided by the study for various assumptions about job satisfaction, teacher status, and rapport relationships. The results of the study do suggest some implications for school districts and possibly for state certifying bodies and universities responsible for middle school teacher preparation.

1. If districts wish to hire teachers who are more likely to maintain higher levels of job satisfaction and morale, the results of this study support the findings of other research which indicates that females would be the best choice to hire.

2. Middle school teachers in the study have low levels of status when compared to the norming sample. These low levels would support the concept of McEwin that such lowered levels exist but there is no support provided for McEwin's connection of lowered status to lack of professional recognition through certification and supporting university programs to provide training for middle school teachers. It might be one solution to the low level of Teacher status to try providing this recognition to middle school teachers.

3. Perhaps the most significant implication of the present study is the finding that middle school teachers do not significantly differ from teachers in the norming sample of the PTO. The lack of significant difference means that middle school teachers are generally like other teachers in 
school districts in the areas measured by the PTO, and administrators can make decisions based on this.

\section{Recommendations for Further Research}

The results of the present study are limited by the geographical area sampled. One direction that further research might take would be to broaden the sample's locale to include not only suburban schools but urban and rural schools. Such broadening would provide a better picture of the middle school teacher and whether the results of the present study are connected to the suburban character of the schools.

It also became clear that a change in the type of instrumentation used to determine the dependent variables might have given a better picture of the unique character of the middle school teacher. One respondent even commented that he/she did not see ". . how this can tell anything about the uniqueness of us as middle school teachers." The instrumentation used provided baseline data to compare middle school teachers to other teachers at different levels but failed to draw out the uniqueness of middle school teachers.

The establishment of the source of the lowered status of middle school teachers as measured in this sample in comparison to the norming sample used to norm the PTO would also make an interesting study. The development of an 
instrument that would differentiate the source of the feelings of status would be needed for such a study. For example, the instrument would need to differentiate the status that is obtained from professional recognition from the status that is obtained from community attitudes and that from the status obtained from the attitude of family and friends. Such a study would lend greater credence to the claims of McEwin and others that middle school teachers should be recognized through specialized training and certification.

Finally, collection of data regarding the levels of absenteeism and the levels of job satisfaction and morale in districts could provide support for the concept that there is a connection between the productivity of the teachers and the levels of these dependent variables. 


\section{BIBLIOGRAPHY}

Adler, S. (1980). Self-esteem and casual attributes for job satisfaction and dissatisfaction. Journal of Applied Psychology, 65, 327-332.

Aldefer, C. P. (1969). An empirical test of a new theory of human needs. Organizational Behavior and Human Performance, $4,1 \overline{42-175 .}$

Aldefer, C.P. (1969). Job enlargement and the organizational context. Personnel Psychology, 22, 418-426.

Alexander, W. M., \& McEwin, C. K. (1982). Toward middle level teacher education. Middle School Journal, 15 , $3-5$.

Allen, H. A., \& Splittberger, F. L. (1980). Teachers' and principals' attitudes about the characteristics and functions of middle schools. Paper presented at the Annual Meeting of the Eastern Educational Research Association. New York. (ERIC Document Reproduction Service No. ED 206 086)

Argyris, C. (1964). Integrating the Individual and the organization. New York: John Wiley and Sons, Inc.

Argyris, C. (1973). Personality and organization theory revisited. Administrative Science Quarterly, 18, 141167 .

Ashton, P., Doda, N., Webb, R. B., Olejnik, S., \& McAuliffe, M. (1981). Middle school organization, teacher job satisfaction, and school climate. Fairborn, OH: $\mathrm{Na}-$ tional Middle School Association, Middle School Research. (ERIC Document Reproduction Service No. ED 215422 )

Ashton, P. J., Webb, R. B., \& Doda, N. (1982). A study of teachers' sense of efficacy (Final Report, Vol I). GainesviTle, FL: University of Florida, Foundation of Education. (ERIC Document Reproduction Service No. ED 231834 ) 
Beckman, V. C. (1981). A study to determine the current level of implementation of eighteen basic middle school principles in the state of Missouri. Fairborn, OH: National Middle School Association, Middle School Research. (ERIC Document Reproduction Service No. ED 214 273)

Bentley, R. R., \& Rempe1, A. M. (1963). Peer selection vs. expert judgement as a means of validating a teacher morale measuring instrument. The Journal of Experimental Education, 31 (3), 233-240.

Bentley, R. R., \& Rempel, A. M. (1980). Manual for the Purdue Teacher Opinionaire. West Lafayette, IN: Purdue Research Foundation.

Billings, R. L. (1973). A computer-based analys is of the implementation of selected criteria in Texas middle schools. Dissertation Abstracts International, 34/11A. (University Microfilms No. DCJ74-11855)

Blake, R. R., \& Mouton, J. S. (1981). The New Managerial Grid. Houston, TX: Gulf Publishing Company, Book Division

Blase, J. J., \& Greenfield, W. D. (1981). Interactive/ cyclical theory of teacher performance. Administrative Notebook, 29, 5, 1-4.

Bloom, J. M. (1974). The implementation of the middle school concept in Wisconsin schools for pre-and early adolescents. Dissertation Abstracts International, 35/04A. (University Microfilms No. DCJ74-22290)

Bohlinger, J. (1981). The current status of ohio middle schools implementation of eighteen middle school characteristics. Fairborn, OH: National Middle School Association, Middle School Research. (ERIC Document Reproduction Service No. ED 214 283)

Borg, W. R., \& Gall, M. D. (1983). Educational Research: An Introduction, (4th ed.). NY: Longman, Inc.

Brayfield, A. H., \& Crockett, W. H. (1955). Employee attitudes and employee performance. Psychological Bulletin, L11, 396-424.

Brayfield, A. H., \& Rothe, H. (1951). An index of job satisfaction. Journal of Applied Pscyhology, 35, 307311 . 
Brimm, R. P. (1969). Middle school or junior high school? Background and rationale. NASSP Bulletin, 53, 1-7.

Buros, 0. K. (Ed.). (1972). The Seventh Mental Measurements Yearbook, Vol. II. Highland Park, NJ: The Gryphon press.

Buros, 0. K. (Ed.). (1978). The Eighth Mental Measurements Yearbook, Vol. I. Highl and Park, NJ: The Gryphon Press.

Caldwell, D. F., \& O'Reilly, C. A. (1982). Task perceptions of job satisfaction: A question of causality. Journal of Applied Psychology, 67(3), 361-369.

Chapman, D. W. (1982). Career satisfaction of teachers. Educational Research Quarterly, $7(3), 40-50$.

Chapman, D. W., \& Hutcheson, S. M. (1982). Attrition from teaching careers: A discriminant analysis. American Educational Research Journal, 19(1), 93-105.

Chapman, D. W., \& Lowther, M. A. (1982). Teachers' satisfaction with teaching. Journal of Educational Research, 75, 241-247.

Charters, W. W. (1970). Some factors affecting teacher survival in school districts. American Educational Research Journal, $7,1-27$.

Cohen, E. G., Bredo, A., \& Duckworth, K. (1976). Organizational support for the teacher's role. In E. Cohen, J. Deal, J. Meyer, \& R. Scott (Eds.), Organization and Instruction in the Elementary School. Stanford, CA: Stanford Center for Research and Development on Teaching.

Cummings, R. R. (1975). The middle school concept and its implementation in the Commonwealth of PA. Dissertation Abstracts International, 37/02A. (Univerity Microfilms No. DCJ78-17159)

Cummings, L. \& Berger, C. (1976). Organizational structure: How does it influence attitudes and performance. Organizational Dynamics, $\underline{5}(2), 34-39$.

Daniel, J. C. (1973). A study of Arkansas middle schools to determine the current level of implementation of nine basic middle school principles. Dissertation Abstracts International, 34/07A. (Univeristy Microfilms No. DCJ 73-27368) 
DeMedio, D. L. \& Kish, J. P., Jr. (1980). A study of attitudes of teachers and principals toward middle schoor certification. Paper presented at the Midwestern Educational Research Association. Southwick, OH. (ERIC Document Reproduction Service No. ED 195 560)

Draud, J. E. (1979). The relationship between the organizational structure of middle school and junior high school and its effects on the attitude of teachers and students toward school. In The Middle School Research Annual, Laramie, WY: Center of Research, Services and Pubtications.

Dunette, M. D., Campbel1, J. P., \& Hakel, M. D. (1967). Factors contributing to job satisfaction and job dissatisfaction in six occupational groups. Organizational Behavior and Human Performance, $2, \overline{143-174 .}$

England, G. W., \& Stein, C. I. (1961). The occupational reference group - a neglected concept in employee attitude studies. Personnel Psychology, XIV, 299-304.

Erb, J. u. (Ed.). (1981). Middle School Research: Selected studies. Fairborn, OH: National Middie School Association. (ERIC Document Reproduction Service No. ED 215422 )

Erlandson, D. A., \& Pastor, M. C. (1981). Teacher motivation, job satisfaction and alternative-directions for principals. NASSP Bulletin, 65, 5-9.

Fielding, M. A., \& Gall, M. D. (1982). Personality and situational correlates of teacher stress and burnout. Paper presented at the Annual Meeting of the American Educational Research Association. New York. (ERIC Document Reproduction Service No. ED 219 353)

Fiynn, J. H. (1971). Practices of middle schools in California. Dissertation Abstracts International, $32 /$ 05A. (University MicrofiTms No. 71-27920)

Foa, U. G. (1957). Relation of workers expectations to satisfaction with supervisors. Personnel Psychology, $\underline{x}, 161-168$.

Franklin, C. (1973). A study of middle school practices in Virginia. Dissertation Abstracts International, 34/ 08A. (University Microfilms No. DCJ73-32436)

Gatewood, J. (1973). What research says about the middle school. Educational Leadership, 31(3), 221-224. 
George, P. S., \& McEwin, C. K. (1978). Middle school teacher education: A progress report. Journal of Teacher Education, XXIX (5), 13-16.

George, P. S., McMillan, M., Malinka, R. \& Pumerantz, P. (1975). Middle school teacher certification: A national survey. Educational Leadership, 33(3), 213216 .

Georgiady, N. P., Riegle, J. D., \& Romano, L. G. (1973). What are the characteristics of the middle school. The Middle School. Chicago: Nelson-Hall Company, 5-14.

Georgopoulos, B. S., Mahoney, G. M., \& Jones, N. W., Jr. (1957). A path-goal approach to productivity. Journal of Applied Psychology, 41(6), 345-353.

Gibson, J. L., \& Klein, S. M. (1970). Employee attitudes as a function of age and length of service: A reconceptualization. Academy of Management Journal, 13, $411-425$.

Gordon, J. S. (1981). A comparison of the attitudes of e1ementary, middle and high school teachers. In R. M. Malinka (Ed.), Middle School Research: Selected Studies, 1977-1979, Vol. III, pp. 24-30, Fairborn, OH: National MiddTe School Association.

Gould, S. (1979). Age, job complexity, satisfaction and performance. Journal of Vocational Behavior, 14, 209223 .

Gould, S., \& Hawkins, B. L. (1978). Organizational career stage as moderator of the satisfaction-performance relationship. Academicy of Management Journal, 21, 434450 .

Greene, C. N. (1975). The satisfaction performace controversey. In R. M. Steers \& L. W. Porter (Eds.), Motivation and Work Behavior. New York: McGraw-HilT.

Greenfie?d, H., 足 Plase, J. J. (1381). Motivating teachers: Understanding the factors that shape performance. NASSP Bulletin, 65, 1-10.

Gruneberg, M. M. (1976). Job Satisfaction-A Reader. New York: John Wiley \& Sons.

Guba, E. G. (1958). Role, personality and social behavior, as quoted in Bentley, R. R. \& Rempel, A. M. (1980). Manual for the Purdue Teacher Opinionaire. West Layfayette, IN: Purdue Research Foundation. 
Hackman, J.R., \& Lawler, E. E. III. (1971). Employee reactions to job characteristics. Jcurnal of Applied Psychology, 55, 259-286.

Herman, J., Dunham, R., \& Hulin, C. (1975). Organizational structure, demographic characteristics and employee responses. Organizational Behavior and Human Performance, $13,20 \overline{6-232}$.

Herman, J. B., \& Hulin, C. L. (1973). Managerial satisfactions and organizational roles on investigation of Porter's need deficiency scales. Journal of Applied Psychology, 57, 118-124.

Herzberg, F. (1976). The Managerial Choice: To Be Efficient and to Be Human. Homewood, IL: Dow JonesIrvin.

Herzberg, F. (1966). One more time: How do you motivate employees. Harvard Business Review, 46, 53-62.

Herzberg, F. (1966). Work and the Nature of Man. Cleveland, $\mathrm{OH}$ : World Publishing Co., Inc.

Herzberg, F., Mausner, B., Peterson, R. 0., \& Capwe11, D. F. (1957). Job attitudes: Review of Research and Opinion. Pittsburgh, PA: Psychology Services of pittsburgh.

Herzberg, F., Mausner, B., \& Smjderman, B. B. (1959). The Motivation to Work. New York: John Wiley and Sons, Inc.

Holland, J. I. (1973). Making Vocational Choices: A Theory of Careers. Englewood Cliffs, NJ: PrenticeHaTl.

Hornstein, H. A., Callahan, D. M., Fisch, E., \& Benedict, B. A. (1968). Influences and satisfaction in organizations: A replication. Sociology of Education, 41, $380-389$.

Hulin, C. L., \& Smith, P. C. (1964). Sex differences in job satisfaction. Journal of Applied Psychology, XLVIII $(2), 88-92$.

Hunt, J. W., \& Saul, P.N. (1975). The relationship of age. tenure and job satisfaction in males and females. Academy of Management Journal, 690-702. 
Johnston, J. H., \& Markle, G. (Eds.) (1980). Middle School Research: Selected Studies 1977-79. Fairborn, OH: National Middle School Association. (ERIC Document Reproduction Service No. ED 199819 )

Klein, S. M., \& Maher, J.R. (1968). Education level, attitudes and future expectations among first-level management. Personnel Psychology, 21, 43-53.

Kramer, J. W. (1974). A study of middle school practices in California. Dissertation Abstracts International, 35/05A. (University Microfilms No. DCJ74-13828)

Kuhlin, R. G. (1963). Needs, percevied needs, satisfaction and satisfaction with occupation. Journal of Applied Psychology, 47,56-64.

Kyriacon, C. \& Sutcliffe, J. (1979). Teacher stress and satisfaction. Educational Research, 21, 89-96.

Lawler, E. III. (1969). Job design and employee motivation. Personnel Psychology, XXII, 426-435.

Lawler, E. E. III, \& Porter, L. W. (1967). Antecedent attitudes of effective managerial performance. Organizational Behavior and Human Performance, 2, $122-142$.

Lawler, E. E. III, \& Porter, L. W. (1967). The effects of job performance on job satisfaction. Industrial Relations, 6 , 20-28.

Lee, R. (1982). Moderating the effect of sex on the prediction of job satisfaction. Journal of Employment Counseling, $19,34-44$.

Lee, R. Mueller, L. D., \& Miller, K. J. (1981). Sex, wageearner status, occupational level and job satisfaction. Journal of Vocational Behavior, 18, 362-373.

Levitor, J., \& Wangberg, E. (1983). Identifying factors of teacher stress and job satisfaction. Thrust, 12, 2021 .

Locke, E. (1969). What is job satisfaction? Occupational Behavior and Human Performance, 4 , 309-336.

Lonsdale, R. C. Maintaining the orgdanization in dynamic equilibriums, as quoted in Bentley, R. R. \& Rempel, A. M. (1980) Manual for the Purdue Teacher Opinionaire. West Layfayette, IN: Purdue Research Foundation. 
Lortie, D. C. (1975). School-teacher. Chicago: University of Chicago Press.

Lounsbury, J. H., \& Vars, G. F. (1980). The Middle School in Profile: A Day in the Seventh Grade. Fairborn, OH: National Middle School Association.

Maslow, A. H. (1943). A theory of human motivation. Psychological Review, 50, 370-396.

Maslow, A. H. (1954). Motivation and Personality. New York: Harper.

Maslow, A. H. (1970). Motivation and Personality, (2nd ed.). New York: Harper and Row, Publishers.

McEwin, C. K. (1983). Middle level teacher education and certification. NASSP Bulletin, 67, 78-82.

McEwin, C. K., \& Alexander, W. M. (1982). The Status of Middle/Junior High School Teacher Education Programs: A Research Report. Boone, NC: Appalachian State University. (ERIC Document Reproduction Service No. ED 228173 )

McEwin, C. K., \& Allen, M. G. (1983). Middle Level Teacher Certification: A National Survey. Boone, NC: AppaTachian State University.

McEwin, C. K., \& Thomason, J. (1982). Increasing effectiveness in middle grades schools. A study of: Developmental characteristics, effective teacher competencies, implications for curriculum and instruction. Boone, NC: Appalachian State University. (ERIC Document Reproduction Service No. ED 212 086)

Medved, J. A. (1982). Applicability of Herzberg's Motivation-hygiene Theory. Educational Leadership, 39, 555.

Metzger, D. J., \& Wangberg, E. G. (1981). Many female teachers would choose other jobs. Phi Delta Kappan, $\underline{63}, 213$.

Meyer, J. \& Cohen E. (1971). The Impact of the Open-space School Upon Teacher Influence and Autonomy: The Effects of an Organizational Innovation. Stanford, $C A$ : Stanford University. (ERIC Document Reproduction Service No. ED 062-291) 
Mitche11, J. V. (Ed.) (1983). Tests in Print III. Lincoln, NE: The Buros Institute of Mental Measurement.

National Education Association, Research Division. (1981). Job satisfaction: Teacher opinion poll. Today's Education, $\underline{70}, 65$.

Norusis, M. J. (1982). SPSS Introductory Guide: Basic Statistics and Operations. New York: McGraw-HiT Book Company.

O'Reilly, C. A. (1977). Personality-job fit: Implications for individual attitudes and performance. Organizational Behavior and Human Performance, $18, \overline{36-46 .}$

O'Reilly, C. A., \& Caldwell, D. J. (1979). Informational influences as a determinant of task characteristics and job satisfaction. Journal of Applied Psychology, 64, 157-165.

O'Reilly, C. A., \& Roberts, K. (1975). Individual differences in personality, positions in organization, and job satisfaction. Organizational Behavior and Human Performance, $14,144-150$.

Phelps, S. (1975). A survey of middle schools in Georgia with a view of the beginning, present, and future status. Dissertation Abstracts International, 36/07A. (University Microfilms No. DCJ75-29905)

Pook M. E. (1981). A study of the relationship of teacher satisfaction and the level of implementation of recommended middle school practices. In T. O. Erb (Ed.), Middle School Research: Selected Studies (pp. 99107). Fairborn, OH: National Middle School Association. (ERIC Document Reproduction Service No. ED 215 422)

Porter, Lyman. (1981). A study of perceived need satisfaction in bottom and middle-management jobs. Journal of Applied Psychology, 45, 1-10.

Porter, L. W. and Lawler, E. E. (1958). Managerial Attitudes and Performance. Homewood, IL: Ricard D. Irwin, Inc.

Pumerantz, Phillip. (1969). Few states certify teachers for the growing middle schools. Phi Delta Kappan, LI (2), 102 . 
Rabinowitz, S. \& Hall, D. J. (1981). Changing correlates of job involvement in three career stages. Journal of Vocational Behavior, 18, 138-144.

Raymer, J. T. (1974). A study to identify middle schools and to determine the current level of implementation of eighteen basic middle school characteristics in selected United States and Michigan schools. Dissertation Abstracts International, 35/09A. (University Microfilms No. DCJ 75-07239)

Redecki, H., \& Evans, S. (1982). The teacher strike study. Sudbury, Ontario: Ontario Department of Education, Toronto. (ERIC Document Reproduction Service No. ED 232 274)

Rempel, A. M., \& Bentley, R. R. (1964). The measurement of teacher morale: A factor analys is approach. Educational and Psychological Measurement, XXIV (3), $631-$ 642 .

Riegle, J. D. (1971). A study of middle school programs to determine the current level of implementation of eighteen basic middle school principles. Dissertation Abstracts International, 32/06A. (University MicrofiTms No. DCJ 71-31295)

Roethlisberger, F. J., \& Dickson, W. J. (1939). Management and the Worker. Chicago: Howard University Press.

Ruch, R. S. (1979). Path analytic study of the structure of employees job satisfaction: The critical role of top management. Journal of Vocational Behavior, 15 , 277-293.

Rush, J. C. (1980). Career stages: A partial test of Levinson's model of life/career stages. Journal of Vocational Behavior, 16, 347-359.

Salancik, R., \& Pfeffer, J. (1977). An examination of need satisfaction models of job attitudes. Administrative Science Quarterly, 22; 427-456.

Salancik, R. \& Pfeffer, J. (1978). A social information processing approach to job attitudes and task design. Administrative Science Quarterly, 23, 224-253.

Saleh, S. D., Shoukry, D., \& 0tis, J.L. (1964). Age and level of job satisfaction. Personnel Psychology, 17 (4), 425-430. 
Sarason, S. B. (1978-79). Again the preparation of teachers: competency and job satisfaction. Interchange, $10(1), 1-11$.

Schwab, D. P., \& Wallace, M. J., Jr. (1974). Correlates of employee satisfaction with pay. Industrial Relations, $\underline{13}(1), 78-89$

Sergiovanni, T. J. (1977). Handbook for Effective Department Leadership: Concepts and Practices in Today's Secondary Schools. NY: Allyn and Bacon.

Sergiovanni, T.J. (1979). Supervision: Human Perspectives, (2nd ed.). NY: McGraw-Hill.

Sergiovanni, T. J. (1980). Educational Governance and Administration. NY: Prentice-HalT.

Sergiovanni, T, J. (1980). The New School Executive: A Theory of Administration, (2nd ed.). NY: Harper and Row.

Sergiovanni, T. J. (1982). Supervision of Teaching. Alexandria, VA: Association for Supervision and Curriculum Development.

Smith, C. L., \& Hulin, C. L. (1964). Sex differences in job satisfaction. Journal of Applied Psychology, XLVIII (2), 88-92.

Smith, P., Kendall, L., \& Hulin, C. (1969). The Measurement of Satisfaction in Work and Retirement. Chicago, IL: Rand MCNaTTy.

Stogdill, R. (1981). Handbook of Leadership. NY: Free Press.

Stumpf, S. A., \& Rabinowitz, S. (1981). Career stage as a moderator of performance relationships with facets of jobs satisfaction and role perceptions. Journal of Vocational Behavior, 18, 202-218.

Sweeney, J. (1981). Teacher dissatisfaction on the rise: Higher level needs unfulfilled. Education, 102, 203208.

Thierbach, G. L. (1980). Decision involvement and job satisfaction in middle and junior high schools. Dissertation Abstracts International, 41/09A. (University Microfilms No. DEN80-20587) 
Vockell, E. L. (1983). Educational Research. NY: MacMillan Publishing Co., Inc.

Vollmer, H. M., \& Kinney, J. A. (1955). Age, education, and job satisfaction. Personnel, 32, 38-43.

Vroom, V. H. (1964). Work and Motivation. NY: John Wiley and Sons, Inc.

Waggoner, J. C. (1983). Metropolitan school administrators: Work values, role perceptions and burnout. UnpubTished doctoral dissertation, Portiand State University/University of Oregon.

Wax, Anne Skirven. (1983). An investigation of the reliability, subscale intercorrelations, and validity of the administrator role perception inventory. Unpublished doctoral dissertation, Portland State University/University of Oregon.

Zaremba, J. P. (1979). Relationship of teacher motivation to innovativeness and job satisfaction. Dissertation Abstracts International, 40/05A. (University Microfilms No. DEL79-18180) 
APPENDIX A

Instruments 
To the Respondent:

Middle school teachers are special people and as such should be given a chance to voice their feelings about their jobs. This is an invitation to participate in a study of the middle school teachers. Your response to the study will take twenty to twenty five minutes and will shed some light on the needs and attitudes of middle school teachers in districts like yours.

The questions look at your level of job satisfaction and morale and how this is related to such things as state certification and training. It is better not to ponder over the questions but to answer them quickly with the first thought that comes to mind. This is because the questions are designed to test feelings not knowledge. When you have completed this survey, please return it to your school office. I would appreciate the return of the questionnaire by April 25. Please feel free to request a summary of the study findings by signing up in your school office or by contact me at:

3037 Arbor Drive West Linn, Oregon 97068 
Thank you for your cooperation and assistance. Your response reinforces my high level of respect for those people who have been my colleagues for many years - middle school teachers.

Susan Scott-Miller 


\section{THE PURDUE TEACHER OPINIONAIRE}

Preporod by Kalph K. Bentloy and Avorno M. Rempel

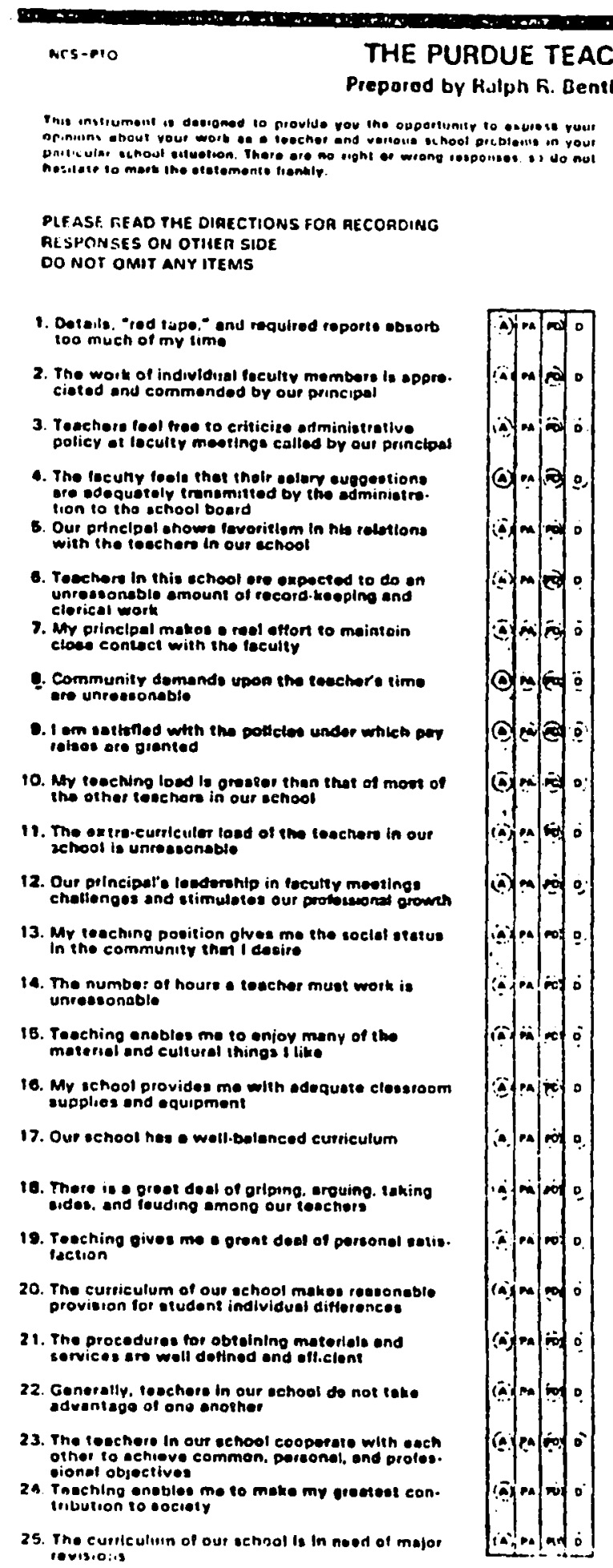

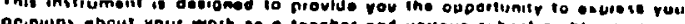

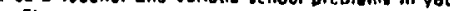

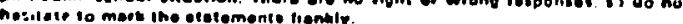

DLFASE. TEAD THE DIaECTIONS FOR hECOROING RLSPONSES ON OTHER SIDE

Defols. "red tippe" end required reporte nosort Wur princloel shown tevoritem in his reletions

Tecehore In this echool ore exoucted to to on

My princlpal makos o real afton to mainto I om estefled wht the pottetes undar which bey

0. My touenng loed le oreater then that of mom of

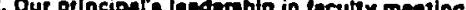
Mr teeching position olyes me the soctst status My echool provides me with edequete clesereom

There is oreet deal of orlping erouing laking Generally, tenchere in our techool do not take

23. The toochers In our tehool cooperate with oneh other to echieve commen. pareonal, and protes. Tanehing onabl

5. The curitculien of ouf echrol is in nead of major revis:o:4
PLEASE BILL IN THE FOLLOMNG INIUAMATION: SCHOOL:

DATE: ${ }_{\text {OCOPMUMT }}^{\text {ACE: SEX: }}$

30. Ilove to reech

27. II I could plen my corees eodn, I wowld choose eocting

28. Enperienced feculey mombers sceepl new and younger members as culleagues

22. I wacld recommend toceting we of occupotion 10 otudents of high echolostic ability

30. 11 I coutd earn es much moany in enoiner oceupa. Ilon, I would stop tauching

31. The we hool senedule pleces mp clences ot a dis. edveatede

32. The schoot inten to follow a penerous policy brolesenonel tisuel. prolesulonal study. otc.

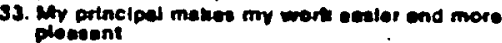

34. Koepting up prosostoncty is tee much of o burdon

38. Out community maltos lis teschare feol os though they ore e real part of the community

36. Satery polkelee ere edmindetered with toirness and untice

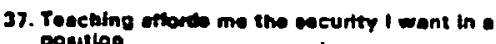

38. My sehool princlpal undertrende and recognizes good teeching procedutes

39. Teechere cleelly understend the policien goveming Delery incioseses

40. My clesses ore uned as a "dumping ground" for problem aludente

1. The lines and methods of communichtion between teachers end the principal in our sehoot are well dovoloped and mainisined

a2. My toeching lood in this echool is unressonsble

43. My principal ehows o ceel interest in my depert. ment

44. Our mincipal promotos sseme of betongine among she teschers in our schaol

as. My haevy teeching toed unduly mollite my non. plolesenonal ectivltioes

16. I find my contecest with studente, for the most part highly estietring and rewaruing

47. Ileal thet I om en importent pon ol this echool rotem

10. The ompotoney of ieseners in our echool compares fevorebly with that of tesehers in other echoole that Innow

9. My school providoe ine teschers wilh ednquote audio visual aide und projection equipmens

60. 1 feel sucreesfut and competent in my niesent

colsnnations

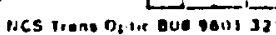


CTIONB FOR RECOADING RESPONSES ON OPINIONAIIIE

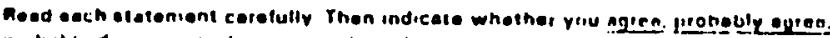

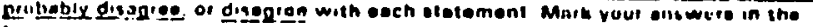
lollowing menner.

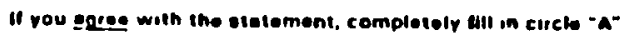
If you ore soinewhat uncertern, but peghebly egice with the slatement. enmpietely cill in circle "PA"

If you evo somowlies uncertein. but probebly disegreg with the etotement. cumptotely till in circle "PO"

If you disentee with ine osetement, completely fult in circle -o"

1. I enjor working with ofucent orgenizalions, elube. end socielies

B2. Our teeching steft is congenisl to work with

53. My toeching escociaten are wall prepeted for then iobs

B4. Out achool toculty hae o tendoncy to torm lato cliques

Es. The tesechers in ow echool wook well sogether

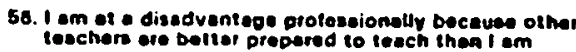

57. Our echool provides edoquate clerieal anrvices lor ine resechers

56. As far on I know. the olket toections think I am good tescher

85. Librery fecillibs and resources are edequate for the orade of eubject oree which I teech

60. The "etrese end etrein" resulting from teeching makes seaching undeslroble tor me

61. My principal is concermed with the problems of the teculty and mandies theee problems ermpathetically

62. I do not hasitere to discuse em school problem wilh my prineipal

63. Toeching gives me the preatige I deaire

64. My teaching job enables me to provide entis. tectory etenderd of living lot my tamily

65. The celery sehodule in our sehool edequetoly recoomzes teacher compotency

66. Mott of the people in this community underatend and eppieciete good education 67. In my juogment, this community is o goos plece to

4. This community respocts lis seschere and troate them lite prolessional persone

10. My prine ipol acte en though he le interested in me and my problem.

70. My echoot principal auperwhes cather then "enoopervises" the taechors in out echoo

71. It is dimicult Nop toechere to gain aceoptence by the poople in inis community

72. Teechers' meetings es now cenducted by oul principul weste the lume and eneigy of the stait

73 My principal has e ressoneble unteratending of the problems connected with my teseching eseronment

74. I feel that my wort lo ludaed fairly by my principal

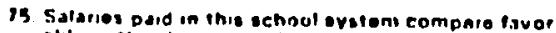
iuly wiln ealariot in olhel evateme with which

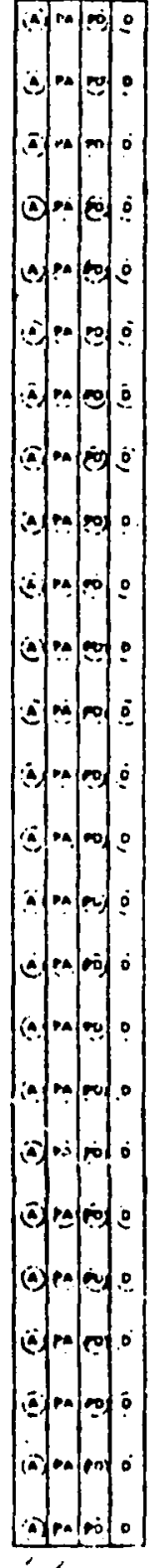

78. Moet of the ections of studente lritate me

77. The ceoperetiveness of tepcthare in ow schoot holpe makte my work more enjoyedle

70. Mr studente regarid me with respect and coem to hove conludence in my prolessionel ebility

70. The purposes end oblectives of ine echool

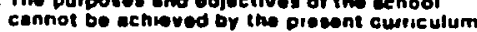

0. The teactron in our echool have a doniroble influence on the velues end ettitudes of their studonte

e1. This community expecte its tosenare 10 meot unresesonablo percenel stenderts

62. My etudente appreclate the holp I give thom with their uchool wort

e3. Te me thare to no more challemging work than tesening

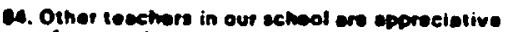
of my wort

15. As a teschar in this community my nonprotes. sional ectivities outside of setsool ene unduly rentilctod

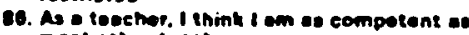
moet othat teechers

97. The tesehars with whom I wort mewe high professional ethice

88. Our echool curriculum does a 1000 job of preparing studente to become enlightened end

99. 1 really enjor worting with my etudents

90. The tesechers in our sechool ahow o great dent of initiotive and crestivity in theit

91. Teachors in our community tool free to discues controvernied iesues in thair claseses

92. My prinelpel trice to make me foel comtertable when he viuts my cleseses

03. My princlpol mntros efroctive vee ol the individ. und iencharis copecity ond tavent

14. The people in thle communliy, generally. heve a sincere end wholohoarted interest in the echool evatom

95. Taechere Peel pree to do to the principel ubout probleme of persenal and group weltere

90. Thie communify oupports othleal procedures regarding the appointment end respoeintment of the toeching etaft

07. This community le willine to aupoort 0000 progrem of oducetion

98. Our conimunity onpects tho teschere to portic ipoto in too many eecial eclivilies

99. Community preasures provent me from doing nir hast os steacher

100. 1 am wull sotiafied with my presert tedehing piration

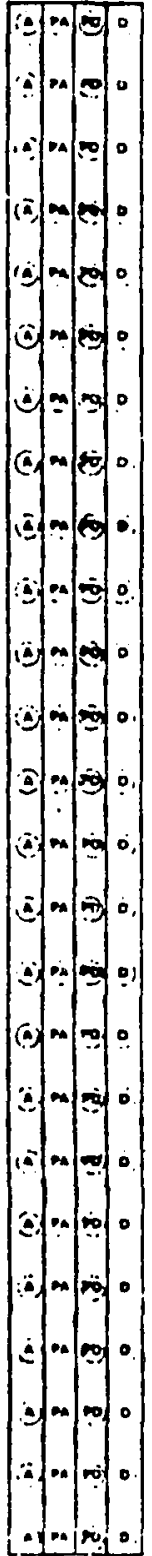


Schid

Distid

In id

DEMOGRAPHIC DATA

1. Grade level(s) you are teaching

2. Subject area(s) you are teaching

$(6-17)$

3. Age $(18-19)$

4. Male Female (20)

5. How many years have you held your present teaching position? $(21-22)$

6. How many years have you taught in the middle or junior high school level? $(23-24)$

7. What is the level of certification trat you have in the state of Oregon?

Elementary

Secondary Specialist

(please list the area of specialization $(26)$

8. Have you ever held any other certification? Yes No (31)

If so, what was that certification? $(32-36)$

9. Are you a graduate of an oregon college or university? Yes No (37)

If yes, what is the institution(s) from which you obtained a degree(s)?

$(38-26)$

10. Have you had any training which directly prepared you for teaching at the middle school or junior high school level before you began teaching at this level? Yes No (47)

If yes, was this training at the graduate or undergraduate level?

Graduate Undergraduate $(48-49)$ 


\section{ADMINISTRATORS ' QUESTIONNAIRE}

School

District

Principal

Date

Time of Day

Location of Interview

School Code Number 
Very briefly, I would like to ask you about the history of this school and your role with the school.

1. How long have you been the principal of this school? years

2. How long has this school been a middle school? years

3. Has the district faced any major funding problems in the last five years? Yes No

If yes: what kinds of problems, specifically?

4. Has the district faced any major labor relations problems in the last five years? Yes No

If yes: please explain:

5. Could you briefly explain your philosophy regarding the middle school concept: 
On a scale of 1-10, with 1 being the lowest level of implementation and 10 total and successful implementation, rate the levels of implementation that exist in your school at this time.

Rating

Continuous progress non-graded organization that allows students to progress at their own individual rate regardless of chronological age.

Multi-material or multi-media approach to instruction.

Flexible schedules.

Social experiences that are, in your opinion, appropriate to tranescent youth.

Physical and intramural activities based solely on the needs of students.

Team teaching.

Planned gradualism to ease the transition from childhood dependence to adult independence. Exploratory and enrichment studies.

- Guidance services (this includes an advissee-advisor program)

Independent study available to students.

Basic skill repair and extension.

Creative experiences.

Security factor that meets the students' needs for a security group.

Evaluation that is personal, positive, nonthreatening, and individualized.

Community relations program that is two-way.

Broad spectrum of student services.

Auxiliary staffing to provide individual help to students.

Effective communication within grades.

Effective communication across grade levels.

Effective communication across disciplines. 
Now that you have rated this level of implementation of each of these areas, I would like to go back to each one separately and discuss with you the ways in which each has been implemented in your school:

Continuous progress, non-graded organization that allows students to progress at their own individual rate regardless of chronological age.

Multi-material or multi-media approach to instruction

Flexible schedules 
Social experiences that are, in your opinion, appropriate to tranescent youth

Physical and intramural activities based soley on the needs of students

Team teaching

Planned gradualism to ease the transition from childhood dependence to adult independence 
Exploratory and enrichment studies

Guidance services (this includes an advisee-advisor progam)

Independent study is available to the students

Basic skills repair and extension 
Creative experiences

Security factor that meets the students' needs for a security group

Evaluation that is personal, positive, nonthreatening, and individualized 
Broad spectrum of student services

Auxiliary staffing to provide individual help to students

Effective communication within grades

Effective communication across grade levels 
Effective communication across disciplines

Finally, I would like to talk to you about your personal management style as you perceive it. Could you describe your style and briefly explain why you feel this is the most effective style for you.

Are there any other comments that you would like to make that you feel might be important to understanding your school or areas of development that you feel are significant that may not have been touched on during this interview? 


\section{DESCRIPTION OF THE FACTORS (SUBSCALES) OF THE PTO}

"Teacher Rapport with the Principal" deals with the teacher's feelings about the principal - - his professional competency, his interest in teachers and their work, his ability to communicate, and his skill in human relations.

"Satisfaction with Teaching" pertains to teacher relationships with students and feelings of satisfaction with teaching. According to this factor, the high morale teacher loves to teach, feels competent in his job, enjoys his students, and believes in the future of teaching as an occupation.

"Rapport Among Teachers" focuses on a teacher's relationship with other teachers. The items here solicit the teacher's opinion regarding the cooperation, preparation, ethics, influence, interests, and competency of his peers.

"Teacher Salary" pertains primarily to the teacher's feelings about salaries and salary policies. Are salaries based on teacher competency? Do they compare favorably with salaries in other school systems? Are salary policies administered fairly and justly; do teachers participate in the development of these policies?

"Teacher Load" deals with such matters as record keeping, clerical work, "red tape, "community demands on teacher time, extra curricular load, and keeping up to date professionally.

"Curriculum Issues" solicits teacher reactions to the adequacy of the school program in meeting student needs, in providing for individual differences, and in preparing students for effective citizenship.

"Teacher Status" samples feelings about the prestige, security, and benefits afforded teaching. Several of the items refer to the extent to which the teacher feels he is an accepted member of the community.

"Community Support of Education" deals with the extent to which the community understands and is willing to support a sound educational program.

"School Facilities and Services" has to do with the adequacy of facilities, supplies and equipment, and the efficiency of the procedures for obtaining materials and services. 


\begin{abstract}
"Community Pressures" give special attention to community expectations with respect to the teacher's personal standards, his participation in outside-school activities, and his freedom to discuss controversial issues in the classroom.
\end{abstract}

Source: Bentley and Rempel (1980), p. 4 . 


\begin{tabular}{|c|c|c|c|c|}
\hline MONDAY & TUESDAY & WEDNESDAY & THURSDAY & FRIDAY \\
\hline 2 & $\begin{array}{l}3 \\
\text { School \#1 } \\
\text { Teachers } \\
\text { and Prin } \\
\text { Interview }\end{array}$ & $\begin{array}{l}4 \\
\text { School \#2 } \\
\text { Teachers } \\
\text { and Prin } \\
\text { Interview }\end{array}$ & 5 & $\begin{array}{l}6 \\
\text { School \#3 } \\
\text { Teachers } \\
\text { and Prin } \\
\text { Interview }\end{array}$ \\
\hline $\begin{array}{l}9 \\
\text { School \#4 } \\
\text { Teachers } \\
\text { and Prin } \\
\text { Interview }\end{array}$ & $\begin{array}{l}10 \\
\text { Schools \#5 } \\
\text { and \#6 } \\
\text { Teachers } \\
\text { and Prin } \\
\text { Interview }\end{array}$ & 11 & 12 & 13 \\
\hline $\begin{array}{l}16 \\
\text { School \#7 } \\
\text { Teachers } \\
\text { and Prin } \\
\text { Interview }\end{array}$ & 17 & $\begin{array}{l}18 \\
\text { School \#9 } \\
\text { Teachers } \\
\text { and Prin } \\
\text { Interview }\end{array}$ & 19 & 20 \\
\hline 23 & 24 & 25 & 26 & $\begin{array}{l}27 \\
\text { School \#8 } \\
\text { Teachers } \\
\text { and First } \\
\text { Part of } \\
\text { Prin } \\
\text { Interview }\end{array}$ \\
\hline
\end{tabular}

Figure 15. Study calendar for April 1984. 


\section{APPENDIX B}

Miscellaneous Response Statistics 


\section{FACTOR IDENTIFICATION}

1. Teacher Rapport with the Principal

2. Satisfaction with Teaching

3. Rapport Among Teachers

4. Teacher Salary

5. Teacher Load

6. Curriculum Issues

7. Teacher Status

8. Community Support for Education

9. School Facilities and Services

10. Community Pressures 
Measurement Characteristics of the PTO

The inter-factor correlations for this sample were computed to establish whether they were sufficiently low in this case, as they were in previous norming samples, to make the factor scores meaningful in assessing the status of morale for a respondent or the sample as a whole group. For the most part the correlations appear to be low enough to make such an assessment meaningful. The correlations range from a low of .13 to a high of .61 with a median of approximately.31. These correlations are presented in Table LXII.

TABLE LXIII

INTER-FACTOR CORRELATIONS*

\begin{tabular}{ccccccccccc}
\hline FACTOR & 1 & 2 & 3 & 4 & 5 & 6 & 7 & 8 & 9 & 10 \\
\hline 1 & - & 41 & 31 & 30 & 27 & 28 & 23 & 24 & 30 & 13 \\
2 & & & 46 & 23 & 35 & 31 & 45 & 38 & 31 & 31 \\
3 & & & & 28 & 24 & 45 & 30 & 46 & 39 & 25 \\
4 & & & & & 23 & 24 & 54 & 45 & 28 & 24 \\
5 & & & & & & 44 & 40 & 29 & 33 & 47 \\
6 & & & & & & & 35 & 32 & 46 & 29 \\
7 & & & & & & & & & 23 & 42 \\
8 & & & & & & & & & & 33 \\
9 & & & & & & & & & & \\
10 & & & & & & & & & & \\
\hline
\end{tabular}

*Decimals omitted 
TABLE LXIV

SCORES OF SCHOOLS ON REMAINING SUBSCALES OF PTO

\begin{tabular}{|c|c|c|c|c|c|c|c|c|c|c|c|c|}
\hline \multirow{2}{*}{ SCHOOL } & \multicolumn{2}{|c|}{ SALARY } & \multicolumn{2}{|c|}{ LOAD } & \multicolumn{2}{|c|}{ CURR I CULUM } & \multicolumn{2}{|c|}{ COMMUN I CAT } & \multicolumn{2}{|c|}{ FACILITIES } & \multicolumn{2}{|c|}{ PRESSURES } \\
\hline & MEAN & $\begin{array}{l}\text { ST } \\
\text { DEV }\end{array}$ & MEAN & $\begin{array}{l}\text { ST } \\
\text { DEV }\end{array}$ & MEAN & $\begin{array}{l}\text { ST } \\
\text { DEV }\end{array}$ & MEAN & $\begin{array}{l}\text { ST } \\
\text { DEV }\end{array}$ & MEAN & $\begin{array}{l}\text { ST } \\
\text { DEV }\end{array}$ & MEAN & $\begin{array}{l}\text { ST } \\
\text { DEV }\end{array}$ \\
\hline 1 & 2 & & & & & & & & & & & \\
\hline 2 & 18.724 & & & & & & & & & & & \\
\hline 3 & 20.000 & & & & & & & & & 3.391 & 22 & \\
\hline 4 & 19.826 & & & & 17.8 & & & & & 2.240 & 17.174 & \\
\hline 5 & 20.000 & & & & 16. & & & & & 2.214 & 1 & \\
\hline 6 & 17.929 & & & & & & & & & 4.274 & 14 & \\
\hline 7 & 19.318 & & 35.273 & 5.461 & 16.727 & 2.781 & 13.364 & & 17.727 & 1.751 & 17.864 & \\
\hline 8 & 17.211 & 3.457 & 33.263 & 4.629 & 15.000 & 1.915 & 13.263 & 1.915 & 15.211 & 2.780 & 16.053 & \\
\hline 9 & 16.364 & 5.178 & 32.091 & 5.282 & 13.455 & 4.329 & 11.727 & 3.667 & 14.955 & 2.984 & 16.364 & 2.237 \\
\hline
\end{tabular}


TABLE LXV

MEANS FOR EACH SCHOOL BY FACTOR

\begin{tabular}{|c|c|c|c|c|c|c|c|c|c|c|}
\hline & \multirow[b]{2}{*}{ FACTOR } & \multicolumn{9}{|c|}{ SCHOOL } \\
\hline & & $T$ & 2 & 3 & 4 & 5 & 6 & 7 & 8 & 9 \\
\hline 1 & $\begin{array}{l}\text { Rapport with } \\
\text { the Principal }\end{array}$ & 67.478 & 59.828 & 65.778 & 65.391 & 58.000 & 70.357 & 59.136 & 64.947 & 61.682 \\
\hline 2. & $\begin{array}{l}\text { Satisfaction } \\
\text { with Teaching }\end{array}$ & 64.348 & 65.069 & 69.111 & 65.565 & 70.100 & 66.286 & 65.364 & 64.526 & 64.136 \\
\hline 3. & $\begin{array}{l}\text { Rapport Among } \\
\text { Principals }\end{array}$ & 48.913 & 45.931 & 51.889 & 47.696 & 49.100 & 45.929 & 45.500 & 43.474 & 41.727 \\
\hline 4. & $\begin{array}{l}\text { Teacher } \\
\text { Salary }\end{array}$ & 18.652 & 18.724 & 20.000 & 19.826 & 20.000 & 17.929 & 19.318 & 17.211 & 16.364 \\
\hline 5. & $\begin{array}{l}\text { Teacher } \\
\text { Load }\end{array}$ & 30.913 & 34.276 & 30.333 & 36.130 & 33.500 & 31.500 & 35.273 & 33.263 & 32.091 \\
\hline 6 . & $\begin{array}{l}\text { Curriculum } \\
\text { Issues }\end{array}$ & 15.957 & 15.793 & 15.556 & 17.826 & 16.300 & 11.071 & 16.727 & 25.000 & 13.455 \\
\hline 7 . & $\begin{array}{l}\text { Community } \\
\text { Support }\end{array}$ & 11.652 & 12.207 & 15.667 & 13.739 & 16.600 & 13.857 & 13.364 & 13.263 & 11.727 \\
\hline 8. & $\begin{array}{l}\text { Teacher } \\
\text { Status }\end{array}$ & 18.696 & 18.552 & 20.000 & 21.783 & 21.900 & 18.714 & 23.591 & 19.368 & 19.273 \\
\hline 9. & $\begin{array}{l}\text { Facilities/ } \\
\text { Services }\end{array}$ & 16.913 & 17.000 & 16.000 & 17.739 & 14.700 & 14.500 & 17.727 & 15.211 & 14.955 \\
\hline 10 & $\begin{array}{l}\text { Community } \\
\text { Pressures }\end{array}$ & 15.522 & 15.966 & 16.222 & 17.174 & 17.000 & 15.214 & 17.864 & 16.053 & 16.364 \\
\hline
\end{tabular}


TABLE LXVI

MEDIANS FOR EACH SCHOOL. BY FACTOR

\begin{tabular}{|c|c|c|c|c|c|c|c|c|c|c|}
\hline & \multirow[b]{2}{*}{ FACTOR } & \multicolumn{9}{|c|}{ SCHOOL } \\
\hline & & 1 & 2 & 3 & 4 & 5 & 6 & 7 & 8 & 9 \\
\hline 1. & $\begin{array}{l}\text { Rapport with } \\
\text { the Principal }\end{array}$ & 69.000 & 61.750 & 71.000 & 65.125 & 58.500 & 70.500 & 62.000 & 64.750 & 65.500 \\
\hline 2. & $\begin{array}{l}\text { Satisfaction } \\
\text { with Teaching }\end{array}$ & 65.750 & 68.000 & 69.000 & 64.750 & 74.500 & 66.500 & 65.500 & 65.000 & 65.250 \\
\hline 3. & $\begin{array}{l}\text { Rapport Among } \\
\text { Principals }\end{array}$ & 49.000 & 46.417 & 50.250 & 48.000 & 47.500 & 45.500 & 46.500 & 43.000 & 43.167 \\
\hline 4. & $\begin{array}{l}\text { Teacher } \\
\text { Salary }\end{array}$ & 19.000 & 18.667 & 20.000 & 19.400 & 20.833 & 17.500 & 19.750 & 17.000 & 17.500 \\
\hline 5. & $\begin{array}{l}\text { Teacher } \\
\text { Load }\end{array}$ & 32.250 & 34.333 & 30.750 & 36.750 & 33.000 & 30.000 & 36.500 & 33.750 & 33.000 \\
\hline 6. & $\begin{array}{l}\text { Curriculum } \\
\text { Issues }\end{array}$ & 16.625 & 15.875 & 15.000 & 18.600 & 16.500 & 10.500 & 17.500 & 15.000 & 13.500 \\
\hline 7. & $\begin{array}{l}\text { Community } \\
\text { Support }\end{array}$ & 11.600 & 12.143 & 16.750 & 14.000 & 16.500 & 14.000 & 13.500 & 13.000 & 12.500 \\
\hline 8. & $\begin{array}{l}\text { Teacher } \\
\text { Status }\end{array}$ & 18.333 & 17.417 & 19.250 & 20.875 & 21.500 & 18.500 & 23.300 & 19.083 & 18.500 \\
\hline 9. & $\begin{array}{l}\text { Facilities/ } \\
\text { Services }\end{array}$ & 17.000 & 17.111 & 17.750 & 18.333 & 15.000 & 15.831 & 17.833 & 15.800 & 15.000 \\
\hline 10. & $\begin{array}{l}\text { Community } \\
\text { Pressures }\end{array}$ & 16.000 & 16.375 & 15.750 & 17.600 & 16.900 & 15.500 & 18.000 & 15.375 & 16.000 \\
\hline
\end{tabular}


TABLE LXVII

PERCENTAGE DISTRIBUTION OF FACULTY MEDIANS

BY FACTORS IN THE NORMATIVE SAMPLE*

\begin{tabular}{llllll}
\hline \multicolumn{1}{l}{ FACTOR } & 90 & 75 & 50 & 25 & 10 \\
\hline 1. Rapport with the Principal & 3.64 & 3.36 & 3.17 & 2.86 & 2.54 \\
2. Satisfaction with Teaching & 3.72 & 3.64 & 3.56 & 3.43 & 3.31 \\
3. Rapport Among Principals & 3.60 & 3.35 & 3.21 & 3.09 & 2.90 \\
4. Teacher Salary & 3.23 & 2.91 & 2.53 & 2.12 & 1.82 \\
5. Teacher Load & 3.68 & 3.58 & 3.39 & 3.18 & 3.02 \\
6. Curriculum Issues & 3.39 & 3.13 & 2.90 & 2.64 & 2.28 \\
7. Community Support & 3.18 & 2.97 & 2.78 & 2.62 & 2.43 \\
8. Teacher Status & 3.42 & 3.08 & 2.83 & 2.52 & 2.14 \\
9. Facilities/Services & 3.56 & 3.19 & 2.86 & 2.44 & 1.96 \\
10. Community Pressures & 3.72 & 3.59 & 3.44 & 3.24 & 3.07 \\
\hline
\end{tabular}

*Normative sample from Bentiey and Rempel (1980), p. 9. 
TABLE LXVIII

FACULTY MEDIANS FOR THE SAMPLE BY FACTORS

\begin{tabular}{lll}
\hline FACTOR & MEDIAN FOR ALL RESPONSES & MEDIAN \\
\hline 1. $\begin{array}{l}\text { Rapport with } \\
\text { the Principal }\end{array}$ & 65.350 & 3.267 \\
2. Satisfaction & & \\
$\begin{array}{l}\text { with Teaching } \\
\text { 3. Rapport Among }\end{array}$ & 66.143 & 3.307 \\
$\begin{array}{l}\text { Teachers } \\
\text { 4. Teacher Salary }\end{array}$ & 46.531 & 3.324 \\
5. Teacher Load & 18.667 & 2.667 \\
6. Curriculum Issues & 33.769 & 3.069 \\
7. Teacher Status & 15.941 & 3.188 \\
8. Community Support & 19.615 & 2.452 \\
9. School Facilities/ & 13.179 & 2.636 \\
Services & 16.817 & 3.363 \\
10. Community Pressures & 13.179 & 2.636 \\
\hline
\end{tabular}


TABLE LXIX

TEACHER SALARY MEDIANS IN RELATION

TO NORMATIVE SAMPLE

\begin{tabular}{ccccc}
\hline RESPONSE & $\begin{array}{c}\text { NORM MEDIANS } \\
10 t h\end{array}$ & $\begin{array}{c}\text { FOR } \\
50 \mathrm{th}\end{array}$ & $\begin{array}{c}\text { PERCENTILES } \\
90 \mathrm{th}\end{array}$ & SAMPLE MEDIANS \\
\hline 4 & 1.5 & 2.4 & 3.2 & 2.067 \\
9 & 1.2 & 2.3 & 3.3 & 2.877 \\
32 & 1.4 & 2.4 & 3.3 & 2.721 \\
36 & 1.8 & 2.6 & 3.3 & 2.753 \\
39 & 2.3 & 2.9 & 3.4 & 3.402 \\
65 & 1.3 & 1.9 & 2.6 & 1.864 \\
75 & 1.6 & 2.8 & 3.6 & 3.396 \\
\hline
\end{tabular}




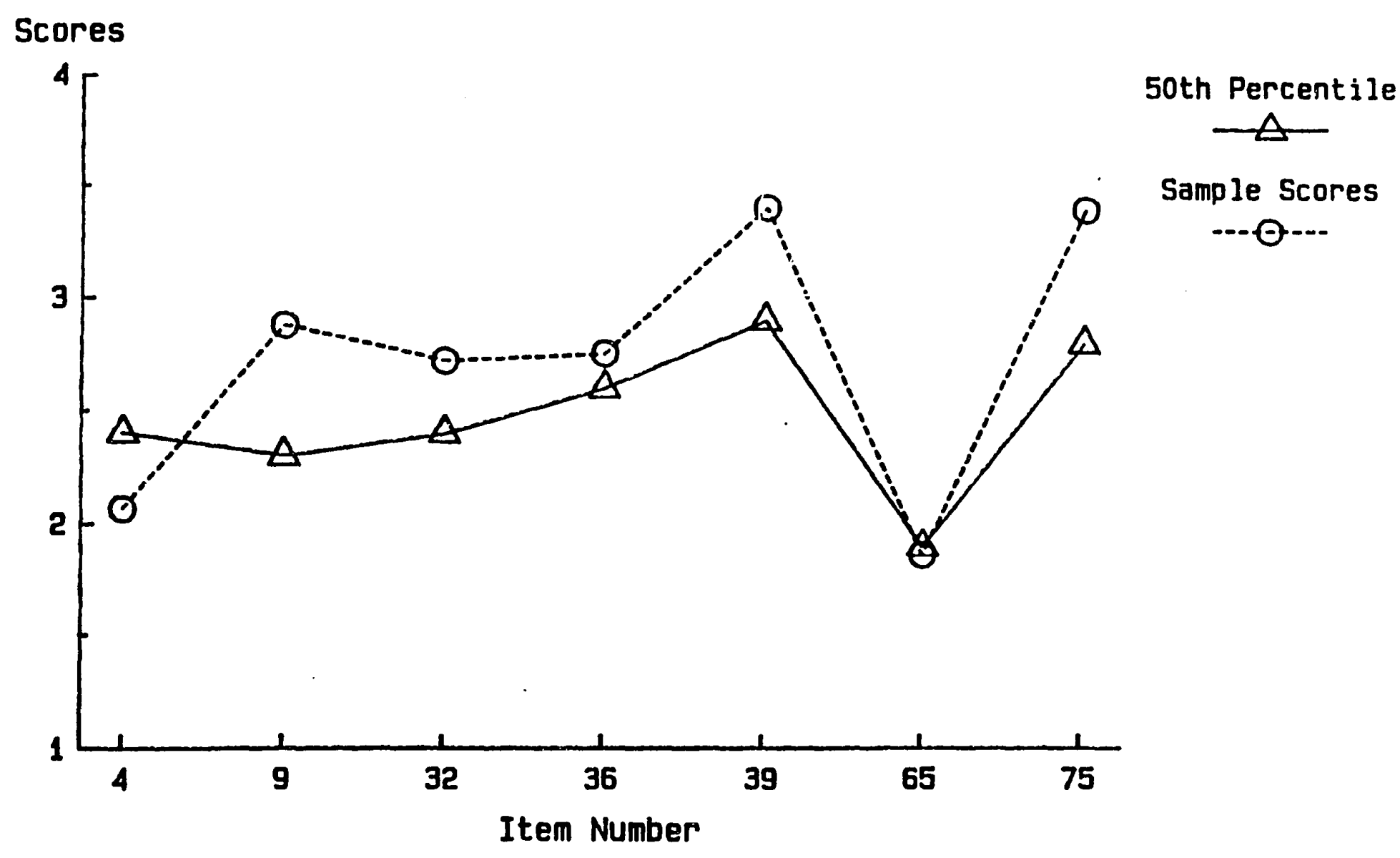

Figure 16. Median teacher salary responses by item. 
TABLE LXX

TEACHER LOAD MEDIANS IN RELATION

TO NORMATIVE SAMPLE

\begin{tabular}{ccccc}
\hline RESPONSE & $\begin{array}{c}\text { NORM MEDIANS } \\
10 \mathrm{th}\end{array}$ & $\begin{array}{c}\text { FOR } \\
50 \mathrm{th}\end{array}$ & $\begin{array}{c}\text { PERCENTILES } \\
90 \mathrm{th}\end{array}$ & SAMPLE MEDIANS \\
\hline 1 & 1.5 & 2.3 & 3.3 & 2.246 \\
6 & 2.3 & 3.2 & 3.7 & 3.243 \\
8 & 3.3 & 3.7 & 3.8 & 3.434 \\
10 & 2.9 & 3.5 & 3.7 & 3.338 \\
11 & 3.0 & 3.6 & 3.8 & 3.581 \\
14 & 2.6 & 3.1 & 3.6 & 2.782 \\
31 & 2.8 & 3.4 & 3.8 & 3.317 \\
34 & 2.9 & 3.2 & 3.6 & 2.993 \\
40 & 2.9 & 3.4 & 3.8 & 3.373 \\
42 & 3.0 & 3.5 & 3.8 & 3.506 \\
45 & 2.9 & 3.3 & 3.7 & 3.225 \\
\hline
\end{tabular}



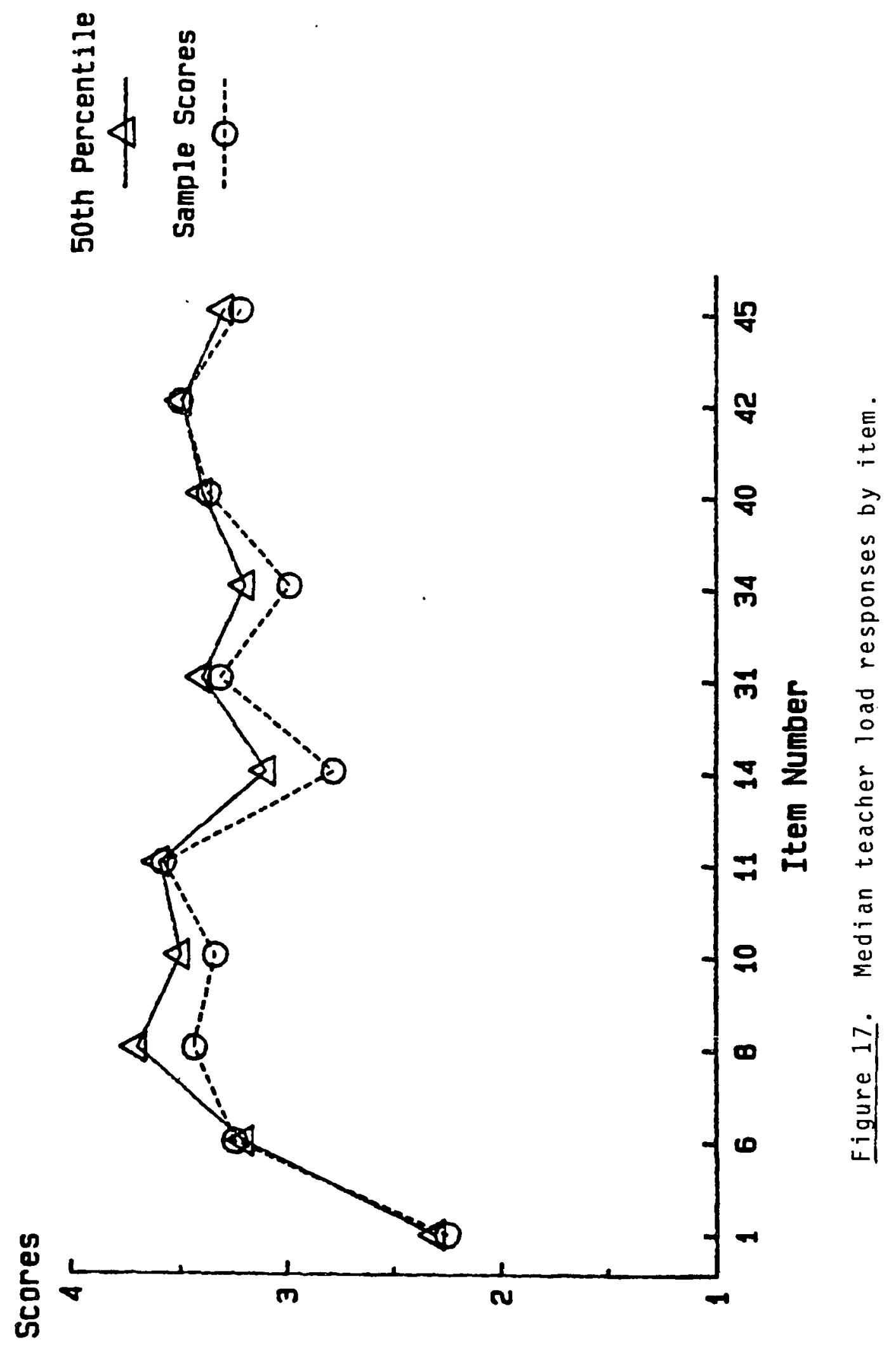
TABLE LXXI

CURRICULUM ISSUES SAMPLE MEDIANS IN

RELATION TO NORMATIVE SAMPLE

\begin{tabular}{ccccc}
\hline RESPONSE & $\begin{array}{c}\text { NORM MEDIANS } \\
\text { 10th } \mathrm{fOR}\end{array}$ & $\begin{array}{c}\text { PERCENTILES } \\
50 \mathrm{th}\end{array}$ & $\begin{array}{c}\text { SAMPLE MEDIANS } \\
90 \mathrm{th}\end{array}$ & \\
\hline 17 & 2.0 & 3.0 & 3.7 & 3.475 \\
20 & 2.1 & 2.9 & 3.5 & 3.047 \\
25 & 1.5 & 2.6 & 3.2 & 3.000 \\
79 & 2.4 & 2.9 & 3.5 & 3.313 \\
88 & 2.4 & 2.9 & 3.2 & 3.131 \\
\hline
\end{tabular}




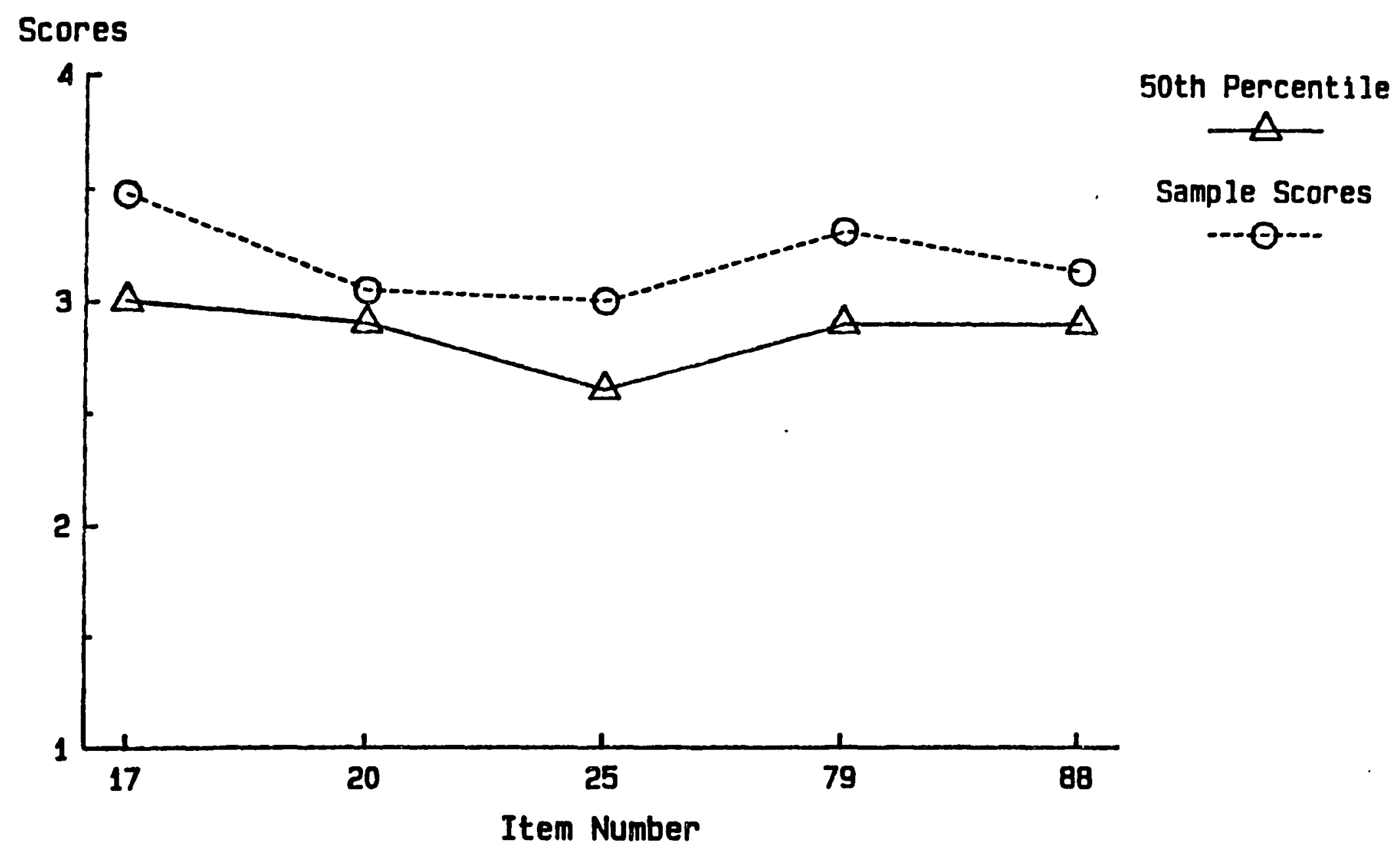

Figure 18. Median curriculum issues responses by item. 
TABLE LXXII

COMMUNITY SUPPORT FOR EDUCATION MEDIANS IN RELATION TO NORMATIVE SAMPLE

\begin{tabular}{ccccc}
\hline RESPONSE & $\begin{array}{c}\text { NORM MEDIANS } \\
\text { 10th }\end{array}$ & $\begin{array}{c}\text { FOR } \\
50 \mathrm{th}\end{array}$ & $\begin{array}{c}\text { PERCENTILES } \\
\text { 90th }\end{array}$ & $\begin{array}{c}\text { SAMPLE MEDIANS } \\
n=171\end{array}$ \\
\hline 66 & 1.7 & 2.3 & 3.2 & 2.352 \\
67 & 2.3 & 3.1 & 3.6 & 3.077 \\
94 & 1.9 & 2.7 & 3.3 & 2.625 \\
96 & 2.5 & 2.9 & 3.3 & 2.820 \\
97 & 2.1 & 2.8 & 3.6 & 2.638 \\
\hline
\end{tabular}




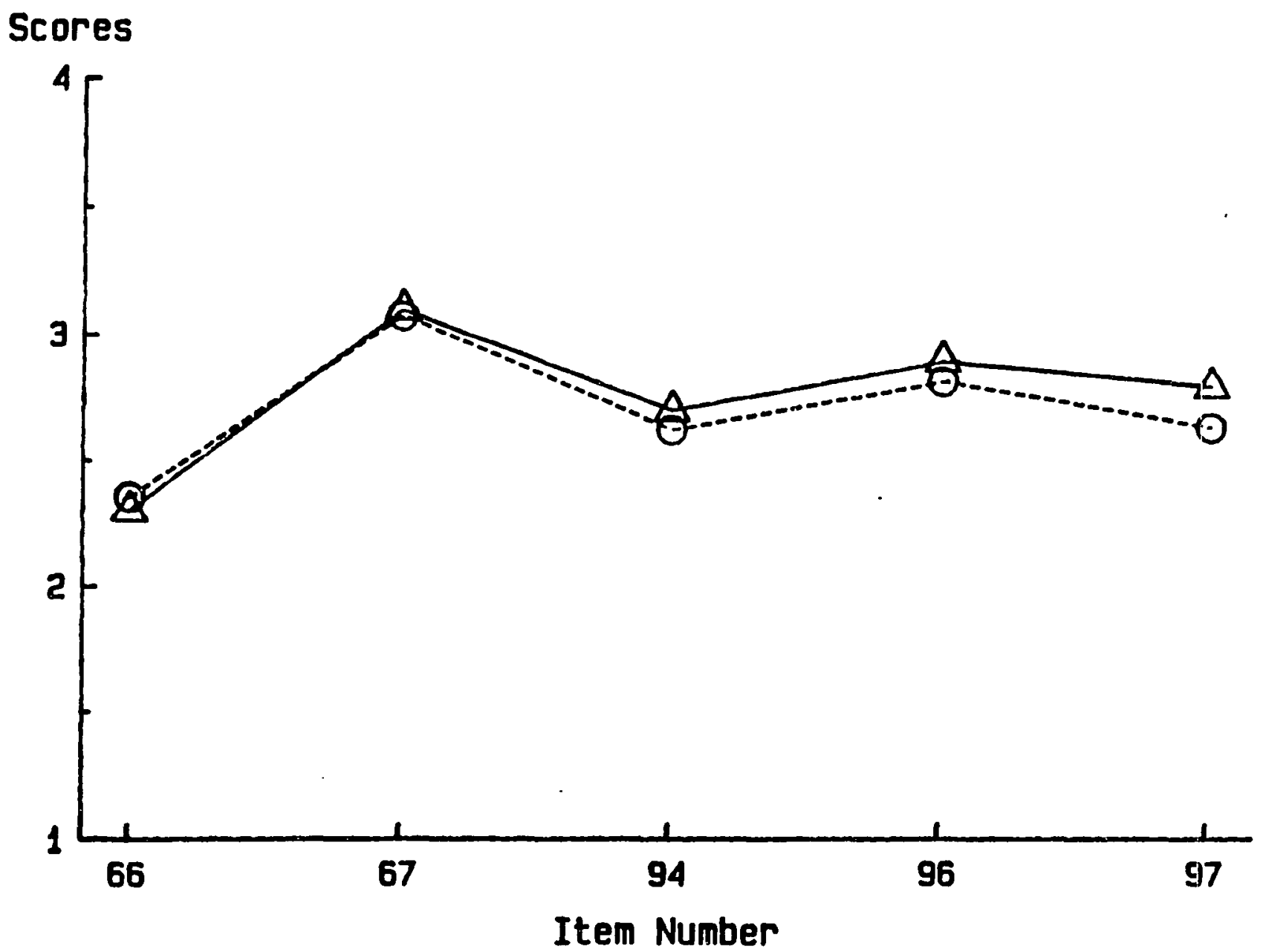

50th Percentile

Sample Scores $---\theta^{--.-}$

Figure 19. Median community support for education responses by item.

$\stackrel{\sim}{\rightleftarrows}$ 
TABLE LXXIII

SCHOOL FACILITIES AND SERVICES MEDIANS

IN RELATION TO NORMATIVE SAMPLE

\begin{tabular}{ccccc}
\hline RESPONSE & $\begin{array}{c}\text { NORM MEDIANS } \\
10 \mathrm{th}\end{array}$ & $\begin{array}{c}\text { FOR } \\
50 \mathrm{th}\end{array}$ & $\begin{array}{c}\text { PERCENTILES } \\
90 \mathrm{th}\end{array}$ & SAMPLE MEDIANS \\
\hline 16 & 1.5 & 2.9 & 3.7 & 3.356 \\
21 & 2.1 & 2.9 & 3.5 & 3.099 \\
49 & 2.1 & 3.3 & 3.8 & 3.254 \\
57 & 1.4 & 2.1 & 3.3 & 3.219 \\
59 & 1.9 & 2.9 & 3.6 & 3.609 \\
\hline
\end{tabular}




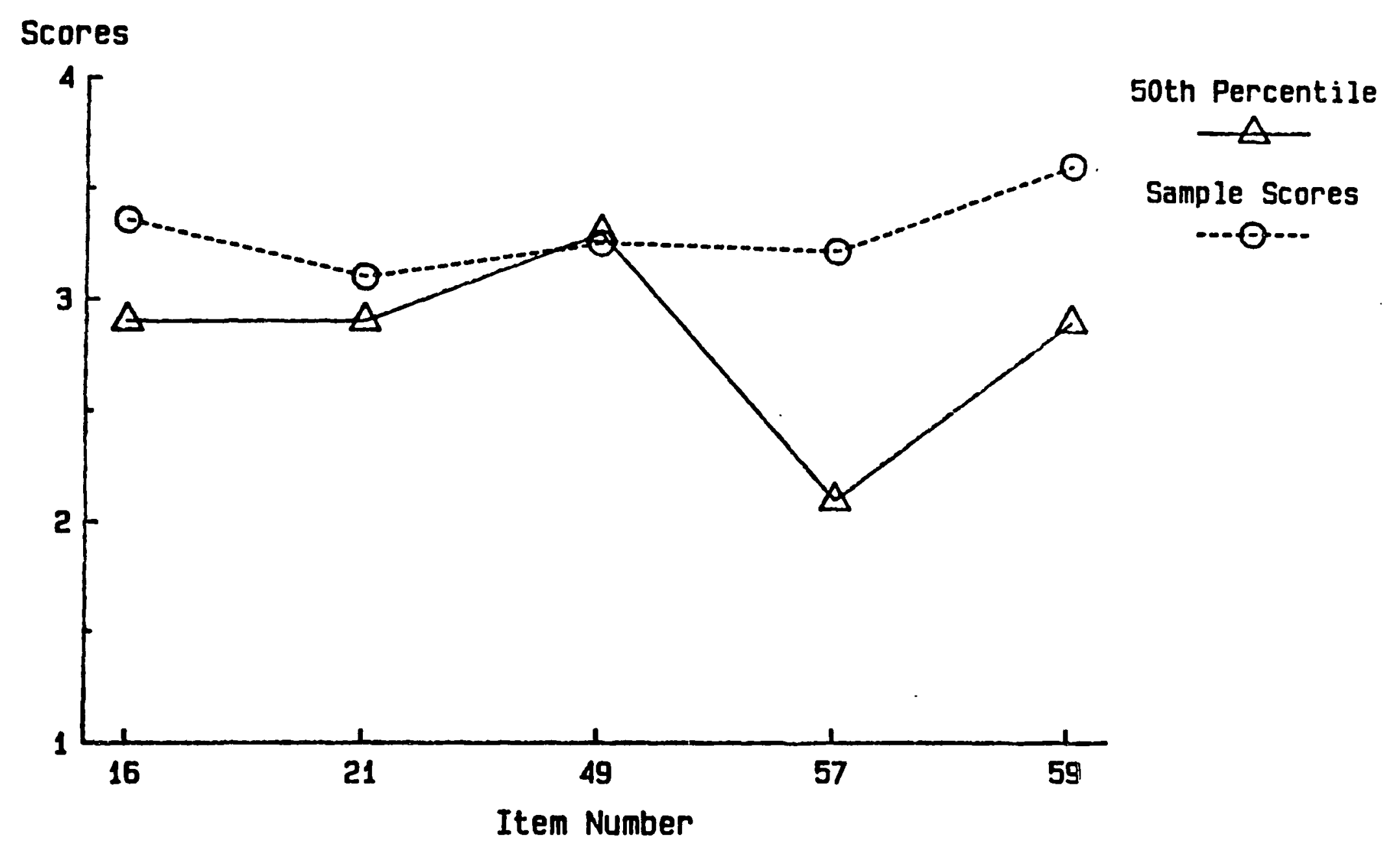

Figure 20. Median school facilities and services responses by item. 
TABLE LXXIV

COMMUNITY PRESSURES MEDIANS IN RELATION TO NORMATIVE SAMPLE

\begin{tabular}{ccccc}
\hline RESPONSE & \multicolumn{2}{c}{$\begin{array}{c}\text { NORM MEDIANS FOR } \\
\text { 10th } \mathrm{h}\end{array}$} & $\begin{array}{c}\text { PERCENTILES } \\
\text { 50th }\end{array}$ & $\begin{array}{c}\text { SAMPLE MEDIANS } \\
\text { 90th }\end{array}$ \\
\hline 81 & 3.0 & 3.4 & 3.7 & 3.292 \\
85 & 3.0 & 3.5 & 3.8 & 3.775 \\
91 & 2.2 & 2.9 & 3.4 & 2.738 \\
98 & 3.0 & 3.4 & 3.7 & 3.506 \\
99 & 3.4 & 3.7 & 3.8 & 3.693 \\
\hline
\end{tabular}




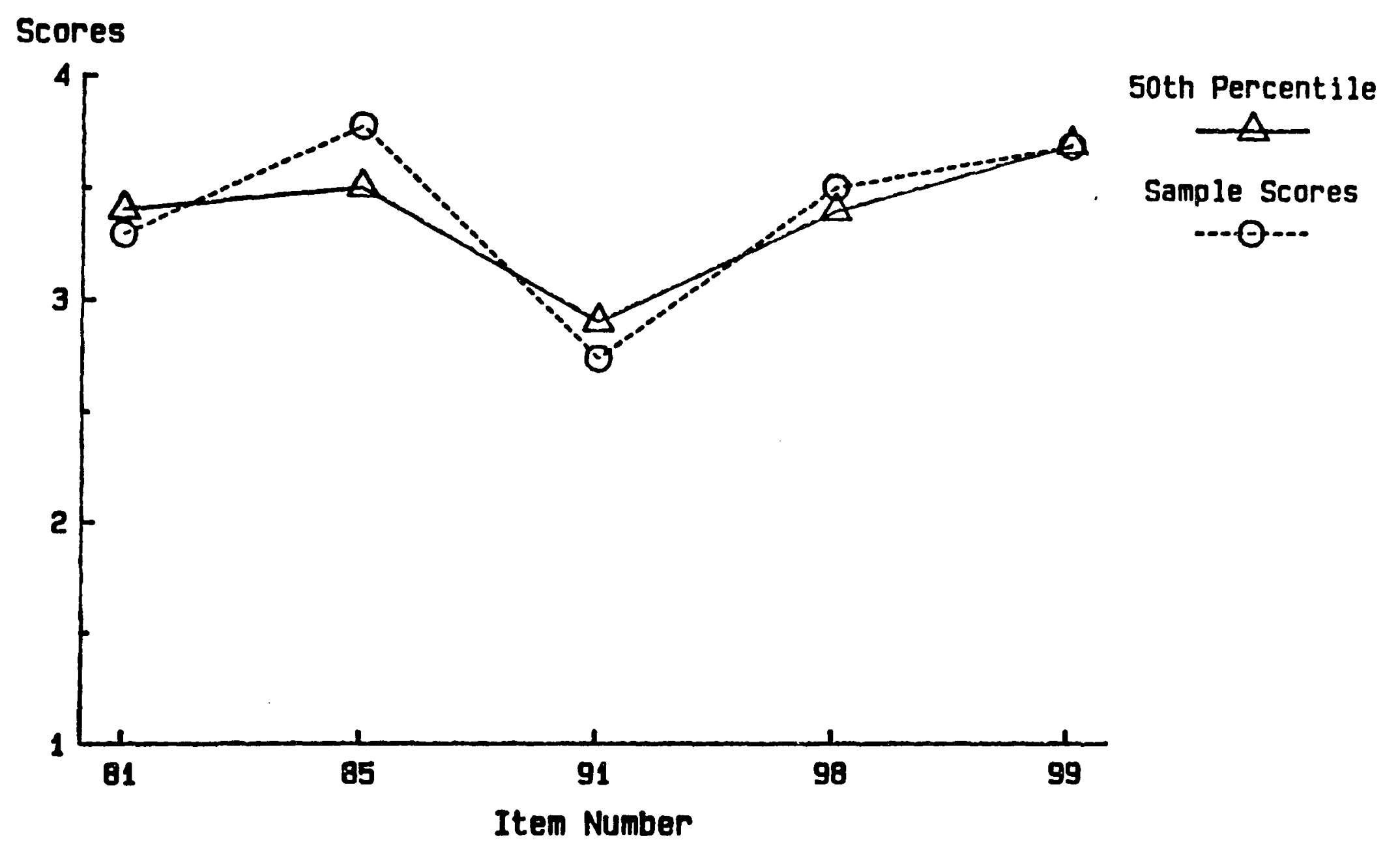

Figure 21. Median community pressures responses by item. 